\title{
WestVirginiaUniversity
}

THE RESEARCH REPOSITORY @ WVU

Graduate Theses, Dissertations, and Problem Reports

2008

\section{Characterization of nickel-substituted hexaaluminate catalysts}

Jason C. Hissam

West Virginia University

Follow this and additional works at: https://researchrepository.wvu.edu/etd

\section{Recommended Citation}

Hissam, Jason C., "Characterization of nickel-substituted hexaaluminate catalysts" (2008). Graduate

Theses, Dissertations, and Problem Reports. 1977.

https://researchrepository.wvu.edu/etd/1977

This Thesis is protected by copyright and/or related rights. It has been brought to you by the The Research Repository @ WVU with permission from the rights-holder(s). You are free to use this Thesis in any way that is permitted by the copyright and related rights legislation that applies to your use. For other uses you must obtain permission from the rights-holder(s) directly, unless additional rights are indicated by a Creative Commons license in the record and/ or on the work itself. This Thesis has been accepted for inclusion in WVU Graduate Theses, Dissertations, and Problem Reports collection by an authorized administrator of The Research Repository @ WVU. For more information, please contact researchrepository@mail.wvu.edu. 


\title{
CHARACTERIZATION OF NICKEL-SUBSTITUTED \\ HEXAALUMINATE CATALYSTS
}

by

\author{
Jason C. Hissam
}

Thesis submitted to the College of Engineering and Mineral Resources at West Virginia University

in partial fulfillment of the requirements

for the degree of

Master of Science

in

Chemical Engineering

Submitted for the approval of:

Edwin L. Kugler, Ph.D., Chair

Dady B. Dadyburjor, Ph.D.

John W. Zondlo, Ph.D.

Department of Chemical Engineering

Morgantown, West Virginia

2008

Keywords: hexaaluminate, catalyst, Unit-cell refinement (UCR), X-ray diffraction (XRD), Fourier Transform Infrared (FT-IR) spectroscopy, nickel (Ni) 


\section{ABSTRACT \\ Characterization of Nickel-substituted Hexaaluminate Catalysts Jason C. Hissam}

A characterization study was performed on two series of hexaaluminate catalysts of the form $\mathrm{M}_{\mathrm{I}}\left(\mathrm{M}_{\mathrm{II}}\right)_{\mathrm{x}} \mathrm{Al}_{12-\mathrm{x}} \mathrm{O}_{19-\delta}$; where $\mathrm{M}_{\mathrm{I}}$ refers to the mirror cation $\left(\mathrm{M}_{\mathrm{I}}=\mathrm{Ba}, \mathrm{Sr}, \mathrm{La}\right)$ and $M_{I I}$ to the cation $\left(M_{I I}=N i\right)$ substituted into the lattice. The first series was synthesized for comparison of different mirror cations while holding the Ni substitution level constant at $\mathrm{x}=0.4$. The second series was developed with the same mirror cation of $\mathrm{Ba}$, but varied $\mathrm{x}$, the level of Ni substitution. Experiments were conducted by means of the following characterization techniques: scanning electron microscopy (SEM), unit-cell refinement (UCR), in situ temperature-programmed reduction and X-ray diffraction (TPR-XRD) and Fourier-transform infrared (FT-IR) spectroscopy.

UCR showed that Ni has been incorporated into the hexaaluminate lattice during synthesis. Increasing the $\mathrm{Ni}$ substitution level results in an increase in the $a$ and $b$ parameters and a decrease in the $c$ direction. The overall volume of the unit-cell was found to increase with higher Ni substitution level. In situ TPR-XRD studies with La and $\mathrm{Sr}$ hexaaluminates have shown that $\mathrm{Ni}$ in the lattice upon reduction with $\mathrm{H}_{2}$ turns into metallic $\mathrm{Ni}^{0}$ on the hexaaluminate surface of the crystal. Experiments with $\mathrm{Ba}$ hexaaluminates were mostly inconclusive due to the hexaaluminate diffraction pattern having intense peaks in the same positions as $\mathrm{Ni}^{0}$ metal so that the hexaaluminate pattern masks the appearance of $\mathrm{Ni}^{0}$ metal peaks. Fourier-transform infrared spectroscopy of the absorption of $\mathrm{CO}$ on reduced catalysts was performed to distinguish between $\mathrm{Ni}^{+2}$ ions and $\mathrm{Ni}^{0}$ metal species on the hexaaluminate surfaces. However, the analysis of the FT-IR spectra provided no evidence for $\mathrm{CO}$ adsorbed on either $\mathrm{Ni}^{+2}$ ions or metallic $\mathrm{Ni}^{0}$ on the hexaaluminate surface. During exposure of $\mathrm{CO}$, there was the appearance of multiple peaks that indicate the presence of gas phase $\mathrm{CO}$ and $\mathrm{CO}_{2}$ molecules as well as the formation of carboxylates and carbonates. Upon evacuation of the experimental chamber, the only remaining peaks belonged to those of the appropriate mirror cation carbonate. 


\section{Acknowledgements}

I would like to express my eternal gratitude toward my advisor, Dr. Kugler, for his continued help, guidance and advice throughout the duration of this project. I would also like to thank Dr. Dadyburjor and Dr. Zondlo for their advice and supporting roles as members of my committee. I would also like to thank Jim Hall, Linda Rogers and Bonita Helmick for their various levels of assistance throughout my time in the West Virginia University Department of Chemical Engineering.

I am grateful to the U.S. Department of Energy for their financial support of this project under DOE prime contract DE-AC26-04NT41817.606.01.06. I would like to lay emphasis on thanks to Dr. Todd Gardner for his role of synthesizing the catalysts and performing initial studies on them. I would also like to thank Daniel Haynes and other researchers at the National Energy Technology Laboratory for their advice and assistance in running experiments at NETL. Thanks are to be given to Dr. Jonathan Hanson at Brookhaven National Laboratory for his assistance in performing X-ray diffraction experiments at BNL.

I would like to thank my fellow graduate students in the catalysis and reaction engineering group at WVU; Ashish Bambal, Mayuri Mukka, Ramanjaneyulu Katta and Joshua Welshans, for their friendship, support, ideas and assistance in fabricating and running experiments in the laboratory. I am also grateful to Adam Finniss, Steve Markovich, Christopher Yurchick, Lloyd Ford and the rest of the graduate students for making my time as a graduate student enjoyable.

Special thanks are to be directed to my family; Dad, Mom, Cheryl, Lisa and the others too numerous to list, as well as my dear friends, Abha Saddawi and Matthew Perkowski, for encouraging me to reach the next level and eagerly giving me the occasional boost when it was desperately needed. 


\section{Table of Contents}

Abstract

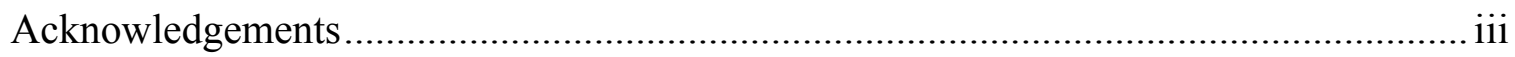

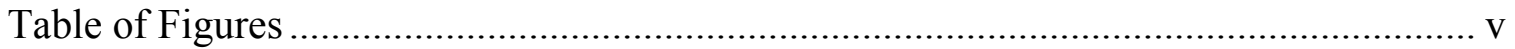

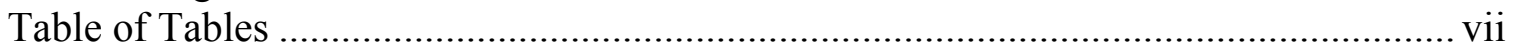

Chapter 1: Introduction ............................................................................................. 1

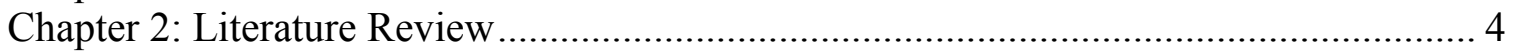

2.1 Hexaaluminate Structure and Properties........................................................... 4

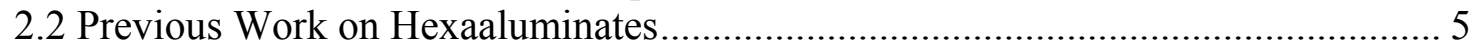

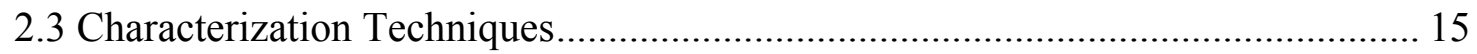

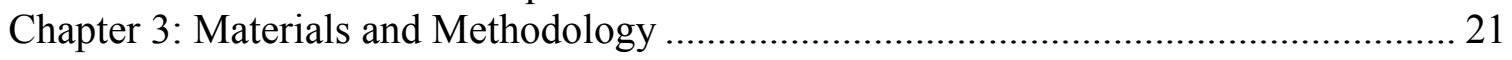

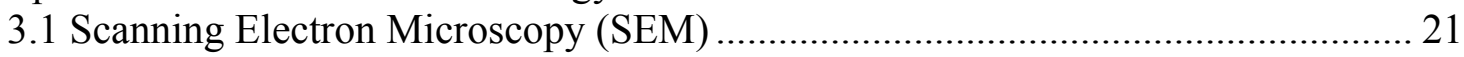

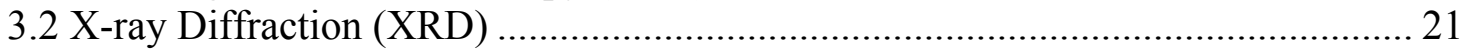

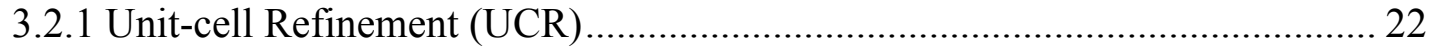

3.2.2 In situ Temperature-programmed Reduction and X-ray Diffraction (TPR-

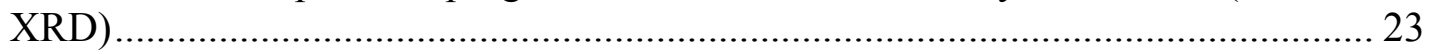

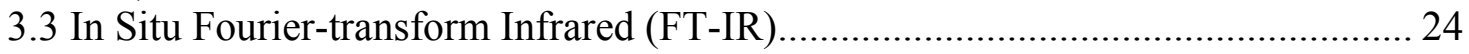

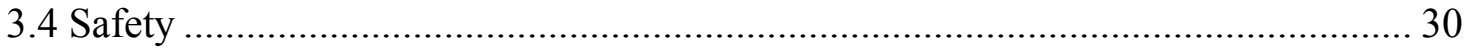

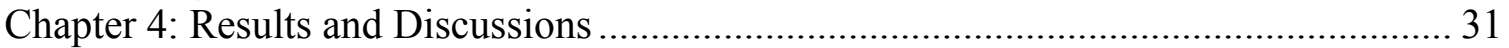

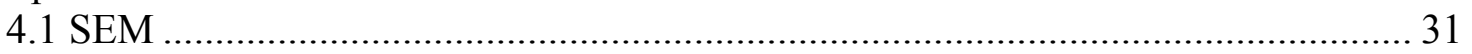

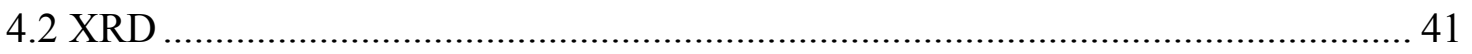

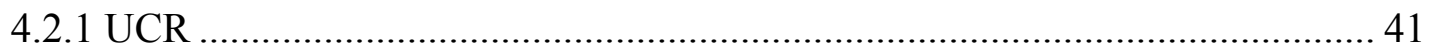

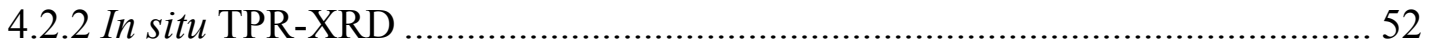

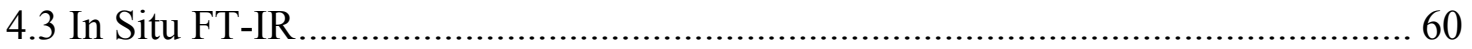

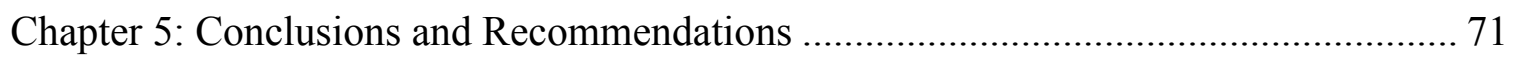

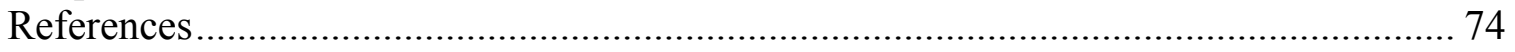

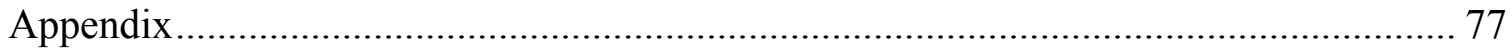

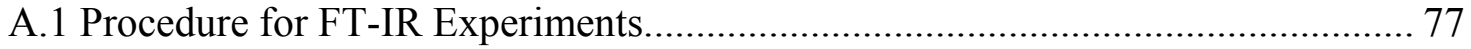




\section{Table of Figures}

Figure 1: Ideal unit-cell structures of hexaaluminates (7) ............................................. 4

Figure 2: $\mathrm{H}_{2}$ consumption curves illustrating the reduction temperatures of ................... 12

Figure 3: Temperature programmed oxidation of $\mathrm{CH}_{4}$ over quartz (21) ........................ 13

Figure 4: Temperature programmed oxidation of $\mathrm{CH}_{4}$ over $\mathrm{BaNi}_{0.8} \mathrm{Al}_{11.2} \mathrm{O}_{19.6}(21) \ldots \ldots . .14$

Figure 5: Schematic representation of the geometry of the X7B beamline experimental

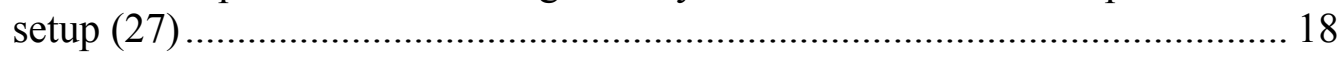

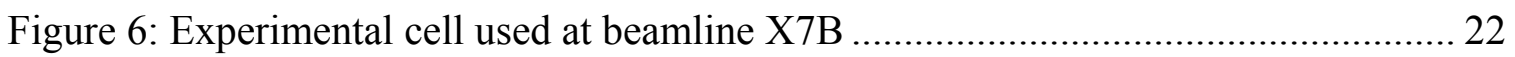

Figure 7: Thermo Nicolet Nexus 670 infrared spectrometer setup................................... 25

Figure 8: DRIFTS dual environmental chamber for smart collector............................... 26

Figure 9: Process flow diagram of setup of the gas feed inlet of dual environmental

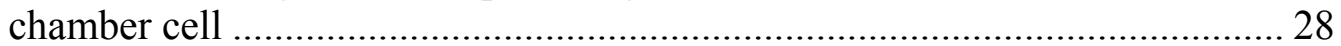

Figure 10: Setup of the gas feed inlet of dual environmental chamber cell .................... 29

Figure 11: SEM image of calcined $\mathrm{LaNi}_{0.4} \mathrm{Al}_{11.6} \mathrm{O}_{19}$ [35] .......................................... 32

Figure 12: SEM image of calcined $\mathrm{SrNi}_{0.4} \mathrm{Al}_{11.6} \mathrm{O}_{19}$ [52] ........................................... 33

Figure 13: SEM image of calcined $\mathrm{BaNi}_{0.4} \mathrm{Al}_{11.6} \mathrm{O}_{18.8}$ [75]........................................ 34

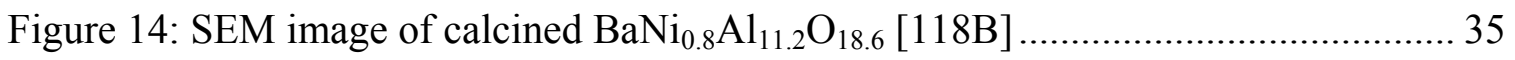

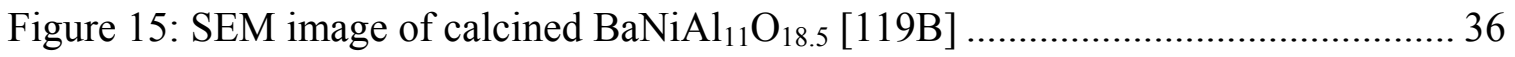

Figure 16: SEM image of calcined $\mathrm{BaAl}_{12} \mathrm{O}_{19}[38 \mathrm{C}]$.................................................... 37

Figure 17: SEM image of blue particle of $\mathrm{BaNiAl}_{11} \mathrm{O}_{18.5}$ [119B-blue] after $\mathrm{CH}_{4} \mathrm{PO}_{x} \ldots . .39$

Figure 18: SEM image of gray particle of $\mathrm{BaNiAl}_{11} \mathrm{O}_{18.5}$ [119B-gray] after $\mathrm{CH}_{4} \mathrm{PO}_{\mathrm{x}} \ldots . .40$

Figure 19: X-ray diffraction pattern of fresh $\mathrm{LaNi}_{0.4} \mathrm{Al}_{11.6} \mathrm{O}_{19}$ [35] ................................. 42

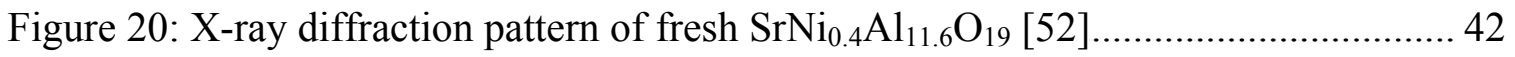

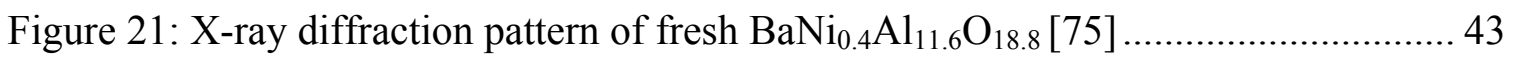

Figure 22: $a$ and $b$ lattice parameters of fresh $\mathrm{Ba} \mathrm{Ni}$-substituted hexaaluminates............ 45

Figure 23: $c$ lattice parameters of fresh Ba Ni-substituted hexaaluminates...................... 46

Figure 24: Cell volumes of fresh Ni-substituted Ba hexaaluminates ................................ 46

Figure 25: $a$ and $b$ lattice parameters of used gray Ni-substituted Ba hexaaluminates .... 48

Figure 26: $c$ lattice parameters of used gray Ni-substituted Ba hexaaluminates .............. 48

Figure 27: Cell volumes of used gray Ni-substituted Ba hexaaluminates ........................ 49

Figure 28: Compilation of $a$ and $b$ unit-cell refinement data of both fresh and used

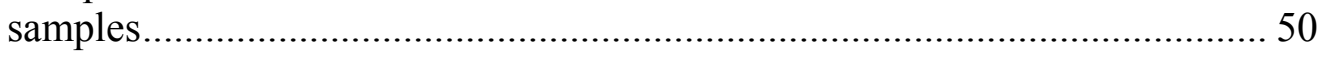

Figure 29: Compilation of $c$ unit-cell refinement data of both fresh and used samples ... 50

Figure 30: Compilation of unit-cell refinement of cell volume data of both fresh

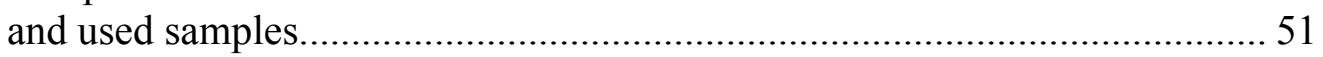

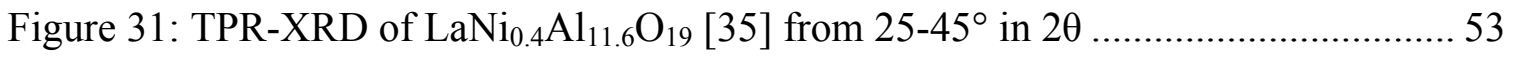


Figure 32: Detail of TPR-XRD of $\mathrm{LaNi}_{0.4} \mathrm{Al}_{11.6} \mathrm{O}_{19}$ [35] from $25-35^{\circ}$ in $2 \theta$................... 54

Figure 33: Detail of TPR-XRD of $\mathrm{LaNi}_{0.4} \mathrm{Al}_{11.6} \mathrm{O}_{19}$ [35] from $35-45^{\circ}$ in $2 \theta$................... 55

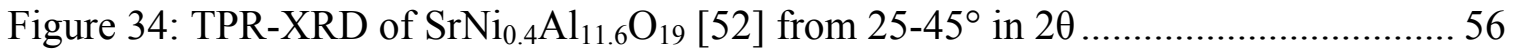

Figure 35: Detail of TPR-XRD of $\mathrm{SrNi}_{0.4} \mathrm{Al}_{11.6} \mathrm{O}_{19}$ [52] from $25-35^{\circ}$ in $2 \theta \ldots \ldots \ldots \ldots \ldots \ldots . . . .56$

Figure 36: Detail of TPR-XRD of $\mathrm{SrNi}_{0.4} \mathrm{Al}_{11.6} \mathrm{O}_{19}$ [52] from $35-45^{\circ}$ in $2 \theta$.................... 57

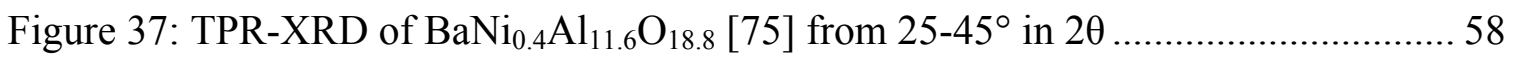

Figure 38: TPR-XRD of $\mathrm{BaNiAl}_{11} \mathrm{O}_{18.5}$ [119B] from $25-45^{\circ}$ in $2 \theta$............................... 59

Figure 39: Detail of TPR-XRD of $\mathrm{BaNiAl}_{11} \mathrm{O}_{18.5}$ [119B] from $25-35^{\circ}$ in $2 \theta$................. 59

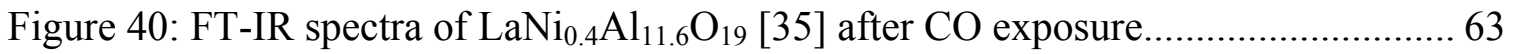

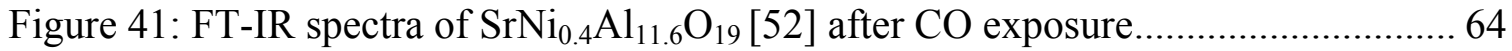

Figure 42: FT-IR spectra of $\mathrm{BaNi}_{0.4} \mathrm{Al}_{11.6} \mathrm{O}_{18.8}$ [75] after $\mathrm{CO}$ exposure ........................ 65

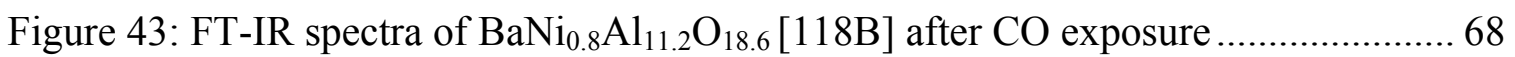

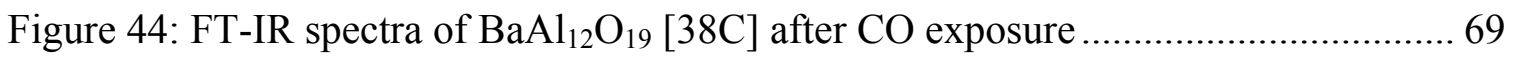




\section{Table of Tables}

Table 1: Surface Area, Dispersion and Bulk Surface Ni Concentration of Ni-substituted

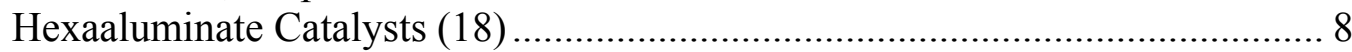

Table 2: Ni-Substituted Hexaaluminates Synthesis Conditions ........................................ 11

Table 3: ICDD Crystal Lattice Dimensions of Baseline Patterns....................................... 41

Table 4: Crystal Lattice Parameters of Fresh Ni-Substituted La, Sr and Ba

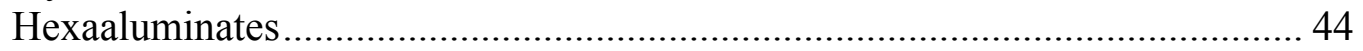

Table 5: Crystal Lattice Parameters of Fresh Ni-substituted Ba Hexaaluminates............ 45

Table 6: Crystal Lattice Parameters of Gray Ni-substituted Ba Hexaaluminates............. 47

Table 7: Positions of $\mathrm{Ni}^{0}$ Metal Peaks at Wavelength of $0.9225 \AA$................................... 52

Table 8: Results of CO Pulse Chemisorptions of $\mathrm{Ni}^{0}$ Metal in $\mathrm{La}, \mathrm{Sr}$ and $\mathrm{Ba} \mathrm{Ni}-$

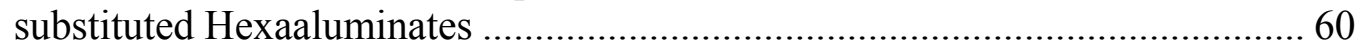

Table 9: Position of Infrared Bands for CO on Adsorbed Ni Species................................. 61

Table 10: Position of Infrared Bands for CO on Adsorbed Non-Ni Species..................... 61 


\section{Chapter 1: Introduction}

Energy conservation and pollution prevention are of the utmost importance in order to ensure the stability of future energy requirements of the United States of America, as well as the rest of the world. One significant source of excessive fuel consumption and emissions is a result of the idling of heavy-duty diesel engines, particularly in long haul trucks. In order to confront this problem, the Environmental Protection Agency (EPA) established the SmartWay Transport Partnership, a collaborative program between the EPA and the freight industry with the goals of increasing energy efficiency and reducing air pollution and greenhouse gases (1).

Long-haul truck drivers idle their engines during periods of rest to provide heat or air-conditioning to the cab, to prevent the engine block from freezing in cold weather, and to maintain battery voltage for the use of electrical appliances both inside and outside of the truck cab. Idling engines operate at low levels of efficiency and lead to excess fuel consumption, emissions and wear and tear on the engine. Detailed data on idling is not available, but industry sources have provided rough estimates of its frequency (1). Truck driver surveys have indicated periods of rest in the range of six to eight hours per day, operating over 300 days per year. For the 500,000 to 1,000,000 trucks matching this description, it is estimated that $30-40 \%$ of the total engine operating time is due to idling. Over 960 million gallons of diesel fuel are consumed through long-duration truck idling annually. The resulting emissions are an estimated 11 million tons of carbon dioxide, 180,000 tons of nitrogen oxides, and 5,000 tons of particulate matter.

There are several alternatives to idling that have been investigated and each method has strengths and weaknesses $(2 ; 3)$. The most feasible and cost-effective technology to reduce diesel fuel consumption is to mount an auxiliary power unit (APU) on the truck cab (2). While the main engine is disengaged, the APU supplies heating and air-conditioning of the sleeper cab, heat for engine startup and power for electrical appliances.

According to Stodolsky and others (2), conventional APUs consist of a small internal combustion engine equipped with a generator to provide energy for heating and cooling of the cab and powering appliances (2). For air-conditioning, the APU can be a power source for the existing air-conditioning system of the truck or an additional 
electrically powered air-conditioning unit can be installed in the sleeper area. Comparison studies conducted at the Aberdeen Test Center and the Oak Ridge National Laboratory indicate that the installation of an APU gives fuel savings (and $\mathrm{CO}_{2}$ reduction) on the order of $60-85 \%, 50-97 \%$ reductions in $\mathrm{NO}_{\mathrm{x}}, \mathrm{CO}$ and hydrocarbons and particulate matter ranged from a mass increase of $20 \%$ to reduction of $95 \%$ depending on the age and model of the truck $(2 ; 4)$. Although current APUs have been proven to provide the solutions the EPA and industry are seeking, the units are heavy, noisy, costly and require an external supply of water for cooling purposes.

A promising alternative to the conventional APU's is the diesel-powered solid oxide fuel cell (SOFC). The SOFC-based APU can combine the functions of existing APU technology with the advantages of fuel cells, such as fuel flexibility, low or no maintenance, high efficiency and silent operation. Jain et al. (3) describe a typical SOFC-based APU as having a single air compressor that provides air for reformer operation and cathode requirements. The anode recycle stream and water generated from unreacted anode tail-gas captured in a tail-gas burner, supply water for the reformer and decrease the need for an on-board supply of water.

Complementary to the SmartWay Transport Partnership of EPA mentioned earlier, the U.S. Department of Energy (DOE) has sponsored the Solid State Energy Conversion Alliance (SECA), forming partnerships between the U.S. government, industry, universities, and other research organizations in order to promote the development of environmentally friendly SOFC for a variety of energy needs (5). As part of the SECA program, the National Energy Technology Laboratory (NETL) of the DOE is working on the development of a new class of structural oxide catalysts based on hexaaluminate architecture for use with diesel-fueled APUs (6). The hexaaluminate catalysts are of the form $\mathrm{M}_{\mathrm{I}}\left(\mathrm{M}_{\mathrm{II}}\right)_{\mathrm{x}} \mathrm{Al}_{12-\mathrm{x}} \mathrm{O}_{19-\delta}$, where $\mathrm{M}_{\mathrm{I}}$ refers to the cation $\left(\mathrm{M}_{\mathrm{I}}=\mathrm{Ba}, \mathrm{Sr}\right.$, La) and $\mathrm{M}_{\mathrm{II}}$ to the cation $\left(\mathrm{M}_{\mathrm{II}}=\mathrm{Ni}\right)$ substituted into the lattice. The variable $\mathrm{x}$ refers to the substitution level and $\delta$ is the relationship between $\mathrm{x}$ and the specific molecular formula. Two series of hexaaluminate catalysts were prepared at the Morgantown, WV site of NETL. The first series was synthesized for comparison of different elemental mirror cations while holding the Ni substitution level constant at $\mathrm{x}=0.4$. The second series was created with the same mirror cation of $\mathrm{Ba}$, but varies $\mathrm{x}$, the level of $\mathrm{Ni}$ substitution. 
The goal of this project is to obtain a fundamental understanding of the nature of active sites present in hexaaluminate catalysts. There are two primary objectives under consideration for this project. The first objective is to identify the phase of catalytically active $\mathrm{Ni}$ that has been substituted into the lattice of hexaaluminate catalysts. The second objective was to determine the location of $\mathrm{Ni}$ species in the hexaaluminate lattice during synthesis, reduction and reaction. The aforementioned investigations have demonstrated that the reducibility of Ni-substituted hexaaluminates depends strongly on the properties of $\mathrm{Ni}$, and is also affected by mirror cation type, ionic radius and valence level of the cation. Although the work performed at NETL and other institutions has resulted in a wealth of information, there are still many questions to be answered about the structure of Ni-substituted hexaaluminates and the behavior of active Ni. How does varying the Ni substitution level affect the hexaaluminate lattice of the Ba series of catalysts? What is the state of the $\mathrm{Ni}$ before and after reduction? Upon reduction, is the $\mathrm{Ni}$ exchanged within the hexaaluminate reduced to $\mathrm{Ni}^{0}$ metal or is it in the form of an oxygen-deficient mixed-metal oxide? If $\mathrm{Ni}$ ions are present, what is the average oxidation state?

This project is collaboration between NETL, West Virginia University (WVU) and Louisiana State University (LSU). Catalyst synthesis, reaction studies and initial testing have been performed at NETL. Characterization techniques will be conducted at WVU by means of the following methods: scanning electron microscopy (SEM), unitcell refinement (UCR) and Fourier-transform infrared (FT-IR) spectroscopy. Extended X-ray absorption fine-structure (EXAFS) and X-ray absorption near edge spectroscopy (XANES) of the samples will be simultaneously conducted by researchers at LSU.

The results from the characterization study will lead to more tailored testing and operating conditions to take advantage of the active sites of the hexaaluminate catalysts. After characterization, researchers at NETL will utilize the information with ongoing tests in SOFC-based APU to assess their capability under real-time reaction conditions. It is hoped that Ni-substituted hexaaluminates will be an inexpensive, long-lasting option for reforming catalysts in SOFC-based APU. This will result in the conservation of diesel fuel and a reduction in operating costs and the ensuing emission of pollutants from fuel combustion. 


\section{Chapter 2: Literature Review}

\subsection{Hexaaluminate Structure and Properties}

Hexaaluminates have been the subject of interest of a variety of research areas due to their ability to retain moderate surface areas up to $1400^{\circ} \mathrm{C}(7 ; 8)$, and to resist sintering, phase transformation and carbon deposition $(9 ; 10)$. It is believed that these properties originate from the hexaaluminate crystal structure $(9 ; 11)$. Hexaaluminates are hexagonal poly-aluminates having a lattice structure related to either magnetoplumbite or $\beta$-alumina and both forms are characterized by hexagonal symmetry of space group $\mathrm{P}_{3} / m m c$ (12). Hexaaluminates are of the general form $\mathrm{M}_{\mathrm{I}}\left(\mathrm{M}_{\mathrm{II}}\right)_{\mathrm{x}} \mathrm{Al}_{12-\mathrm{x}} \mathrm{O}_{19-\delta}$, where $\mathrm{M}_{\mathrm{I}}$ is the cation $\left(\mathrm{M}_{\mathrm{I}}=\mathrm{Ba}, \mathrm{Sr}, \mathrm{La}\right)$ and $\mathrm{M}_{\mathrm{II}}$ refers to the metal dopant $\left(\mathrm{M}_{\mathrm{II}}=\mathrm{Ni}\right)$ substituted for Al within the lattice (6). The variable $\mathrm{x}$ refers to the substitution level and $\delta$ is the relationship between $\mathrm{x}$ and the specific molecular formula. The ideal unit-cell structures of the magnetoplumbite and $\beta$-alumina hexaaluminate forms are illustrated as Figure 1 (7).

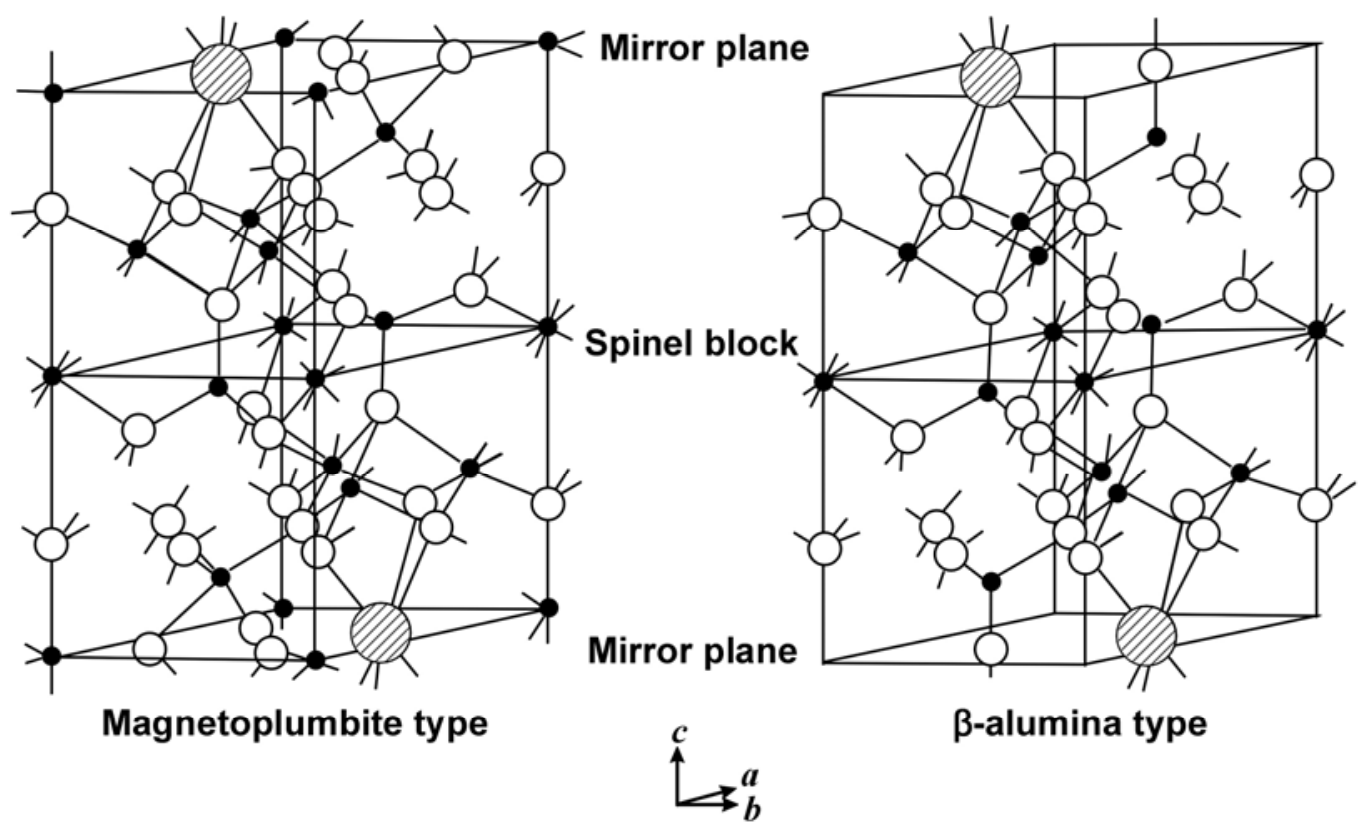

$\mathrm{Ba}, \mathrm{La}, \mathrm{Sr} \quad \bigcirc \mathrm{O} \quad \bullet \quad \mathrm{Al}$

Figure 1: Ideal unit-cell structures of hexaaluminates (7) 
The parent structures are composed of spinel structured blocks which are stacked together in such a manner that adjacent blocks are separated by cation containing mirror planes along the $c$ axis. Each spinel block consists of four oxygen layers with trivalent cations in both octahedral and tetrahedral sites (12). As illustrated by Figure 1, the $\beta$-alumina and magnetoplumbite structures are identical in the spinal block but the fundamental difference between the two configurations lies in the mirror plane regions. In the magnetoplumbite structure, the mirror plane contains an aluminum ion, three oxygen ions and a large cation. In the $\beta$-alumina structure there is only an oxygen ion and a large cation. These differences are largely due to the ionic radius and/or valence level of the mirror cation(s) used in the synthesis of the hexaaluminate.

The large cation of hexaaluminates is possible to be monovalent, divalent or trivalent. Hexaaluminates composed of large trivalent cations such as La have been found to be of a magnetoplumbite structure and are of the formula $\mathrm{M}_{\mathrm{I}} \mathrm{Al}_{11} \mathrm{O}_{18}$. Hexaaluminates containing a divalent cation ( $\mathrm{Ca}$, Sr etc.) are also of the magnetoplumbite structure with the general formula $\mathrm{M}_{\mathrm{I}} \mathrm{Al}_{12} \mathrm{O}_{19}$. Until the early seventies, $\mathrm{Ba}$ hexaaluminate was assigned to the magnetoplumbite structure with stoichiometry of $\mathrm{BaAl}_{12} \mathrm{O}_{19}$, like other hexaaluminates consisting of divalent cations (12). Many studies in the late seventies to mid eighties $(13 ; 14)$ revealed that the compound " $\mathrm{BaAl}_{12} \mathrm{O}_{19}$ " does not exist, except as a mixture of two distinct nonstoichiometric phases, first referred to as phase I and phase II by Kimura et al. (13). Further investigations by Iyi et al. $(14 ; 15)$ concluded that the barium hexaaluminate structure of phase I is of $\beta$-alumina type and has the structural formula $\mathrm{Ba}_{0.75} \mathrm{Al}_{11} \mathrm{O}_{17.25}$ and that the structure of phase II is of magnetoplumbite type and has the structural formula $\mathrm{Ba}_{2.34} \mathrm{Al}_{21.0} \mathrm{O}_{33.84}$.

\subsection{Previous Work on Hexaaluminates}

Several investigations have been performed on the substitution of various metals as metal dopants in the hexaaluminate lattice $(3 ; 6 ; 14 ; 16 ; 17)$. Although many metals (Mn, Pt, Co, Fe etc.) have had more successful results than Ni with regards to partial oxidation (POx) and combustion of $\mathrm{CH}_{4}(3 ; 6 ; 14)$, supported $\mathrm{Ni}$ catalysts are of interest industrially due to $\mathrm{Ni}$ being less expensive than the alternatives $(3 ; 10 ; 16)$. In order for Ni-substituted hexaaluminates to be active and selective, $\mathrm{Ni}$ sites within the cell lattice must be formed by the reduction of Ni-O bonds present in the lattice (18). The number of 
$\mathrm{Ni}$ sites that are reducible and their coordinative environment are properties that need to be evaluated.

Machida and coworkers (11) used a variety of experimental techniques in an investigation on a series of cation-substituted $\mathrm{Ba}$ hexaaluminates, $\mathrm{BaM}_{\mathrm{II}} \mathrm{Al}_{11} \mathrm{O}_{19-\delta}\left(\mathrm{M}_{\mathrm{II}}=\right.$ $\mathrm{Cr}, \mathrm{Mn}, \mathrm{Fe}, \mathrm{Co}$ and $\mathrm{Ni}$ ). The crystal structure of a hexaaluminate is retained for $\mathrm{BaM}_{\mathrm{II}} \mathrm{Al}_{11} \mathrm{O}_{19-\delta}$ in which one $\mathrm{Al}$ site per every double spinel block is replaced by an $\mathrm{M}_{\mathrm{II}}$ ion. In situ thermogravimetry (TG) measurements of cation-substituted $\mathrm{Ba}$ hexaaluminates concluded that the average oxidation state of nickel was determined to be divalent. Transmission electron microscopy (TEM) observation indicated that crystal growth along the $c$ axis is strongly suppressed compared to that along the directions normal to the $c$ axis $(a, b)$. Machida et al. (11) have also reported the same crystal morphology in previous investigations on $\mathrm{BaAl}_{12} \mathrm{O}_{19}$ (19) and found the crystal growth patterns are a common feature among hexaaluminate-related compounds. The investigators conclude that the crystal growth suppression along the $c$ axis is the reason why hexaaluminates are able to retain a large surface area after calcination at $1300^{\circ} \mathrm{C}$ and the reduction/oxidation behavior of the transition elements in the crystal lattice influence the catalytic activity of the metal doped substituted hexaaluminate (11).

$\mathrm{Xu}$ and coworkers (10) designed a series of Ni-substituted La hexaaluminate catalysts for $\mathrm{CO}_{2}$ reforming of methane to synthesis gas and used the characterization methods of X-ray diffraction (XRD), X-ray photoelectron spectroscopy (XPS) and temperature-programmed reduction (TPR). X-ray diffraction and TPR results indicated that the basic La hexaaluminate structure showed very little change when exposed to high temperatures and that TPR plots showed the appearance of a $\mathrm{Ni}^{0}$ phase after reduction that indicated a large fraction of metallic $\mathrm{Ni}^{0}$ had separated from the hexaaluminate phase to form an individual metallic phase. The reduction profiles showed higher intensities of $\mathrm{Ni}^{0}$ peaks with increased $\mathrm{Ni}$ substitution. The investigators suggested that a large fraction of metallic $\mathrm{Ni}^{0}$ is separated from $\mathrm{Ni}^{2+}$ ions in the hexaaluminate lattice to form an individual metallic phase at $1100^{\circ} \mathrm{C}$ and that the metallic $\mathrm{Ni}^{0}$ is the active component for reaction.

Another notable observation by $\mathrm{Xu}$ et al. (10) is that Ni-substitution in the range of $0<\mathrm{x} \leq 1$ results in the formation of catalysts with hexaaluminate structure of $\mathrm{LaNi}_{\mathrm{x}} \mathrm{Al}_{12-\mathrm{x}} \mathrm{O}_{19-\delta} . \mathrm{X}$-ray photoelectron spectroscopy results indicated that less than $1 \%$ of 
the Ni lies on the surface of the hexaaluminate lattice and the majority remains in the catalyst bulk. Considering the limitations on the amount of Ni that may be substituted in the lattice and remain hexaaluminate form, it is not expected that any Ni-substituted hexaaluminate catalysts will have a large availability of $\mathrm{Ni}$ sites on the surface for reaction.

$\mathrm{Xu}$ and others (9) also studied the $\mathrm{CO}_{2}$ reforming of methane to synthesis gas over a series of $\mathrm{Ca}, \mathrm{Sr}, \mathrm{Ba}$ and $\mathrm{La}$ Ni-substituted catalysts and utilized the same characterization techniques as previously mentioned: XRD, XPS and TPR. Results of this investigation confirm that in each mirror-cation-type hexaaluminate, the Ni ions in the lattice are stable, have only oxidation state $\mathrm{Ni}^{2+}$ and only a part of these ions are reduced to $\mathrm{Ni}^{0}$ at $1100^{\circ} \mathrm{C}$. When alkaline earth metals are doped, the reduction peak temperature decreases with an increase in the ionic radius of the mirror cation. Overall, the Ni-substituted La hexaaluminate gives the lowest reduction temperature. It was observed that the catalytic activity is directly proportional to the ionic radius of the mirror cation. The activity sequence of the reduced hexaaluminates followed the order of $\mathrm{LaNiAl}_{11} \mathrm{O}_{19-\delta}>\mathrm{BaNiAl}_{11} \mathrm{O}_{19-\delta}>\mathrm{SrNiAl}_{11} \mathrm{O}_{19-\delta}>\mathrm{CaNiAl}_{11} \mathrm{O}_{19-\delta}$.

Chu and company $(16 ; 20)$ studied the $\mathrm{POx}$ of $\mathrm{CH}_{4}$ to syngas over a series of $\mathrm{Ni}$ modified Ba hexaaluminate catalysts. Characterization techniques of XRD, FT-IR, XPS and TPR were conducted on catalysts with the form of $\mathrm{BaNi}_{\mathrm{x}} \mathrm{Al}_{12-\mathrm{x}} \mathrm{O}_{19-\delta}$, where $\mathrm{x}=0.3$, 0.6, 0.9 and 1.0. Neither pure $\mathrm{NiO}$ nor $\mathrm{BaAl}_{12} \mathrm{O}_{19}$ showed satisfactory activity for the methane oxidation reaction, but $\mathrm{BaNi}_{\mathrm{x}} \mathrm{Al}_{12-\mathrm{x}} \mathrm{O}_{19-\delta}$ catalysts showed high levels of activity for the same reaction conditions. The results of XPS indicated that after $100 \mathrm{~h}$ of testing, the $\mathrm{Ni} / \mathrm{Al}$ ratio was nearly unchanged from the level in the fresh catalyst and suffered low levels of carbon deposition (16). It was found that catalytic activity and CO selectivity increased with increasing levels of nickel substitution, but only when the weight of $\mathrm{Ni}$ is lower than $2 \%(20)$. There was little to no change when more than $2 \%$ was present. This behavior was attributed to decomposition of the support structure by too much of metal dopant dispersed in the lattice or due to crystallization of the active species.

In 2007 at the NETL, Gardner et al. (18) conducted reforming studies on Nisubstituted hexaaluminate catalysts, $\mathrm{M}_{\mathrm{I}} \mathrm{Ni}_{0.4} \mathrm{Al}_{11.6} \mathrm{O}_{19-\delta}\left(\mathrm{M}_{\mathrm{I}}=\mathrm{La}, \mathrm{Sr}\right.$ and $\left.\mathrm{Ba}\right)$, to reform liquid hydrocarbon fuels into $\mathrm{H}_{2}$-rich synthesis gas for fuel cell applications. Experiments with the POx of $n$-tetradecane, with and without dibenzothiophene, were 
conducted to test the stability and sulfur poisoning resistance of the Ni-substituted hexaaluminates and the results were correlated to the Ni surface concentration and the $\mathrm{Ni}$ dispersion induced by the mirror cation. The divalent catalysts, $\mathrm{SrNi}_{0.4} \mathrm{Al}_{11.6} \mathrm{O}_{19-\delta}$ and $\mathrm{BaNi}_{0.4} \mathrm{Al}_{11.6} \mathrm{O}_{19-\delta}$, showed stable performance with reaction of $n$-tetradecane, whereas $\mathrm{LaNi}_{0.4} \mathrm{Al}_{11.6} \mathrm{O}_{19-\delta}$ exhibited declining activity and indicated $\mathrm{C}$ deposition on the surface which blocked active Ni sites. The results suggested that the different mirror cations influenced the coordination of $\mathrm{Ni}$ sites within the lattice and adsorption of hydrocarbons to the surface of the catalysts.

The catalysts were examined for the formation of metallic $\mathrm{Ni}^{0}$ after undergoing $n$ tetradecane POx. The formation of metallic $\mathrm{Ni}^{0}$ peaks was observed in both $\mathrm{LaNi}_{0.4} \mathrm{Al}_{11.6} \mathrm{O}_{19-\delta}$ and $\mathrm{SrNi}_{0.4} \mathrm{Al}_{11.6} \mathrm{O}_{19-\delta}$ indicating that some of the $\mathrm{Ni}^{+2}$ initially present within the hexaaluminate lattice was reduced and separated to form an individual metallic phase. There was no discernable evidence of formation of $\mathrm{Ni}$ peaks in $\mathrm{BaNi}_{0.4} \mathrm{Al}_{11.6} \mathrm{O}_{19-\delta}$; however this was attributed to peak overlap between the Ba hexaaluminate phase and the metallic $\mathrm{Ni}^{0}$ phase. X-ray photoelectron spectroscopy and $\mathrm{H}_{2}$ pulse chemisorptions techniques were utilized to determine the concentration of $\mathrm{Ni}$ at the surface of the catalyst and resulted in the order of: $\mathrm{LaNi}_{0.4} \mathrm{Al}_{11.6} \mathrm{O}_{19-\delta}>\mathrm{SrNi}_{0.4} \mathrm{Al}_{11.6} \mathrm{O}_{19-\delta}>\mathrm{BaNi}_{0.4} \mathrm{Al}_{11.6} \mathrm{O}_{19-\delta}$.

Gardner et al. (18) also examined the effect of the mirror cation on the formation of reduced $\mathrm{Ni}$ sites. The catalysts were each subjected to a reducing environment and $\mathrm{Ni}$ dispersions were tabulated. Table 1 (18) illustrates the values of the surface area, dispersion and bulk and surface $\mathrm{Ni}$ concentrations of the three mirror cation hexaaluminate catalysts obtained by the study.

Table 1: Surface Area, Dispersion and Bulk Surface Ni Concentration of Nisubstituted Hexaaluminate Catalysts (18)

\begin{tabular}{|c|c|c|c|c|c|}
\hline $\begin{array}{c}\text { Mirror } \\
\text { Cation }\end{array}$ & Catalyst & $\begin{array}{c}\text { Surface } \\
\text { Area } \\
\left(\mathrm{m}^{2} / \mathrm{g}\right)\end{array}$ & $\begin{array}{c}\text { Dispersion } \\
(\mathrm{H} / \mathrm{Ni})\end{array}$ & $\begin{array}{c}\text { Bulk Ni } \\
\text { Concentration } \\
\text { (wt. \%) }\end{array}$ & $\begin{array}{c}\text { Surface Ni } \\
\text { Concentration } \\
\text { (wt. \%) }\end{array}$ \\
\hline $\mathrm{La}$ & $\mathrm{LaNi}_{0.4} \mathrm{Al}_{11.6} \mathrm{O}_{19-\delta}$ & 22.6 & 0.025 & 2.11 & 5.3 \\
\hline $\mathrm{Ba}$ & $\mathrm{BaNi}_{0.4} \mathrm{Al}_{11.6} \mathrm{O}_{19-\delta}$ & 14.3 & 0.0095 & 2.33 & $<0.1$ \\
\hline $\mathrm{Sr}$ & $\mathrm{SrNi}_{0.4} \mathrm{Al}_{11.6} \mathrm{O}_{19-\delta}$ & 16.2 & 0.019 & 2.30 & 0.7 \\
\hline
\end{tabular}


The Ni dispersions were determined to follow the same order as the Ni concentration at the surface: $\mathrm{LaNi}_{0.4} \mathrm{Al}_{11.6} \mathrm{O}_{19-\delta}>\mathrm{SrNi}_{0.4} \mathrm{Al}_{11.6} \mathrm{O}_{19-\delta}>\mathrm{BaNi}_{0.4} \mathrm{Al}_{11.6} \mathrm{O}_{19-\delta}$. Due to the $\mathrm{Ni}$ dispersions for all three catalyst types being less than $3 \%$, the results indicate that most of the Ni remained as Ni-O within the lattice, leading the investigators to observe that only a fraction of the Ni sites are reduced and responsible for catalytic activity (18). However, the low dispersions may also indicate that the metal particles are large and only a portion lies on the catalyst surface.

Gardner (6) further investigated various levels of Co, Fe and Ni-substituted La hexaaluminate catalysts, in addition to the Ni-substituted $\mathrm{Sr}$ and $\mathrm{Ba}$ catalyst series previously mentioned. Hydrogen consumption measurements during TPR of the catalysts suggest that the mirror cation has a large effect on the reduction temperature, with reduction peak temperatures of $982^{\circ} \mathrm{C}$ for $\mathrm{LaNi}_{0.4} \mathrm{Al}_{11.6} \mathrm{O}_{19-\delta}$ and $938^{\circ} \mathrm{C}$ for $\mathrm{SrNi}_{0.4} \mathrm{Al}_{11.6} \mathrm{O}_{19-\delta}$. $\mathrm{BaNi}_{0.4} \mathrm{Al}_{11.6} \mathrm{O}_{19-\delta}$ had a low-temperature peak location at $611^{\circ} \mathrm{C}$ and a high-level peak at $1064^{\circ} \mathrm{C}$. TPR data show that reduction occurs at temperatures above $800^{\circ} \mathrm{C}$, suggesting that $\mathrm{Ni}$ has been incorporated into the hexaaluminate structure since $\mathrm{Ni}-\mathrm{O}$ is reduced to $\mathrm{Ni}^{0}$ metal around $300^{\circ} \mathrm{C}$. Hydrogen consumption peak data correlated with dopant substitution level led to the observation that increasing the degree of $\mathrm{Ni}$ modification resulted in an increase of accessible reduced $\mathrm{Ni}-\mathrm{O}$ sites. It was observed that relative to $\mathrm{La}$ and $\mathrm{Sr}$, the $\mathrm{Ba}$ mirror cation produced a stabilizing effect on the Ni-O bond in the hexaaluminate lattice. This behavior led to the suggestion that reduced Ni sites were located in a region near the mirror cation and reduction was influenced by the type of mirror cation present in the lattice.

Hexaaluminate catalysts for this project were prepared by Todd Gardner and Mark Smith at the DOE's NETL facility in Morgantown, WV. The hexaaluminates are of the form $\mathrm{M}_{\mathrm{I}}\left(\mathrm{M}_{\mathrm{II}}\right)_{\mathrm{x}} \mathrm{Al}_{12-\mathrm{x}} \mathrm{O}_{19-\delta}$, where $\mathrm{M}_{\mathrm{I}}$ is the cation $\left(\mathrm{M}_{\mathrm{I}}=\mathrm{Ba}, \mathrm{Sr}, \mathrm{La}\right), \mathrm{M}_{\mathrm{II}}$ refers to the metal dopant $\left(\mathrm{M}_{\mathrm{II}}=\mathrm{Ni}\right)$ substituted into the lattice, $\mathrm{x}$ is the substitution level and $\delta$ is the relationship between $\mathrm{x}$ and the specific molecular formula. The catalysts include a series of $\mathrm{Ba}$ hexaaluminates where the Ni substitution level was varied from $\mathrm{x}=0.2,0.4,0.6$, 0.8 and 1.0. An additional $\mathrm{Ba}$ hexaaluminate catalyst sample was included for comparison with $\mathrm{x}=0.0 \mathrm{Ni}$ substitution. Another series of samples kept the Ni level constant at $\mathrm{x}=0.4$ but varied the mirror cation, using $\mathrm{Ba}, \mathrm{Sr}$ or La. 
The investigators chose to employ liquid-phase coprecipitation to synthesize the catalysts (6). The first step of preparing the catalysts was to weigh out the calculated amount of nitrate precursor salts to create the desired hexaaluminate. The salts were dissolved in $300 \mathrm{~mL}$ of de-ionized water stirred continuously at $60^{\circ} \mathrm{C}$. The requisite amount of ammonium carbonate needed to neutralize the nitrates was measured and dissolved in a separate container of $300 \mathrm{~mL}$ of de-ionized water stirred continuously at $30^{\circ} \mathrm{C}$. For example, synthesizing $20 \mathrm{~g}$ of $\mathrm{BaNi}_{0.4} \mathrm{Al}_{11.6} \mathrm{O}_{18.8}$ requires $55.39 \mathrm{~g}$ of ammonium carbonate, $112.36 \mathrm{~g}$ of $\mathrm{Al}$ nitrate, $6.75 \mathrm{~g}$ of Ba nitrate and $3.00 \mathrm{~g}$ of Ni nitrate. The $\mathrm{pH}$ of the solutions ranged from 8.5 to 9.0 for the ammonium carbonate and 1.0 to 2.0 for the nitrates. The nitrate solution was added drop-wise through a separatory funnel to the ammonium carbonate solution until a combined $\mathrm{pH}$ of 7.5 was achieved.

The resultant gel was aged at $60^{\circ} \mathrm{C}$ for six hours under vigorous mixing conditions. After aging, the gel was separated by vacuum filtration and rinsed three times with de-ionized water to remove excess nitrates. The filter cake was dried overnight at $110^{\circ} \mathrm{C}$, crushed and placed in an oven. The samples were decomposed at $425^{\circ} \mathrm{C}$ in air for $1 \mathrm{~h}$ and then calcined at $1250-1400^{\circ} \mathrm{C}$ for $2-6 \mathrm{~h}$. Earlier samples were calcined at $1250^{\circ} \mathrm{C}$ for $2 \mathrm{~h}$. Samples synthesized later were calcined for one hour at each temperature with set points of $900^{\circ} \mathrm{C}, 1000^{\circ} \mathrm{C}, 1100^{\circ} \mathrm{C}, 1200^{\circ} \mathrm{C}, 1300^{\circ} \mathrm{C}$ and $1400^{\circ} \mathrm{C}$ in a ramp-and-soak manner. Table 2 illustrates the synthesis conditions of the catalysts to be investigated. 
Table 2: Ni-Substituted Hexaaluminates Synthesis Conditions

\begin{tabular}{|c|c|c|c|}
\hline $\begin{array}{c}\text { Sample Name } \\
{[\text { ID\#\#] }}\end{array}$ & $\begin{array}{c}\text { Mirror } \\
\text { Cation }\end{array}$ & $\begin{array}{c}\text { Ni substitution } \\
\text { Level }\end{array}$ & $\begin{array}{c}\text { Calcination } \\
\text { Conditions }\end{array}$ \\
\hline $\mathrm{LaNi}_{0.4} \mathrm{Al}_{11.6} \mathrm{O}_{19}$ & Lanthanum & 0.4 & $1250^{\circ} \mathrm{C}$ \\
{$[35]$} & & & $\mathrm{h}$ \\
\hline $\mathrm{SrNi}_{0.4} \mathrm{Al}_{11.6} \mathrm{O}_{19}$ & Strontium & 0.4 & $1250^{\circ} \mathrm{C}$ \\
{$[52]$} & & & $2 \mathrm{~h}$ \\
\hline $\mathrm{BaNi}_{0.4} \mathrm{Al}_{11.6} \mathrm{O}_{18.8}$ & Barium & 0.4 & $1300^{\circ} \mathrm{C}$ \\
{$[75]$} & & & $4 \mathrm{~h}$ \\
\hline $\mathrm{BaAl}_{12} \mathrm{O}_{19}$ & Barium & 0.0 & $1300^{\circ} \mathrm{C}$ \\
{$[38 \mathrm{C}]$} & & 0.2 & $6 \mathrm{~h}$ \\
\hline $\mathrm{BaNi}_{0.2} \mathrm{Al}_{11.8} \mathrm{O}_{18.9}$ & Barium & & $900-1400^{\circ} \mathrm{C}$ \\
{$[115 \mathrm{~B}]$} & & 0.4 & $6 \mathrm{~h}^{*}$ \\
\hline $\mathrm{BaNi}_{0.4} \mathrm{Al}_{11.6} \mathrm{O}_{18.8}$ & Barium & & $900-1400^{\circ} \mathrm{C}$ \\
{$[116 \mathrm{~B}]$} & & 0.6 & $6 \mathrm{~h}^{*}$ \\
\hline $\mathrm{BaNi}_{0.6} \mathrm{Al}_{11.4} \mathrm{O}_{18.7}$ & Barium & & $600-1400^{\circ} \mathrm{C}$ \\
{$[117 \mathrm{~B}]$} & & 0.8 & $6 \mathrm{~h}^{*}$ \\
\hline $\mathrm{BaNi}_{0.8} \mathrm{Al}_{11.2} \mathrm{O}_{18.6}$ & Barium & & $600-1400^{\circ} \mathrm{C}$ \\
{$[118 \mathrm{~B}]$} & & 1.0 & $9 \mathrm{~h}^{*}$ \\
\hline $\mathrm{BaNiAl}_{11} \mathrm{O}_{18.5}$ & Barium & & $6 \mathrm{~h}^{*}$ \\
\hline$[119 \mathrm{~B}]$ & & & $1400^{\circ} \mathrm{C}$ \\
\hline
\end{tabular}

$* 6$ hours total calcination time, 1 hour each at $900,1000,1100,1200,1300,1400^{\circ} \mathrm{C}$

In addition to the experiments performed at NETL on various hexaaluminates, some initial tests were conducted by Gardner et al. $(6 ; 18)$ on Ni-substituted Ba hexaaluminates (21). Figure 2 (21) illustrates the $\mathrm{H}_{2}$ consumption measurements during temperature programmed reduction of the Ni-substituted Ba series. 


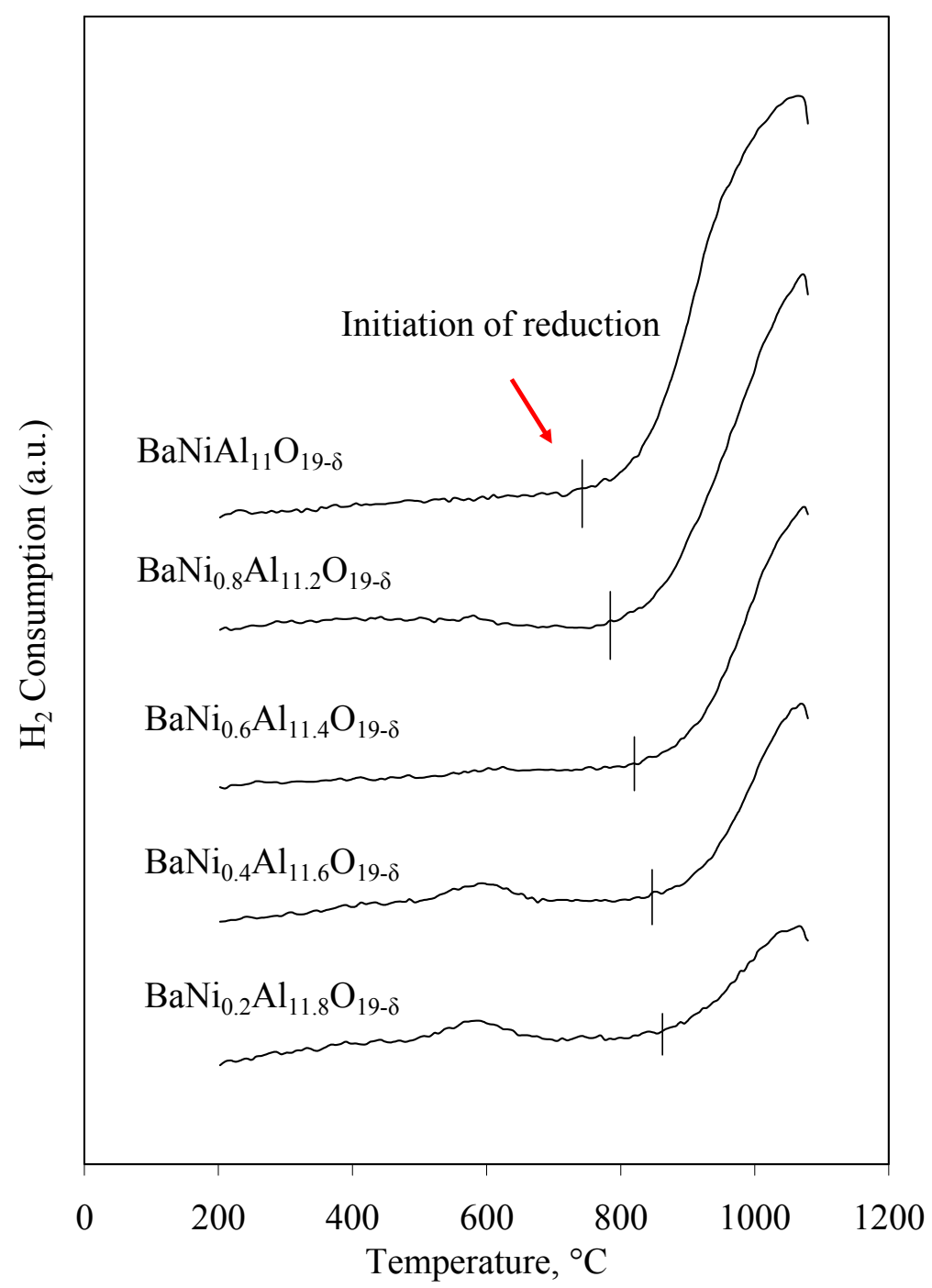

Figure 2: $\mathrm{H}_{2}$ consumption curves illustrating the reduction temperatures of Ni-substituted Ba hexaaluminates (21)

As can be seen in Figure 2, the level of Ni substitution has a direct effect on the reduction temperatures of the hexaaluminate catalysts. The higher the Ni substitution, the lower the temperature for initiation of reduction and the higher the intensity of the $\mathrm{H}_{2}$ consumption peaks. The two samples with the lowest $\mathrm{Ni}$ substitution, $\mathrm{BaNi}_{0.2} \mathrm{Al}_{11.8} \mathrm{O}_{19-\delta}$ [115B] and $\mathrm{BaNi}_{0.4} \mathrm{Al}_{11.6} \mathrm{O}_{19-\delta}[116 \mathrm{~B}]$, have an additional reduction peak around $600^{\circ} \mathrm{C}$. Gardner (6) previously studied the $\mathrm{H}_{2}$ consumption peaks of the $\mathrm{Ni}_{0.4}$-substituted $\mathrm{La}, \mathrm{Sr}$ and $\mathrm{Ba}$ series of samples which indicated the mirror cation also has a large effect on reduction conditions. 
The temperature-programmed oxidation (TPO) reaction of $\mathrm{CH}_{4}$ over inert quartz chips versus $\mathrm{BaNi}_{0.8} \mathrm{Al}_{11.2} \mathrm{O}_{19-\delta}$ is illustrated in Figure 3 (21) and Figure 4 (21).

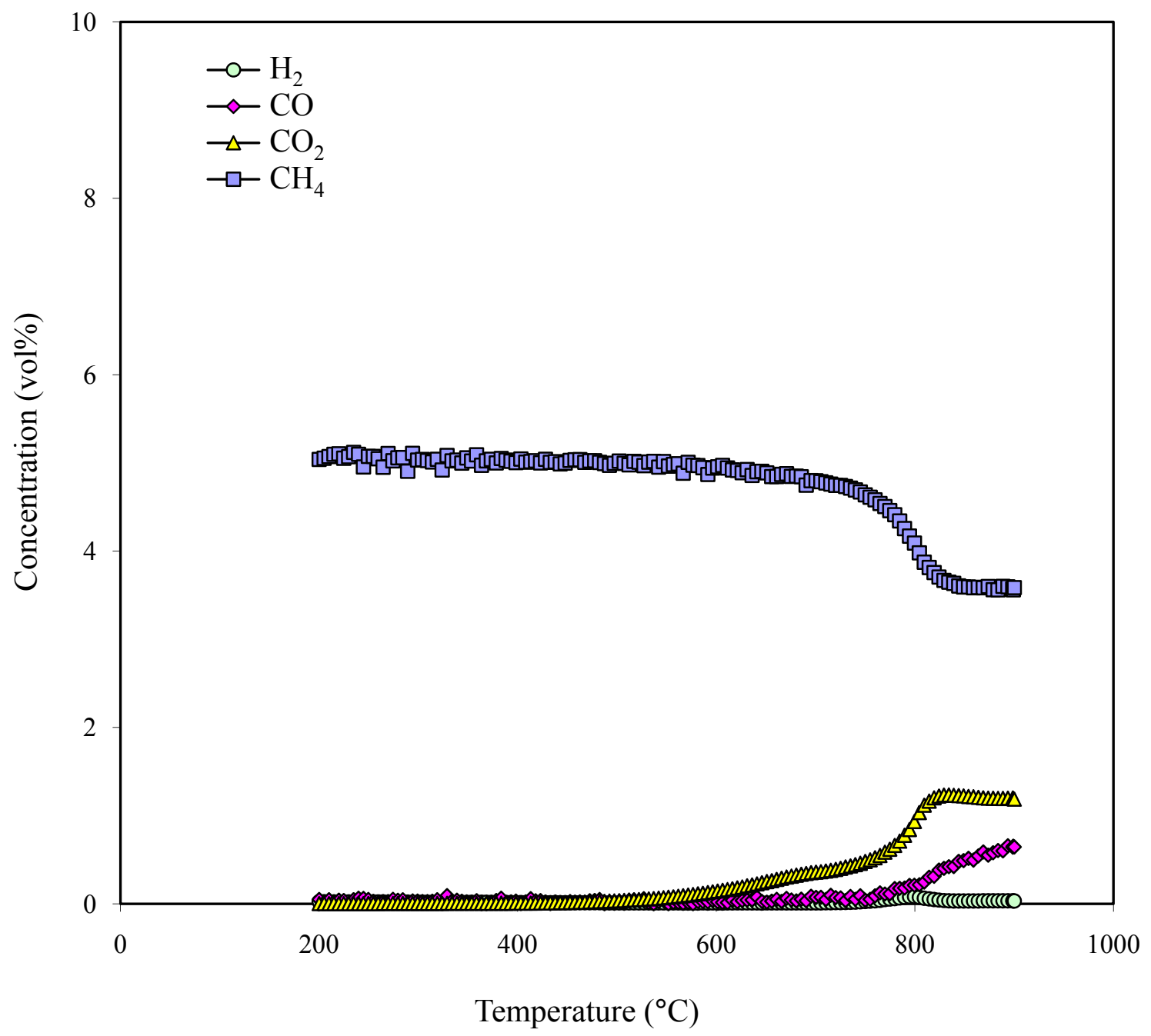

Figure 3: Temperature programmed oxidation of $\mathrm{CH}_{4}$ over quartz (21) 


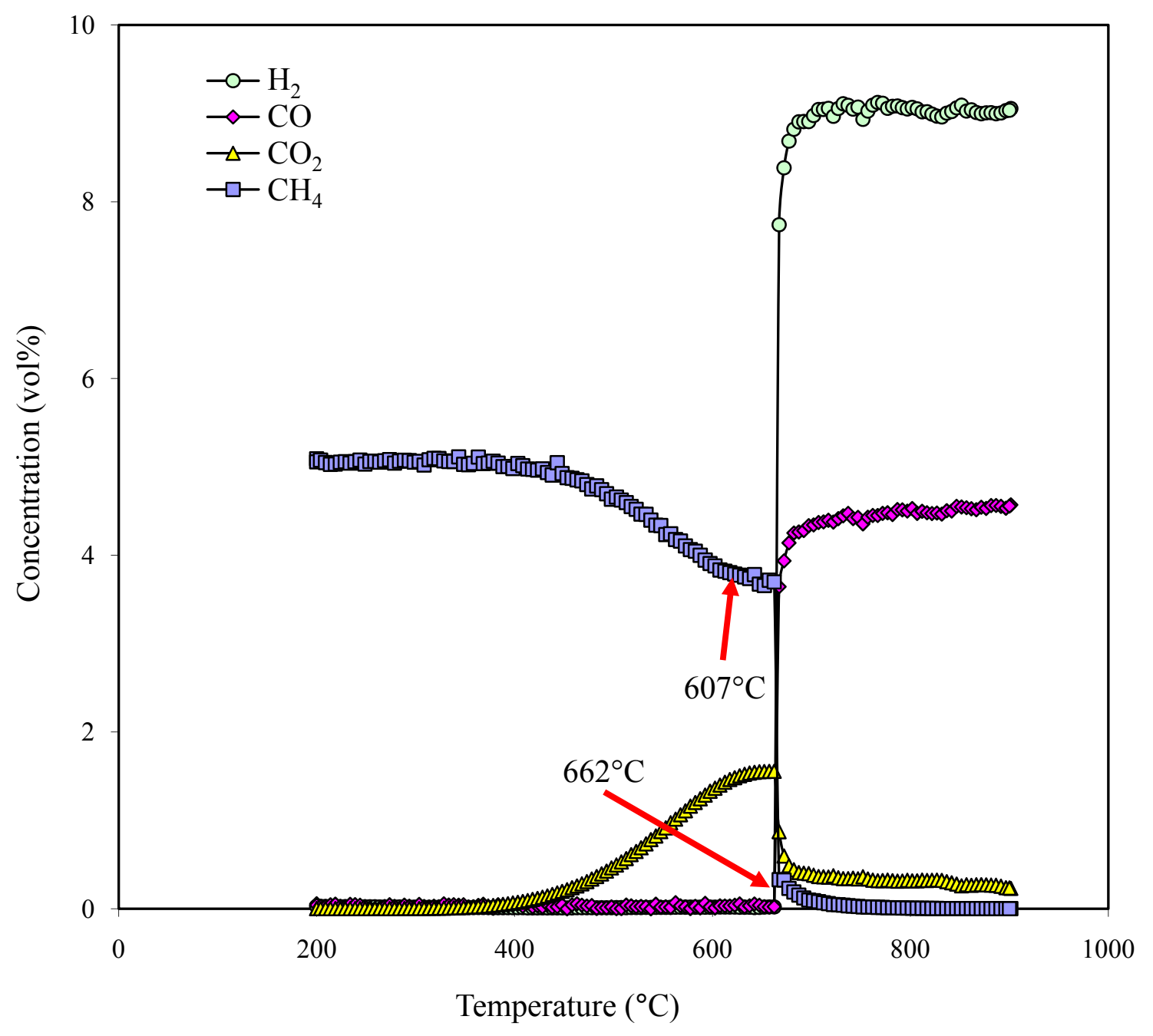

Figure 4: Temperature programmed oxidation of $\mathrm{CH}_{4}$ over $\mathrm{BaNi}_{0.8} \mathrm{Al}_{11.2} \mathrm{O}_{19.6}$ (21)

For both cases of the $\mathrm{BaNi}_{0.8} \mathrm{Al}_{11.2} \mathrm{O}_{19-\delta}[118 \mathrm{~B}]$ catalyst and quartz, no reaction was observed over the temperature range of $200^{\circ} \mathrm{C}$ to $400^{\circ} \mathrm{C}$. Between $400^{\circ} \mathrm{C}$ to around $660^{\circ} \mathrm{C}$, the $\mathrm{BaNi}_{0.8} \mathrm{Al}_{11.2} \mathrm{O}_{19-\delta}[118 \mathrm{~B}]$ catalyst allows for the combustion of $\mathrm{CH}_{4}$ and resulting formation of $\mathrm{CO}_{2}$ whereas the quartz chips indicated no activity. Around $660^{\circ} \mathrm{C}$, catalyst light-off occurred, which is the minimum temperature necessary to initiate the catalytic reaction. $\mathrm{All}_{\mathrm{BaNi}} \mathrm{Al}_{12-\mathrm{x}} \mathrm{O}_{19-\delta}$ catalysts within the series produced similar catalytic behaviors. After reaction to $900^{\circ} \mathrm{C}$, it was observed that the upper portion of the bed remained blue and free of $\mathrm{C}$ deposition. The lower portion achieved a gray appearance, suggesting that either some carbon formation occurred in the 
downstream portion of the bed (21) or that $\mathrm{Ni}^{+2}$ ions, with characteristic blue color, have been reduced to $\mathrm{Ni}^{0}$ metal and turned from blue to gray.

In a similar characterization study to this project, Bukhtiyarova et al. (22) performed XRD and FTIR spectroscopy of adsorbed probe molecules ( $\mathrm{CO}$ and $\left.\mathrm{CDCl}_{3}\right)$ on $\mathrm{SrAl}_{12} \mathrm{O}_{19}, \mathrm{BaAl}_{12} \mathrm{O}_{19}$ and $\mathrm{LaAl}_{11} \mathrm{O}_{18}$. The Bukhtiyarova samples were created via the coprecipitation method under similar conditions to the samples synthesized at NETL by Gardner $(6 ; 22)$. The XRD profiles were recorded with $\mathrm{Cu} \mathrm{K}_{\alpha}(\lambda=1.5418 \AA$ ) radiation and in both continuous and step-by-step scanning modes at $0.05-0.1^{\circ}$ in $2 \theta$ and dwell time of 20-30 sec depending on the crystallinity of the sample (22). X-ray diffraction confirmed the formation of single-phase hexaaluminates in the $\mathrm{SrAl}_{12} \mathrm{O}_{19}$ and $\mathrm{BaAl}_{12} \mathrm{O}_{19}$ samples; however the $\mathrm{LaAl}_{11} \mathrm{O}_{18}$ sample contained an additional $\mathrm{LaAlO}_{3}$ phase. It was also observed that the cell parameters changed with increasing temperature during calcination: $a, b$ directions increased for all three of the samples, while the $c$ direction decreased for all the samples except for $\mathrm{BaAl}_{12} \mathrm{O}_{19}$.

\subsection{Characterization Techniques}

Several characterization techniques will be applied to investigate the two series of catalysts. Characterization techniques will be conducted at WVU by means of the following methods: scanning electron microscopy (SEM), unit-cell refinement (UCR), simultaneous temperature-programmed reduction and X-ray diffraction (TPR-XRD) and Fourier-transform infrared (FT-IR) spectroscopy. Scanning electron microscopy will be used to determine differences in catalyst surface morphology. Unit-cell refinement will confirm that $\mathrm{Ni}$ is incorporated into hexaaluminate lattice. Temperature-programmed reduction and X-ray diffraction will allow the monitoring of changes in structure and the formation of metal-oxygen species during reduction conditions. Temperature programmed reduction under $\mathrm{H}_{2}$ followed by $\mathrm{CO}$ pulse chemisorption will also be performed on the samples to determine reduction temperatures and level of $\mathrm{Ni}^{0}$ on the catalyst surface to optimize FT-IR measurement conditions. Fourier-transform infrared spectroscopy will detect surface species adsorbed on reduced catalyst and distinguish between $\mathrm{Ni}^{+2}$ ions and $\mathrm{Ni}^{0}$ metal. The results obtained from each of the techniques will be analyzed and combined in order to gather a clearer understanding of the activity of $\mathrm{Ni}$ 
on the hexaaluminate catalysts surfaces and what effect varying the cations and $\mathrm{Ni}$ substitution level have on the hexaaluminate structure.

The first characterization technique to be performed on the hexaaluminate catalysts will be SEM. Scanning electron microscopy images of magnification levels up to $10 \mathrm{k}$ will be taken on equipment available at WVU. These images illustrate any differences in surface morphology between samples of varying composition as well as fresh versus spent catalysts.

Temperature-programmed reduction is a technique used to indicate the relative strength of metal-oxygen bonds present in the lattice. For Ni substituted into the hexaaluminate lattice to become catalytically active, the $\mathrm{Ni}-\mathrm{O}$ bond within the lattice must be reduced (18). The reduced Ni sites form either metallic $\mathrm{Ni}^{0}$ or remain as a defect site within the lattice as a $\mathrm{Ni}$ ion. If metallic $\mathrm{Ni}^{0}$ sites form, either the active sites exist as nano-dispersed $\mathrm{Ni}$ sites embedded at the surface, or metallic $\mathrm{Ni}^{0}$ clusters may form if the reduced sites are in a high concentration. Temperature-programmed reduction shows the energy required to reduce $\mathrm{Ni}$ within the hexaaluminate lattice as well as the temperature range in which reduction occurs.

Unit-cell refinement (UCR) (23) is a technique commonly utilized in mineralogical and petrological research to determine lattice parameters of materials from XRD diffraction patterns of actual observed data. The lattice parameters are calculated via non-linear least-squares refinement of the whole diffraction pattern and also incorporate regression diagnostics to detect and dismiss outliers that may skew results. In this study, the XRD software Jade was utilized to calculate the lattice parameters of the samples and the results are given in the form of $a, b$ and $c$ parameters, the overall lattice cell volume and the respective standard error of each measurement.

In situ time-resolved studies of the formation of catalysts are important in order to understand the synthesis mechanisms. Using time-resolved XRD, it is possible to follow structural changes during TPR and temperature-programmed oxidation (TPO). It has been shown that $\mathrm{O}_{2}$ diffusion is preferred to occur via the $\mathrm{O}^{-2}$ ions within the monatomic layer of the mirror plane rather than those present in the spinel block (24). Under TPR it is anticipated that $\mathrm{O}^{-2}$ ions within the mirror plane of $\mathrm{Ni}$-substituted hexaaluminates will reduce and expose active $\mathrm{Ni}^{0}$ sites. In situ observation also enables detection of intermediate phases, helps in establishing optimal synthesis conditions and makes it 
possible to investigate the kinetics of phase transitions and to determine the changes of crystallite size as a function of time and reaction conditions (25). In situ time-resolved XRD will be executed by simultaneously performing TPR and TPO while scanning the samples via XRD under high intensity synchrotron radiation. Synchrotron measurements provide high positional accuracy and excellent signal-to-noise ratio.

As previously mentioned in Section $2.2, \mathrm{Xu}$ and coworkers $(9 ; 10)$ performed TPR with catalyst embedded in a fixed-bed quartz tube, although XRD measurements were not simultaneously taken during the procedure. Before reaction, the samples were treated at $300^{\circ} \mathrm{C}$ under $\mathrm{Ar}$ for $30 \mathrm{~min}$ and cooled to room temperature. The samples were then heated to $1200^{\circ} \mathrm{C}$ at $20^{\circ} \mathrm{C} / \mathrm{min}$ under $10 \% \mathrm{H}_{2} / \mathrm{Ar}$ gas mixture at a flow rate of 30 $\mathrm{ml} / \mathrm{min}$. Chu et al. (16) chose similar conditions for TPR studies but used $5 \% \mathrm{H}_{2} / \mathrm{Ar}$ and the sample was heated to $1250^{\circ} \mathrm{C}$.

Unit-cell refinement and in situ time-resolved XRD characterization will be conducted at the X7B beam line of the National Synchrotron Light Source (NSLS) facility at Brookhaven National Laboratory (BNL) in Upton, NY. Investigations conducted at the NSLS facility at BNL as well as other institutions have resulted in the practicality of conducting subminute, time-resolved XRD experiments under a wide variety of temperature $\left(-190^{\circ} \mathrm{C}\right.$ to $\left.900^{\circ} \mathrm{C}\right)$ and pressure $(<45 \mathrm{~atm})$ conditions $(25 ; 26)$. Poul Norby, a BNL chemist, and Jonathan Hanson, beam line scientist of the X7B beam line, have both helped to develop in situ diffraction techniques that are available for researchers who visit BNL.

The NSLS X7B beamline offers a vertically and horizontally focused beam, making it possible to obtain high intensity in a small spot (27). For time-resolved XRD experiments performed at $\mathrm{X} 7 \mathrm{~B}$, a sample in a sapphire capillary tube mounted horizontally in front of an imaging plate detector. Under operation, the image plate collects a continuous series of powder diffraction profiles as a function of time. The time resolution depends on the exposure time needed to obtain a satisfactory diffraction pattern and the time needed to transmit this data to a computer. Typically exposure times are 1 to 3.5 minutes and transfer times are 1.5 minutes so that data can be collected at 2.5 to 5 minute intervals. The imaging data are obtained in the form of Debye-Scherrer rings that upon integrating lead to structural information about the sample (27). Both the position and intensity of the rings are an indication of the structure and crystallinity of the 
sample. The geometry of the experimental set-up was acquired from Norby (27) and is shown as Figure 4.

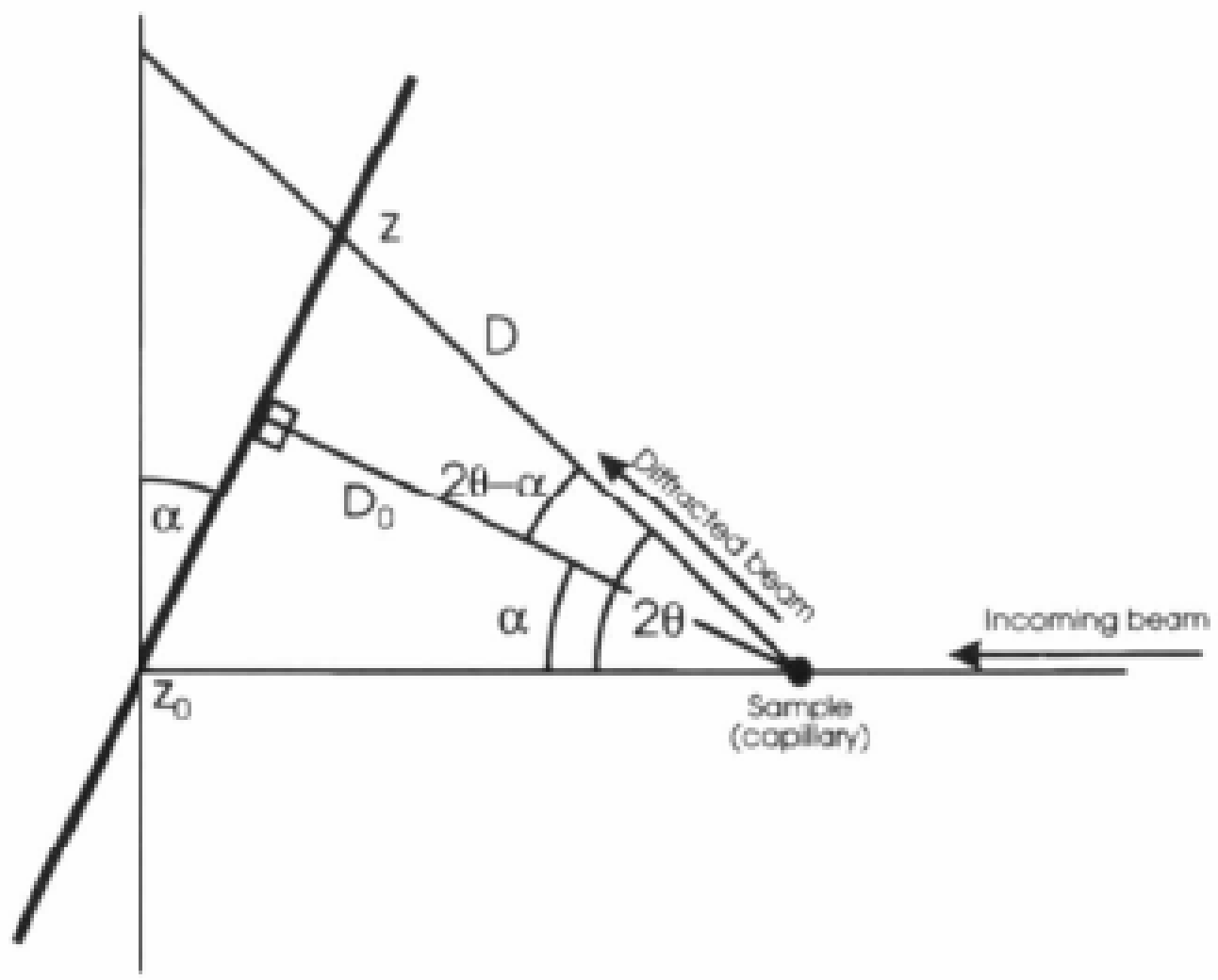

Figure 5: Schematic representation of the geometry of the X7B beamline experimental setup (27)

The parameters are $\mathrm{D}_{0}$, the distance from the sample to the imaging plate measured perpendicular to the imaging plate; $\mathrm{z}_{0}$, the zero point; $\alpha$, the tilt angle of the imaging plate; and $\lambda$, the wavelength. These parameters are determined by calibration from a known powder standard, typically $\mathrm{LaB}_{6}$ for beamline X7B.

The number of reaction sites on a catalyst surface can be determined via in situ FTIR spectroscopy with absorption of gaseous compounds (typically $\mathrm{CO}, \mathrm{CO}_{2}$ or $\mathrm{NO}$ ) onto the surface of $\mathrm{Ni}$ on alumina supported materials. Hydrogen gas also dissociates on adsorption and binds strongly to metal surfaces such as $\mathrm{Ni}$ atoms. However, $\mathrm{H}_{2}$ on a metal surface cannot be detected by infrared spectroscopy. Carbon monoxide is particularly useful as it absorbs as a molecule on both metal and metal-ion surfaces and produces strong infrared spectra on each. Fourier-transform infrared spectroscopy will 
show how $\mathrm{CO}$ probe molecules bind to Ni-exchanged hexaaluminates after reduction. There have been extensive investigations that have been performed using these probe molecules, however, there is little information regarding in situ FT-IR analysis of hexaaluminates, particularly on Ni-substituted hexaaluminates.

Galuszka et al. (28) performed an infrared study of the adsorption of $\mathrm{CO}$ as well as the coadsorption of $\mathrm{CO}$ and $\mathrm{H}_{2}$ on alumina-supported $\mathrm{Ni}$ catalysts and discovered that a total of six different IR bands were found in the spectral region of $2250-1800 \mathrm{~cm}^{-1}$ due to adsorbed $\mathrm{CO}$. The experimenters adsorbed $\mathrm{CO}$ on alumina supported $5 \% \mathrm{Ni}$ for 7 hours at 10 Torr and $150^{\circ} \mathrm{C}$ and then allowed the sample to cool to room temperature. The system was then evacuated and then the intensity and frequency of the bands were monitored. The intensity of some of the six bands was found to be influenced by the presence of $\mathrm{H}_{2}$. There were two bands that were found to occur higher than gaseous $\mathrm{CO}$. One of these bands at a wavelength of $2250 \mathrm{~cm}^{-1}$ was only present when the temperature was above $100^{\circ} \mathrm{C}$. When the same conditions were applied to an alumina supported $1 \%$ Ni sample, only one weak peak at $2050 \mathrm{~cm}^{-1}$ with accompanying shoulder appeared. This band was found to be easily removed during evacuation and only the wider shoulder peak at $2080 \mathrm{~cm}^{-1}$ remained on the surface up to $200^{\circ} \mathrm{C}$.

In a 2002 study, Bengaard and others (29) utilized $\mathrm{Ni}$ catalysts for steam reforming and studied graphite formation and methods to block the active sites. The researchers proposed that $\mathrm{CO}$ binds on $\mathrm{Ni}(111)$ and/or $\mathrm{Ni}(211)$ with a preference for three fold site on the planar $\mathrm{Ni}(111)$ surface. The investigators also stated that $\mathrm{CO}$ is usually adsorbed at temperatures below $300 \mathrm{~K}$ on the low-index $\mathrm{Ni}$ surfaces and by $\mathrm{CO}$ desorption when the temperature is increased to about $450 \mathrm{~K}$ and no $\mathrm{C}$ or $\mathrm{O}_{2}$ is left on the surface.

In the Bukhtiyarova et al. (22) study previously mentioned in Section 2.2, FTIR spectra of adsorbed probe molecules $\left(\mathrm{CO}\right.$ and $\left.\mathrm{CDCl}_{3}\right)$ on $\mathrm{SrAl}_{12} \mathrm{O}_{19}, \mathrm{BaAl}_{12} \mathrm{O}_{19}$ and $\mathrm{LaAl}_{11} \mathrm{O}_{18}$ were recorded in the region of $4000-1200 \mathrm{~cm}^{-1}$ and a resolution of $4 \mathrm{~cm}^{-1}$. The samples were pressed to self-supporting disks $\left(10-20 \mathrm{mg} \cdot \mathrm{cm}^{-2}\right)$, transferred to an IR cell and then evacuated at $500^{\circ} \mathrm{C}$ for $1.5 \mathrm{~h}$ to a residual pressure of less than $10^{-4}$ Torr. Carbon monoxide was adsorbed at $-196^{\circ} \mathrm{C}$ at pressures from 0.1 to 10 Torr.

A similar study by Kantcheva et al. (30) characterized $\mathrm{LaMnAl}_{11} \mathrm{O}_{19}$ by XRD and in situ FT-IR spectroscopy with $\mathrm{NO}$ and $\mathrm{NO} / \mathrm{O}_{2}$ probe molecules. Fourier transform 
infrared measurements were recorded with a spectrometer equipped with a liquidnitrogen cooled Mercury Cadmium Telluride (MCT) detector at a resolution of $4 \mathrm{~cm}^{-1}$. The in situ FT-IR measurements consisted of a sample of the hexaaluminate calcined at $1000^{\circ} \mathrm{C}$ for $1 \mathrm{~h}$. Self-supporting discs were created and activated in the IR cell by heating for $1 \mathrm{~h}$ in vacuum at $500^{\circ} \mathrm{C}$ and in $\mathrm{O}_{2}$ followed by evacuation for $1 \mathrm{~h}$ at $500^{\circ} \mathrm{C}$. The spectrum of the sample at ambient temperature was used as a background reference and then a flow of $99.9 \%$ pure NO gas was applied. After the subtraction of the spectrum of gaseous NO, two bands at 1861 and $1827 \mathrm{~cm}^{-1}$ were observed, and were attributed to coordinatively unsaturated $\mathrm{Mn}^{+3}$-NO species. The coadsorption of $\mathrm{NO}$ and $\mathrm{O}_{2}$ at room temperature leads to the formation of various nitro-nitrato structures, and the species were found to decompose at $350^{\circ} \mathrm{C}$ directly to $\mathrm{N}_{2}$ and $\mathrm{O}_{2}$.

$\mathrm{Hu}$ et al. (31) performed a temperature-programmed FT-IR study of the adsorption of $\mathrm{CO}$ and co-adsorption of $\mathrm{CO}$ and $\mathrm{H}_{2}$ on $\mathrm{Ni}$ on supported $\mathrm{Al}_{2} \mathrm{O}_{3}$. Although the samples were not hexaaluminates, the variety of methods utilized in the investigation of the samples is of interest. The first method was low-partial-pressure desorption of CO on the samples under vacuum in which the system was exposed to $\mathrm{CO}$ at 22 Torr for a specified time, then the system was evacuated and spectrum was recorded. The second method was temperature-programmed heating in a $\mathrm{CO}$ atmosphere at 18 Torr and spectra were recorded at different temperatures. The third technique was temperatureprogrammed-reaction in a $\mathrm{CO}$ and $\mathrm{H}_{2}$ atmosphere and performed three different ways: exposure of $\mathrm{CO}$ then $\mathrm{H}_{2}$ both at 20 Torr; exposure of $\mathrm{H}_{2}$ (15 Torr) then $\mathrm{CO}$ (20 Torr); and finally, premixed $\mathrm{CO}$ (25 Torr) and $\mathrm{H}_{2}$ (45 Torr) were introduced to the samples and spectra were recorded at different temperatures. 


\section{Chapter 3: Materials and Methodology}

\subsection{Scanning Electron Microscopy (SEM)}

The SEM images of the hexaaluminate catalysts were taken on a Hitachi S4700 Field Emission Scanning Electron Microscope located at WVU. The catalysts in the calcined state were ground with an agate mortar and pestle. However, in order to view more of the external surface area, the catalysts obtained from the reactor bed experiments by Gardner (6) were only crushed. The samples were spread onto double-sided carbon tape and then placed on an Al sample stub. The tape and stubs were supplied by Ted Pella, Inc. Upon initial capturing of the images, it was determined that the catalysts were charging badly and needed to be coated to enhance the picture quality. The samples were treated with approximately $10 \mathrm{~nm}$ of gold sputter coating. However, the morphology of the catalysts prevented a uniform coating and some charging remained. The pictures were taken under the following conditions: an accelerating voltage of $1.0 \mathrm{kV}$, a working distance of $11.9-12.4 \mathrm{~mm}$, and magnification levels at $400,5 \mathrm{k}$, and $10 \mathrm{k}$.

\subsection{X-ray Diffraction (XRD)}

Unit-cell refinement and TPR-XRD pattern measurements were conducted at the X7B beam line $(\lambda=0.9225 \AA)$ of the NSLS facility at BNL in Upton, NY. The X-ray diffraction patterns of the hexaaluminate catalysts were measured during TPR and during TPO with the POx of $\mathrm{CH}_{4}$. The diffraction patterns were measured at specific time intervals to determine if any changes in the crystal structure occur as a function of time and temperature.

The first step of XRD sample preparation was to obtain a new single-crystal sapphire capillary tube or to clean out a previously used tube using pressurized air. Each sapphire tube was open at both ends and was $50 \mathrm{~mm}$ in length with a $1.1 \mathrm{~mm}$ outer diameter and a $0.8 \mathrm{~mm}$ inner diameter. A small piece of quartz wool was spun into a small cylindrical roll and stuffed about $1 / 4$ of the distance inside the capillary tube to serve as a plug. The sample to be studied was ground to a fine powder in an agate mortar and pestle. Using a quartz capillary tube with a funnel on one end as a scoop, the sample was loaded into the sapphire tube until it filled about $2 \mathrm{~cm}$ of the length of the tube. Another quartz wool plug was placed on the other end to secure the sample in place. The sapphire 
tube was threaded through a 24 AWG Kanthal wire heating coil and loaded into the cell. Figure 5 is an image of the cell used in the experiment.

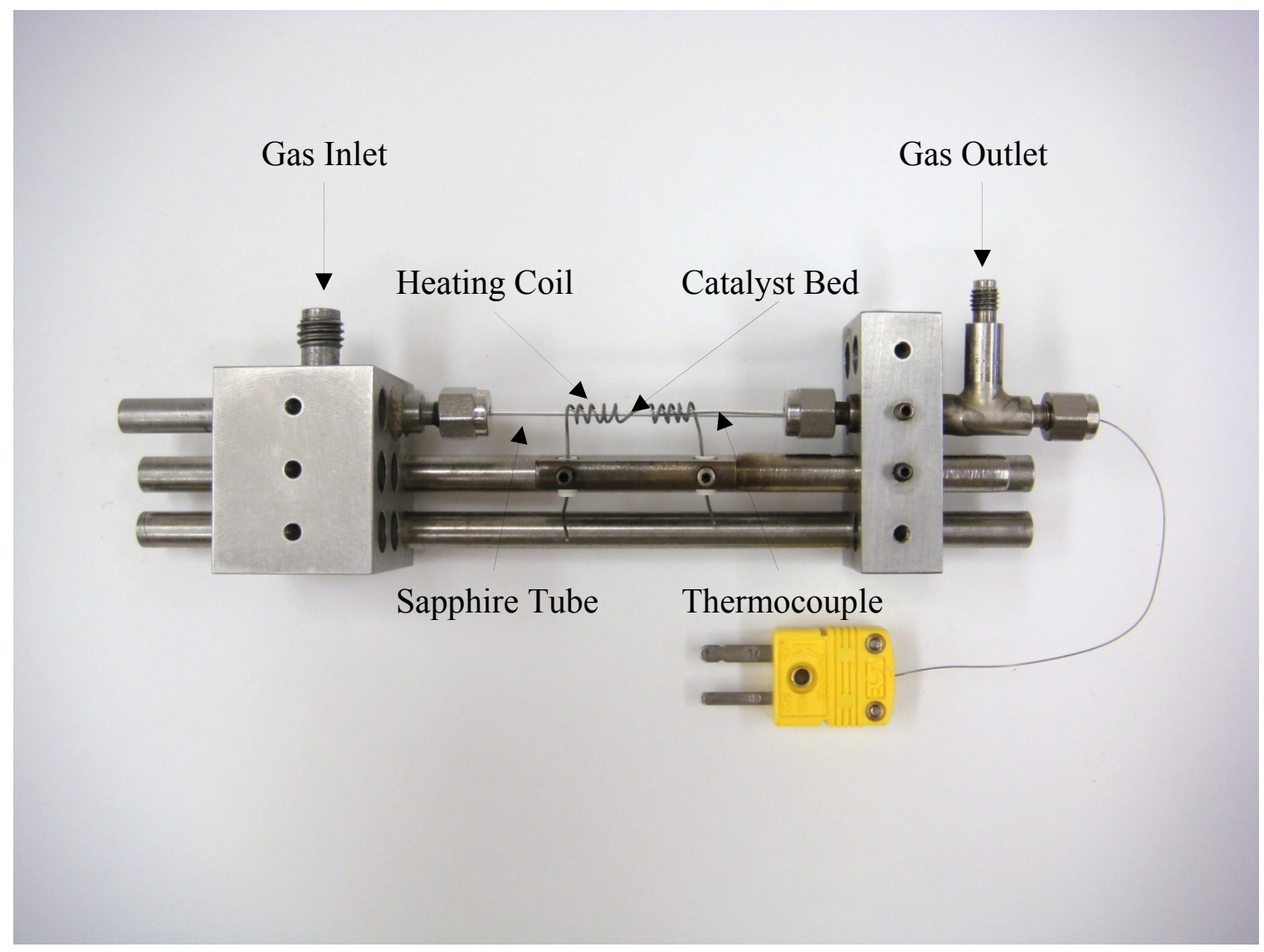

Figure 6: Experimental cell used at beamline X7B

The cell, designed and fabricated by the catalysis group at BNL, was attached to the goniometer head of the X7B beam line and positioned in the path of the beam. Tubing was connected to the cell and the sample was flushed with a gas flow of $\sim 5 \mathrm{cc} / \mathrm{min}$ flow of $5 \% \mathrm{H}_{2}-95 \% \mathrm{He}$ gas mixture acquired from Praxair. The outlet was connected to a residual gas analyzer (RGA).

\subsubsection{Unit-cell Refinement (UCR)}

Each catalyst sample was first investigated by UCR. Unit-cell refinement measurements were conducted at BNL NSLS on beam line X7B $(\lambda=0.9225 \AA)$ using a Rayonix Mar345 image plate detector to determine changes in the crystalline size and volume for the hexaaluminate catalyst samples with changing Ni-substitution level. $\mathrm{X}$ - 
ray diffraction patterns were taken at $25^{\circ} \mathrm{C}$ under He over a scanned region of 0 to $50^{\circ}$ in $2 \theta$.

The original Debye-Scherrer powder rings were integrated with FIT2D code, a dimensional data analysis software created by the European Synchrotron Research Facility, to provide conventional diffraction angle and intensity data. The FIT2D parameters for the integration of the raw synchrotron data were obtained with lanthanum hexaboride, $\mathrm{LaB}_{6}$, being used as an external calibration standard. $\mathrm{LaB}_{6}$ is also used to determine the proper tilt angle, sample-to-detector distance, wavelength, and tilting angle of the image plate. A three-dimensional chart document was obtained with a Fortran CHITOUXDS code, written by BNL X7B beamline researcher Jonathan Hanson. The time-resolved XRD pattern files were analyzed using Jade Plus 7.5, a XRD pattern processing and search-and-match software created by Materials Data Incorporated. The diffraction-pattern database used with Jade is PDF-4+ 2006 from the International Centre for Diffraction Data (ICDD). Calculation of crystal dimensions required basic symmetry information that is obtained from the PDF-4+ database.

\subsubsection{In situ Temperature-programmed Reduction and X-ray Diffraction (TPR-XRD)}

In the TPR-XRD procedure, the first temperature ramping step was to hold at $25^{\circ} \mathrm{C}$ for 2 minutes, followed by heating at a rate of $10^{\circ} \mathrm{C} / \mathrm{min}$ to $625^{\circ} \mathrm{C}$ and then at the rate of $5^{\circ} \mathrm{C} / \mathrm{min}$ until $925^{\circ} \mathrm{C}$. The temperature was held at $925^{\circ} \mathrm{C}$ for 30 minutes, and then the sample was allowed to cool to room temperature. The $5 \% \mathrm{H}_{2}-95 \% \mathrm{He}$ gas mixture continued to flush through sample during the entire run. Diffraction measurements were collected every 5 minutes using synchrotron radiation with a wavelength of $0.9225 \AA$ and a residual gas analyzer (RGA) was utilized to follow the composition of product gases. The run with $\mathrm{SrNi}_{0.4} \mathrm{Al}_{11.6} \mathrm{O}_{19}$ [52] had small variations in the heating rate in that the sample was not held at specific temperatures between heating/cooling steps.

Time-resolved or in situ XRD measurements were also conducted at BNL NSLS on beam line X7B. The entire range that was measured was of the region of 0 to $50^{\circ}$ in 20. Measurements were taken every 5 minutes, which consisted of the time needed to scan the sample and transfer the data from the imaging plate to a computer. The same 
computer programs utilized in the UCR experiments were also required for TPR-XRD data acquisition and analysis.

\subsection{In Situ Fourier-transform Infrared (FT-IR)}

To optimize the FT-IR measurement conditions characterization techniques of TPR with $5 \% \mathrm{H}_{2}$ followed by $\mathrm{CO}$ pulse chemisorption were conducted on the samples. Temperature-programmed reduction experiments, where the gas effluent is measured using a mass spectrometer, were conducted at NETL utilizing TPR under $\mathrm{H}_{2}$ to determine bond strength and reduction temperatures. This was followed by a CO pulse-absorption technique used on the reduced catalysts to determine the amount of $\mathrm{Ni}$ species on the catalyst surface. The catalyst characterization group at the NETL has the resources of a Micromeritics Autochem 2920 Catalyst Characterization System with the sample off-gas analyzed by a ThermoONIX Prima $\delta \beta$ magnetic sector mass spectrometer. These experiments are typically carried out under 5\% $\mathrm{H}_{2}-95 \% \mathrm{Ar}, 10 \% \mathrm{CO}-90 \% \mathrm{He}$ and UHP Ar gases. Pulses of $\mathrm{CO}$ are sent to the reduced catalysts until surface saturation was reached. The amount of gas adsorbed is obtained by calculating the difference between the volume of each pulse and the fraction of $\mathrm{CO}$ not adsorbed.

Fourier-transform Infrared Spectroscopy was conducted at WVU with a Thermo Nicolet Nexus 670 spectrometer loaned by NETL. The spectrometer setup is shown in Figure 6. 


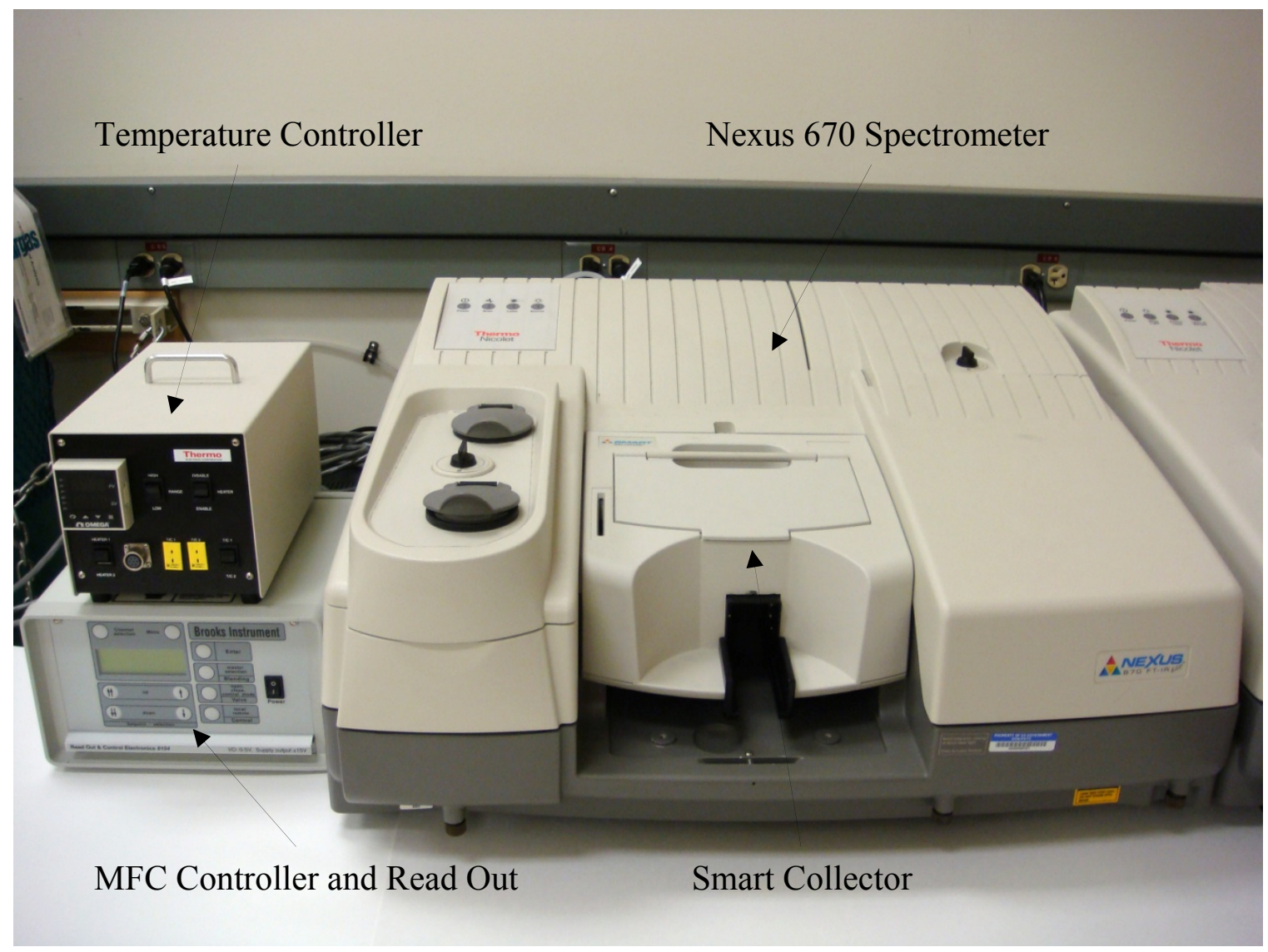

Figure 7: Thermo Nicolet Nexus 670 infrared spectrometer setup

The spectrometer was supplied with several categories of Smart Accessories that were also manufactured by Thermo Nicolet. The primary accessory utilized in the study was the Smart Collector, which is designed for infrared analysis of solid, especially powdered, samples via Diffuse Reflectance Infrared Fourier-transform Spectroscopy (DRIFTS) environmental chamber cell shown in Figure 7. Experiments were conducted with a DRIFTS Dual Environmental Chamber in which the temperature (up to $900^{\circ} \mathrm{C}$ ), pressure (from ambient to 1000 psi and $10^{-5}$ Torr) and gas phase in the environment can be controlled by the user. However, equipment tests have shown that the particular DRIFTS cell utilized in this study was restricted to a maximum temperature of $780^{\circ} \mathrm{C}$; therefore experimental conditions did not exceed $750^{\circ} \mathrm{C}$ and were often operated at $600^{\circ} \mathrm{C}$. 


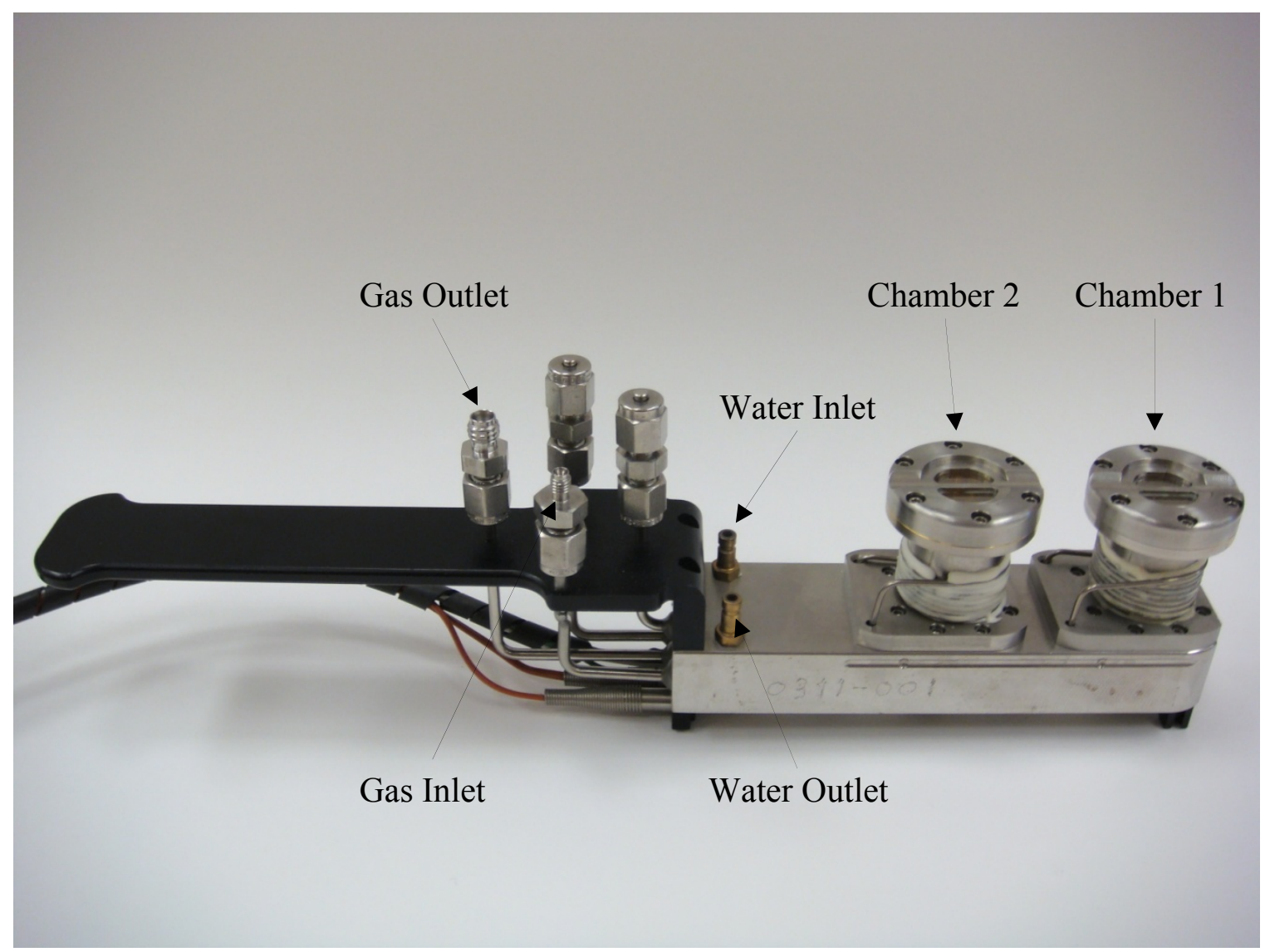

Figure 8: DRIFTS dual environmental chamber for smart collector

Inside each chamber is a ceramic heater sample cup with thermocouple to monitor the temperature of the sample. A Thermo electronics temperature read-out with an Omega CN8500 series temperature controller was utilized to control the temperature and ramping rate of the sample cups in the dual chambers. To prevent the environmental chamber from overheating and damaging the chamber window, O-ring seals and/or smart accessory, a VWR recirculation chiller was connected to the system and was set to cool the water at $15^{\circ} \mathrm{C}$. A FT-IR purge gas generator manufactured by Parker Balston Analytical Gas Systems, model 75-52, was installed to remove water and carbon dioxide from purge air and supply a dry, high-purity stream of air flow (50 psi) to the Nexus 670 spectrometer.

The gas feed for the dual-chambered DRIFTS cell was adjacent to the spectrometer. The process flow diagram (PFD) for the setup of the gas feed for the dual chambered DRIFTS cell is illustrated as Figure 8. The unit has three separate (1/8" 316 stainless steel tubing) feed lines that are each passed through a $0.5 \mu \mathrm{m}$ filter and then into 
a Brooks 5850E mass flow controller (MFC). The MFCs are controlled by a Brooks Instrument Read Out \& Control Electronics 0154 unit. Line 1 contains 5\% $\mathrm{H}_{2}$ gas (balance $\mathrm{He}$ ) and was calibrated by Brooks for $0-20 \mathrm{sccm}$ of He flow. Line 2 is set up for pure He gas and calibrated by Brooks for $0-50 \mathrm{sccm}$ of He flow. Line 3 is attached to a cylinder of 500 ppm CO gas (balance He) and was calibrated by Brooks for 0-20 sccm of He flow. All of the gas cylinders were supplied by Airgas, Inc. Following the MFCs, line 1 passes through a check valve and connects to a 3 -way valve that directs flow to the dual environmental chamber or to a ventilation hood. Lines 2 and 3 each passed through check valves and connect to a 6-port sampling valve and finally connect to 3-way valves leading to the chamber inlet. The 6-port valve allows either continuous flow or a controlled volume sampling flow of $500 \mathrm{ppm}$ CO gas to the sample in the DRIFTS cell. The gases or combinations of gases fed into the inlet of the dual environmental chambers and the outlet connected to the inlet line of a mechanical pump. The pump was used to evacuate the system before changing the gas flow through the DRIFTS cell. The outlet of the pump was plumbed into a ventilation hood. Figure 9 is an image of the setup fabricated for this investigation.

Due to the high reduction temperatures of hexaaluminate samples, the DRIFTS cell was unable to reduce the calcined samples sufficiently, and pretreatment was required. The hexaaluminates were placed in ceramic boats inside a tubular reactor and heated to $1000^{\circ} \mathrm{C}$ under a $50 \mathrm{cc} / \mathrm{min} 5 \% \mathrm{H}_{2}-95 \% \mathrm{He}$ mixture at a rate of $10^{\circ} \mathrm{C} / \mathrm{min}$. The samples were held at $1000^{\circ} \mathrm{C}$ for $8 \mathrm{~h}$ and allowed to cool. After being flushed with He for $30 \mathrm{~min}$, the samples were passivated with $3 \% \mathrm{O}_{2}-97 \% \mathrm{He}$ gas mixture for $1 \mathrm{~h}$ at room temperature. Passivation of the catalysts creates a thin oxide layer on the sample surface that can later be re-reduced under less extreme conditions. Upon removal of the tubular reactor, the samples were found to remain gray in color, indicating the passivation procedure was successful.

The passivated samples were ground into a fine powder via an agate mortar and pestle. About $0.3 \mathrm{~g}$ of the sample was loaded into one of the sample cups of the DRIFTS cell and the sample surface was leveled evenly with the lip of the ceramic cup. The samples were carefully packed in the ceramic cup due to the fact that loose samples could be blown out by the flow of gases and compacted samples would restrict the flow. A secondary sample or an $\mathrm{Al}_{2} \mathrm{O}_{3}$ standard was placed in the second sample cup to flow 


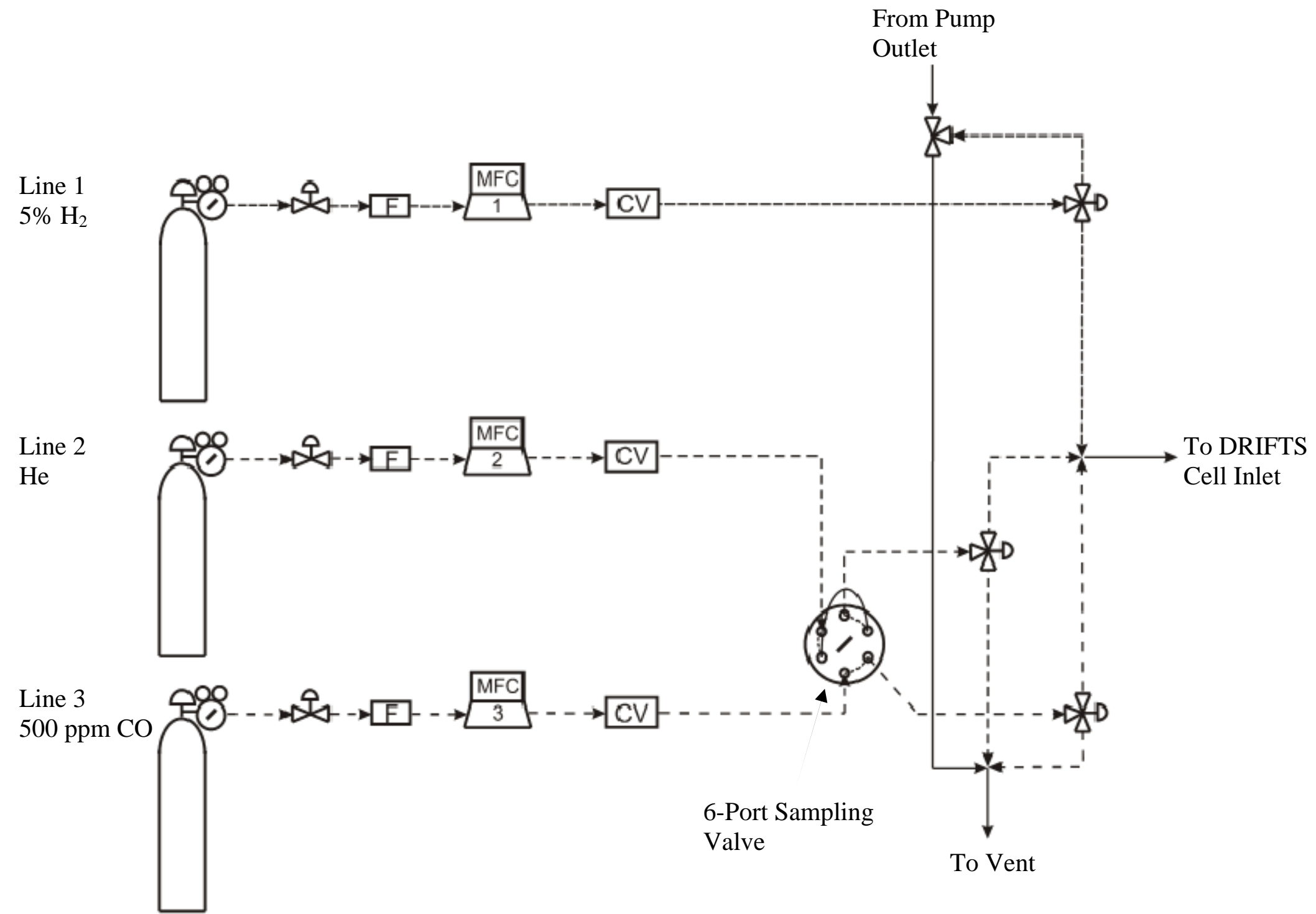

Figure 9: Process flow diagram of setup of the gas feed inlet of dual environmental chamber cell F, filter; MFC, mass flow controller; $\mathrm{CV}$, check valve 


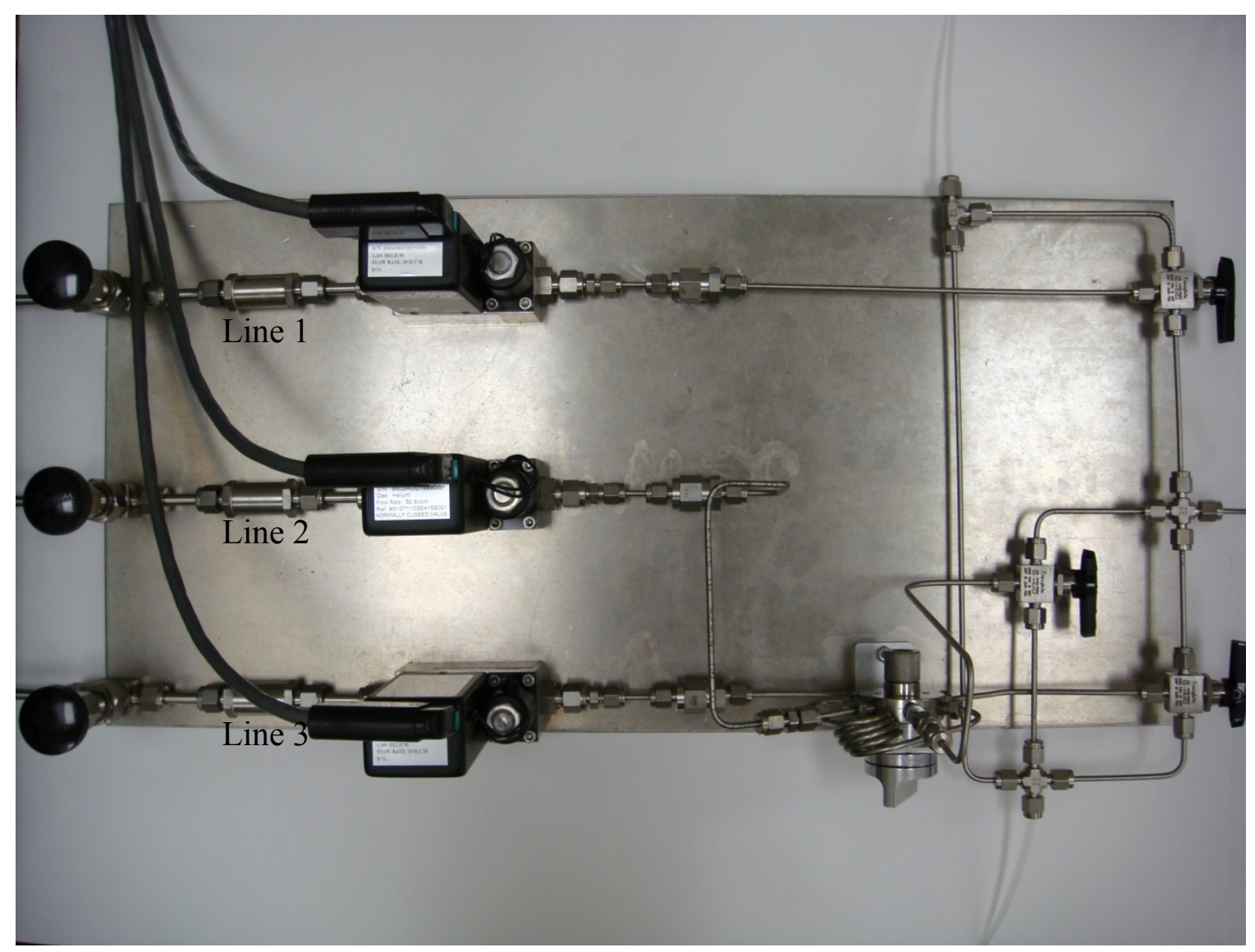

Figure 10: Setup of the gas feed inlet of dual environmental chamber cell

gases across both cups more evenly. The O-rings were covered with vacuum grease to ensure a tight seal and the optic chamber lids were fastened to the DRIFTS cell. The next step of sample preparation was to connect the feed gas and cooling water lines to the cell. Finally, the system and lines were tested for leaks.

The passivated samples were heated until reaching the set temperature of 600$750^{\circ} \mathrm{C}$ under $40 \mathrm{cc} / \mathrm{min} 5 \% \mathrm{H}_{2}-95 \% \mathrm{He}$ at a rate of $10^{\circ} \mathrm{C} / \mathrm{min}$ and held at maximum temperature for $2 \mathrm{~h}$. After the holding period the samples were allowed to cool and the gases were evacuated via a mechanical pump for $15 \mathrm{~min}$. A scan of the sample was then taken by the FT-IR to serve as a background for the scans after CO exposure. A $40 \mathrm{cc} / \mathrm{min}$ flow of $500 \mathrm{ppm}$ CO-balance He was applied to the chamber and scans were taken after 2, 5, 10, 15, 20, 25 and $30 \mathrm{~min}$ of exposure to CO. After $30 \mathrm{~min}$, the chamber was evacuated via a mechanical pump and scans were taken at 5,10 and 15 min after exposure to determine what species remained bonded to the surface of the catalysts. 
Additional instructions for FT-IR operations are located in the Section A.1 of the Appendix.

\subsection{Safety}

The chemicals used in this study are $5 \% \mathrm{H}_{2}$ gas (balance $\mathrm{He}$ ), $500 \mathrm{ppm} \mathrm{CO}$ gas (balance $\mathrm{He}$ ), $5 \% \mathrm{CH}_{4}-2.5 \% \mathrm{O}_{2}-92.5 \%$ (balance $\mathrm{He}$ ) gas, $\mathrm{He}$ gas, and liquid nitrogen. Material safety data sheets (MSDS) were obtained for each of the chemicals used in this study. Helium and $\mathrm{H}_{2}$ can act as simple asphyxiants and $\mathrm{H}_{2}$ is widely known to be highly flammable. Carbon monoxide is toxic upon inhalation and has warnings regarding its flammability. Although the concentrations of $\mathrm{H}_{2}$ and $\mathrm{CO}$ utilized in this investigation are below minimum flammability levels and cannot burn, special care was taken to keep them away from flames and other ignition sources. Exit lines are plumbed into the ventilation hood. Liquid $\mathrm{N}_{2}$ can be an asphyxiant and may cause frostbite upon contact with skin. Liquid $\mathrm{N}_{2}$ transport requires the use of a Dewar. All cylinders contain gases and/or liquids under high pressure and must be handled with care. Detailed MSDS data on hexaaluminates is not readily available, however like most powders, the hexaaluminates are assumed to be irritants to the eyes, skin and respiratory system; thus all handling of the samples was conducted in a ventilation hood with proper safety attire.

Safety apparatus including laboratory coats, glasses, goggles, masks, latex gloves and thermal gloves were worn as necessary or as required by safety rules when operating equipment, handling chemicals and/or performing experiments. The laboratory is equipped with ventilation hoods, fire extinguishers and blankets, chemical safety showers, eye-wash stations and first aid kits. Material safety data sheets for all chemicals utilized and/or stored in the laboratory in addition to a contact list for emergency response is posted at each entrance of the laboratory. 


\section{Chapter 4: Results and Discussions}

\subsection{SEM}

The hexaaluminate catalysts prepared at NETL were examined by scanning electron microscopy at WVU. Both series were investigated via the procedure and conditions as described in Section 3.1. Figures 10, 11 and 12 illustrate the $\mathrm{LaNi}_{0.4} \mathrm{Al}_{11.6} \mathrm{O}_{19} \quad$ [35], $\quad \mathrm{SrNi}_{0.4} \mathrm{Al}_{11.6} \mathrm{O}_{19}$ [52] and $\mathrm{BaNi}_{0.4} \mathrm{Al}_{11.6} \mathrm{O}_{18.8}$ [75] samples respectively, each at a magnification level of $10,000 \mathrm{x}$. There does not seem to be a uniform shape to describe all of the samples and all appear to be a cluster of hexaaluminate particles. The SEM images of the mirror-cation-varied samples are very similar to each other; however there seems to be slight differences on how the particles agglomerate. The $\mathrm{LaNi}_{0.4} \mathrm{Al}_{11.6} \mathrm{O}_{19}$ [35] sample seems to have morphology similar to a coral reef. The $\mathrm{SrNi}_{0.4} \mathrm{Al}_{11.6} \mathrm{O}_{19}$ [52] sample appears to be more like a collection of breakfast-cereal flakes. $\mathrm{BaNi}_{0.4} \mathrm{Al}_{11.6} \mathrm{O}_{18.8}[75]$ has particles that might be described as having the appearance of steamed rice.

The series of Ni-substituted Ba hexaaluminates was also examined by SEM and the images of $\mathrm{BaNi}_{0.8} \mathrm{Al}_{11.2} \mathrm{O}_{18.6}[118 \mathrm{~B}]$ and $\mathrm{BaNiAl}_{11} \mathrm{O}_{18.5}[119 \mathrm{~B}]$ are provided in Figures 13 and 14 respectively. There appears to be little to no difference between the morphology of the different Ni-substituted Ba catalysts. The similarity between samples indicates that the percentage of $\mathrm{Ni}$ is low enough that variations do not have a substantial effect on surface morphology. Figure 15 is an image of $\mathrm{BaAl}_{12} \mathrm{O}_{19}[38 \mathrm{C}]$ which does not contain any $\mathrm{Ni}$. The $\mathrm{BaAl}_{12} \mathrm{O}_{19}$ [38C] sample appears to have thinner flaky, sometimes needle-like architecture and has a different morphology than the other hexaaluminates that contain Ni. 


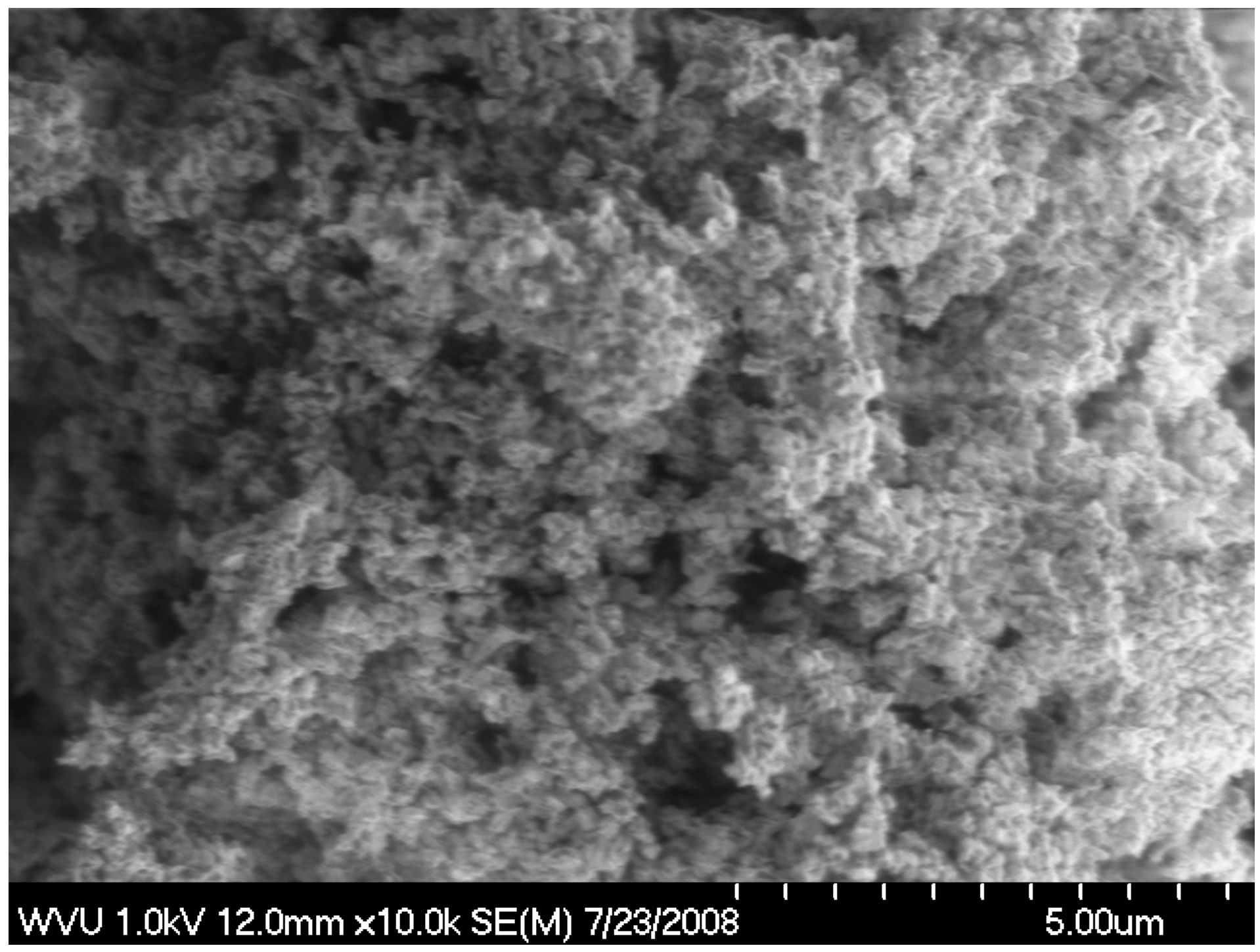

Figure 11: SEM image of calcined $\mathrm{LaNi}_{0.4} \mathrm{Al}_{11.6} \mathrm{O}_{19}[35]$ 


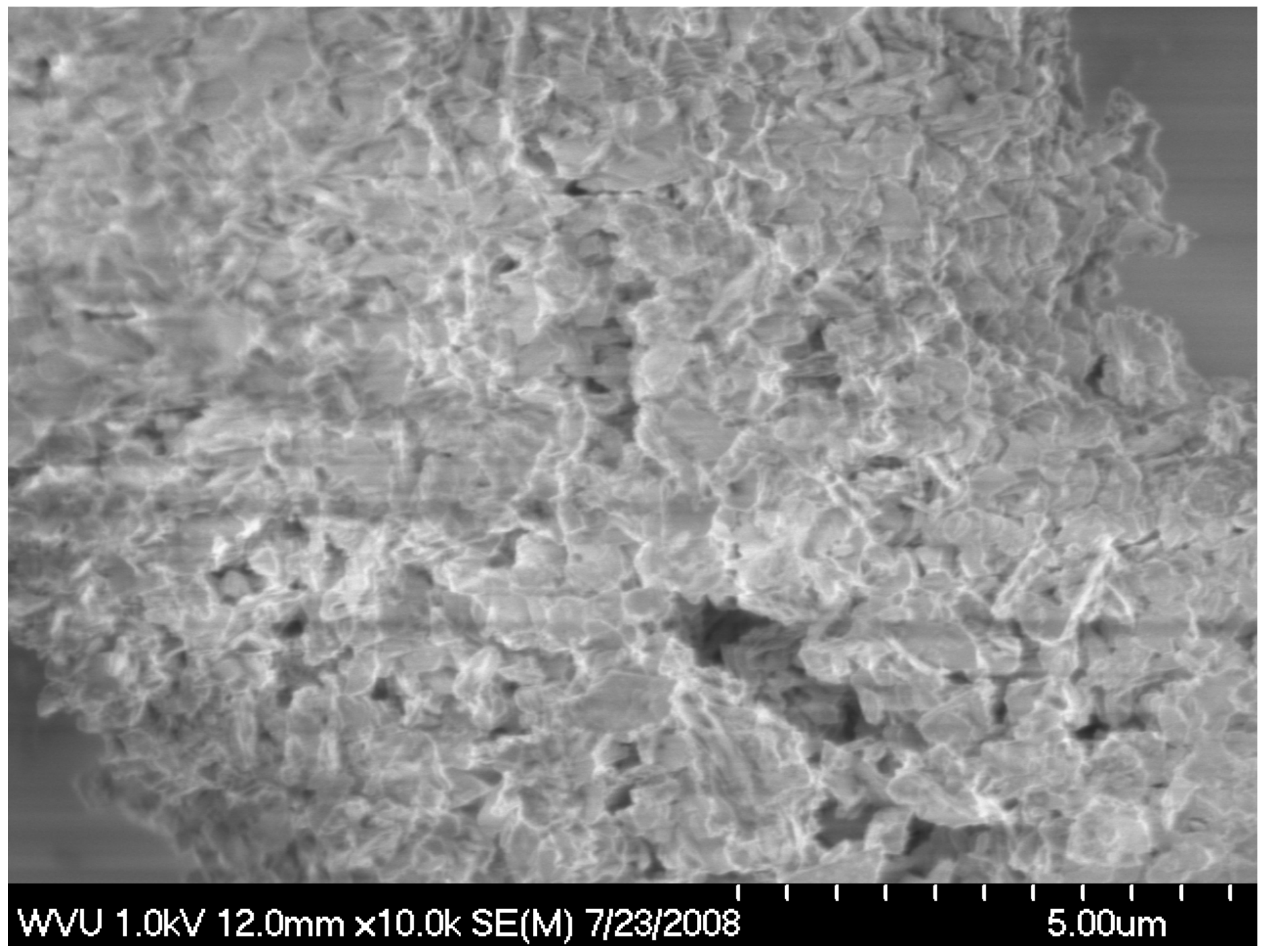

Figure 12: SEM image of calcined $\mathrm{SrNi}_{0.4} \mathrm{Al}_{11.6} \mathrm{O}_{19}[52]$ 


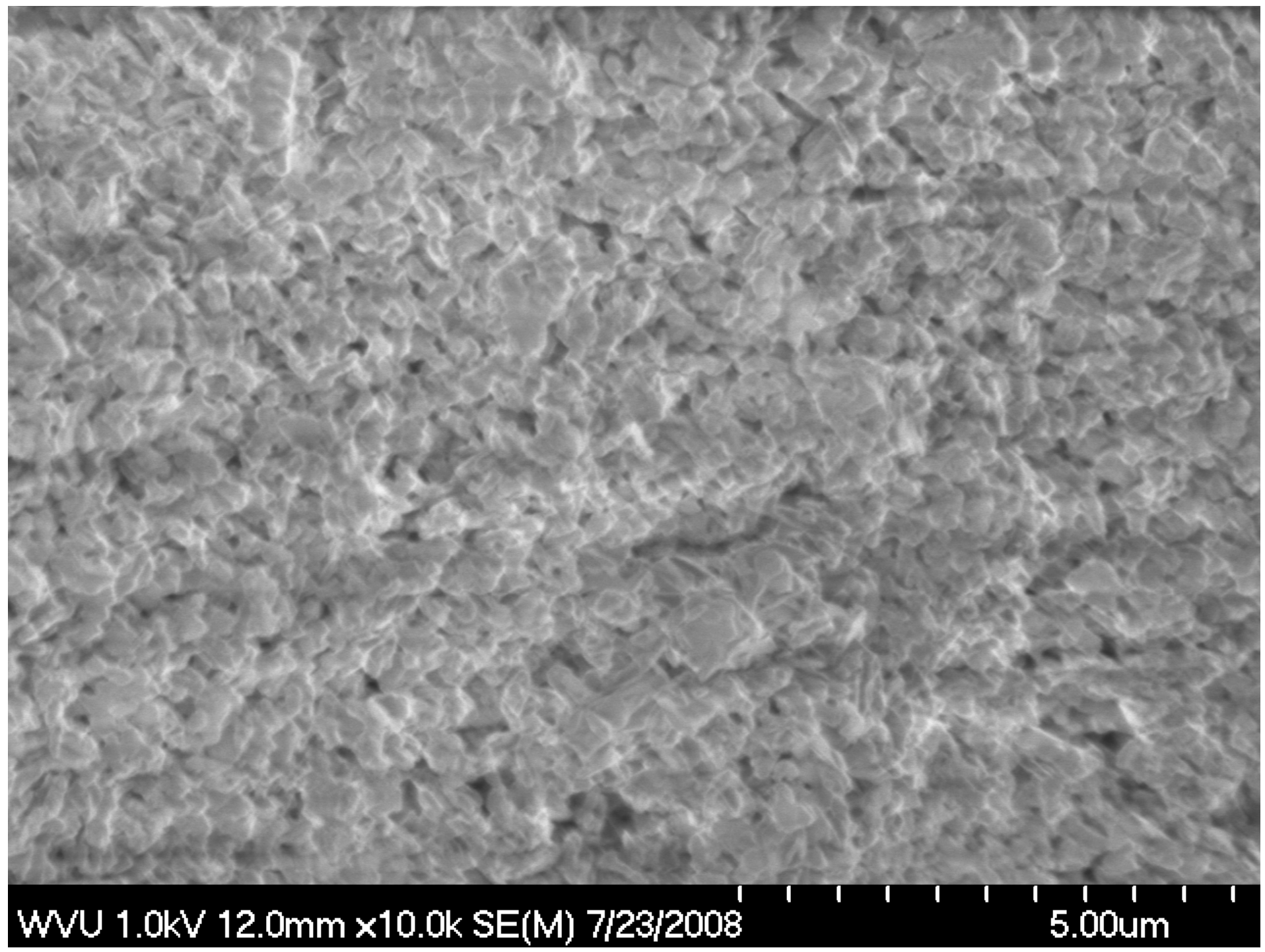

Figure 13: SEM image of calcined $\mathrm{BaNi}_{0.4} \mathrm{Al}_{11.6} \mathrm{O}_{18.8}$ [75] 


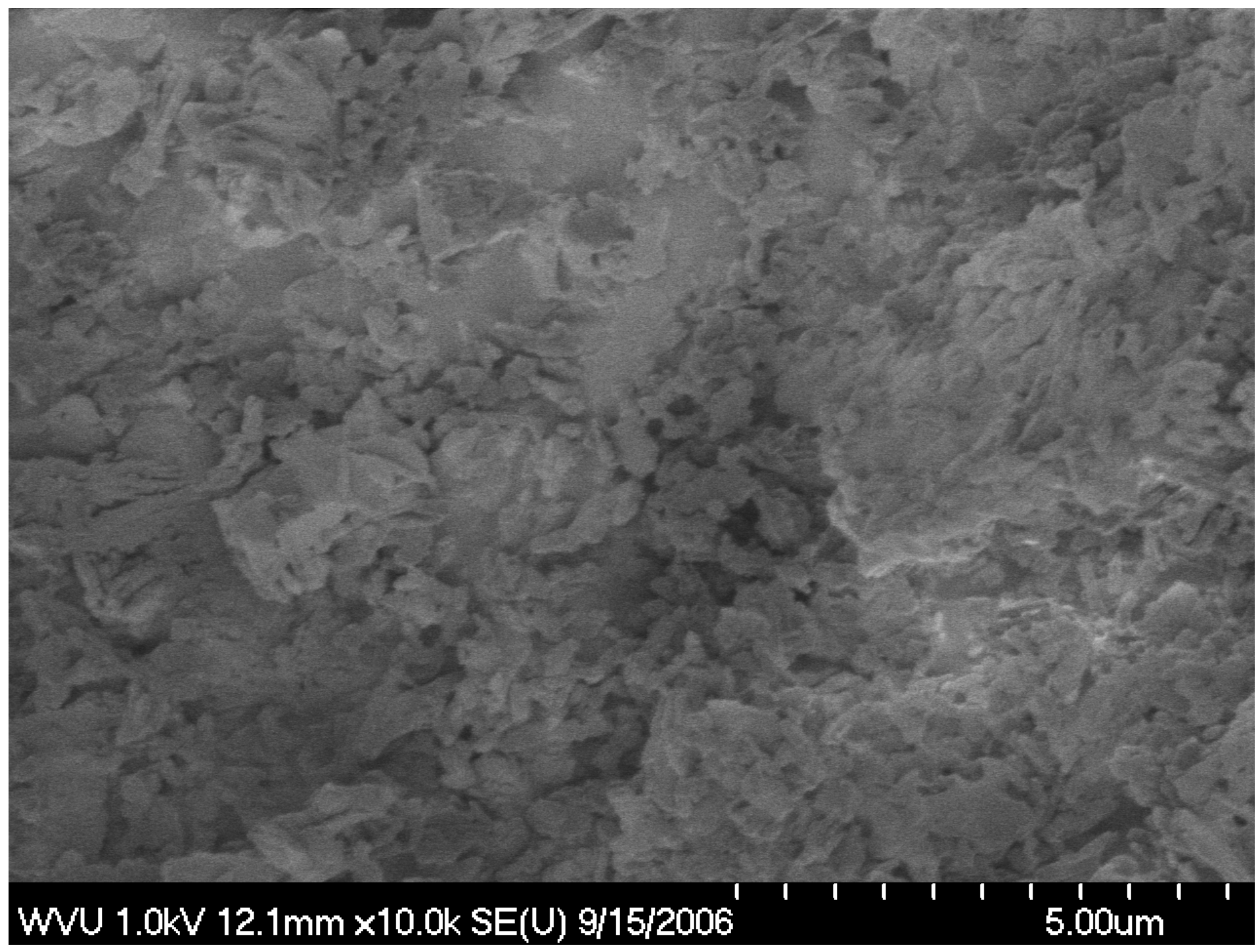

Figure 14: SEM image of calcined $\mathrm{BaNi}_{0.8} \mathrm{Al}_{11.2} \mathrm{O}_{18.6}[118 \mathrm{~B}]$ 


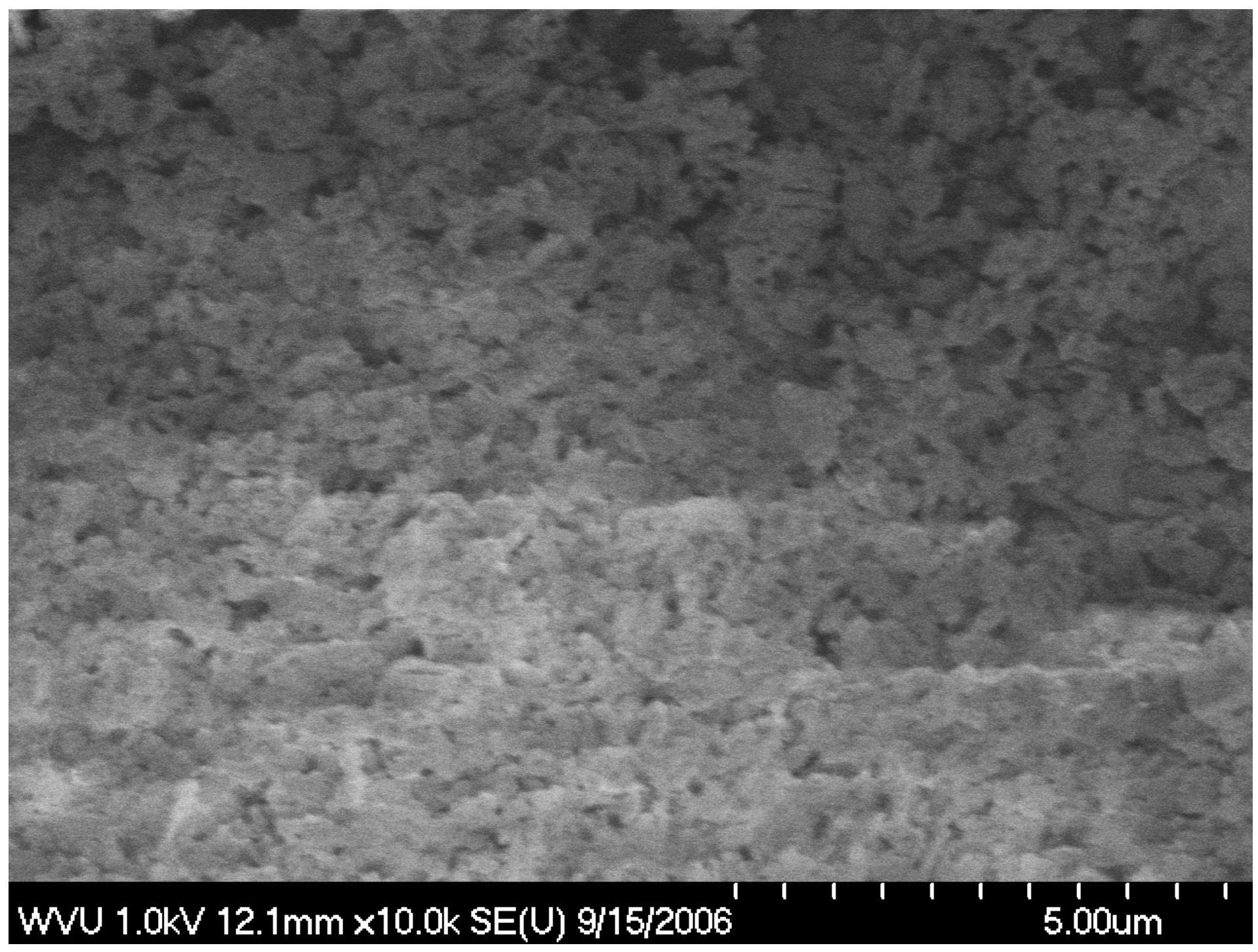

Figure 15: SEM image of calcined $\mathrm{BaNiAl}_{11} \mathrm{O}_{18.5}[119 \mathrm{~B}]$ 


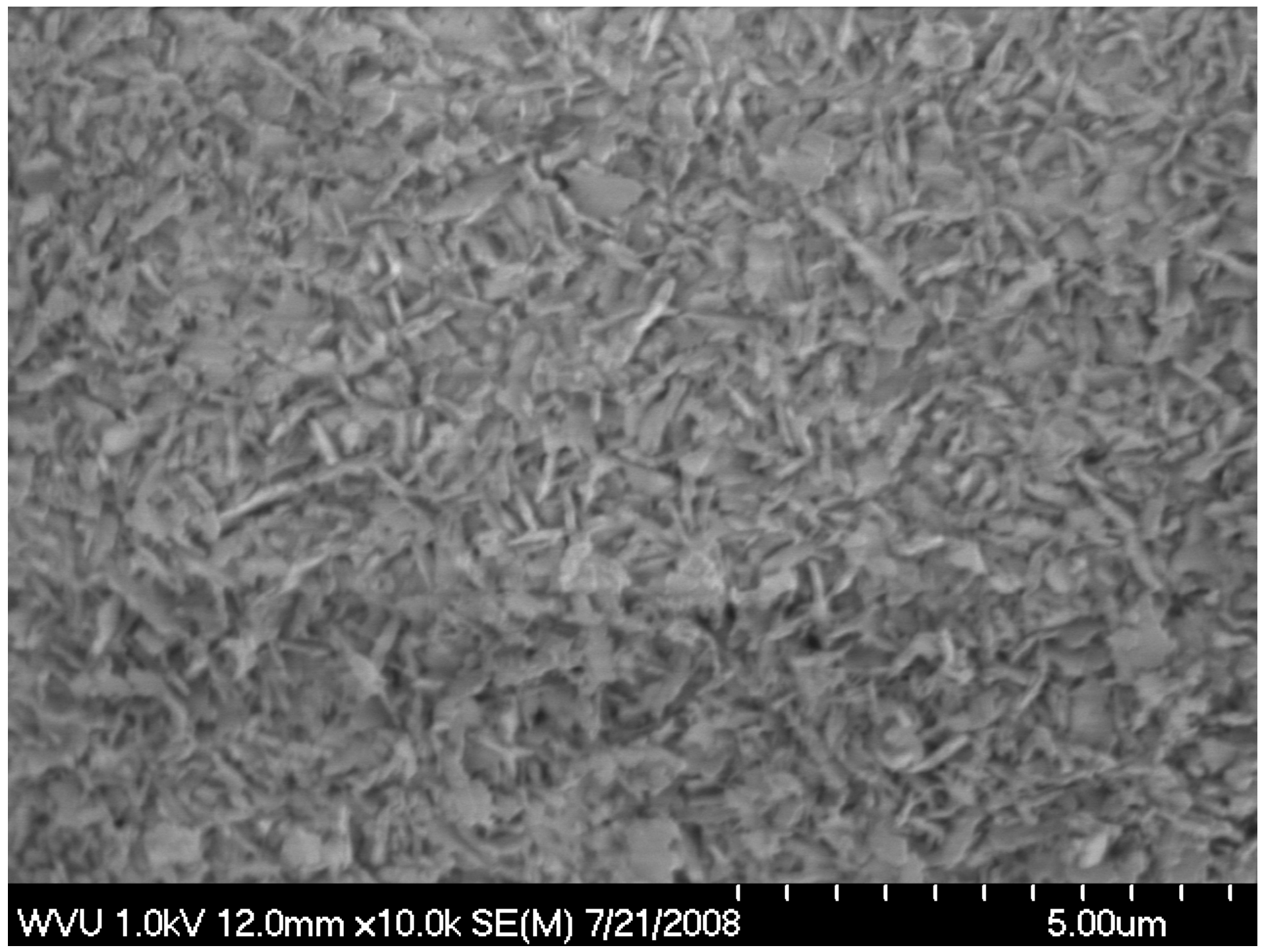

Figure 16: $\mathrm{SEM}$ image of calcined $\mathrm{BaAl}_{12} \mathrm{O}_{19}[38 \mathrm{C}]$ 
The Ni-substituted Ba hexaaluminate series of catalysts were used for TPO of the POx of $\mathrm{CH}_{4}$ at NETL (18), as described in Section 2.2, and samples were obtained from different locations in the catalyst bed. The leading edge of the catalyst bed continued to have the original blue color catalyst particles, whereas the particles further into the reactor turned from blue to gray. Samples taken from both regions of the reactor bed were acquired and analyzed via SEM to discern any differences. Crushing the particles showed uniform coloration throughout, which is an indication that the samples were completely reduced and did not have diffusion effects.

Figure 16 shows the blue phase of $\mathrm{BaNiAl}_{11} \mathrm{O}_{18.5}$ [119B-blue] and Figure 17 shows the gray phase for the same material. Examination of the SEM images could not distinguish any substantial differences between the blue and gray samples, with all of the particles closely resembling the fresh materials observed previously. 


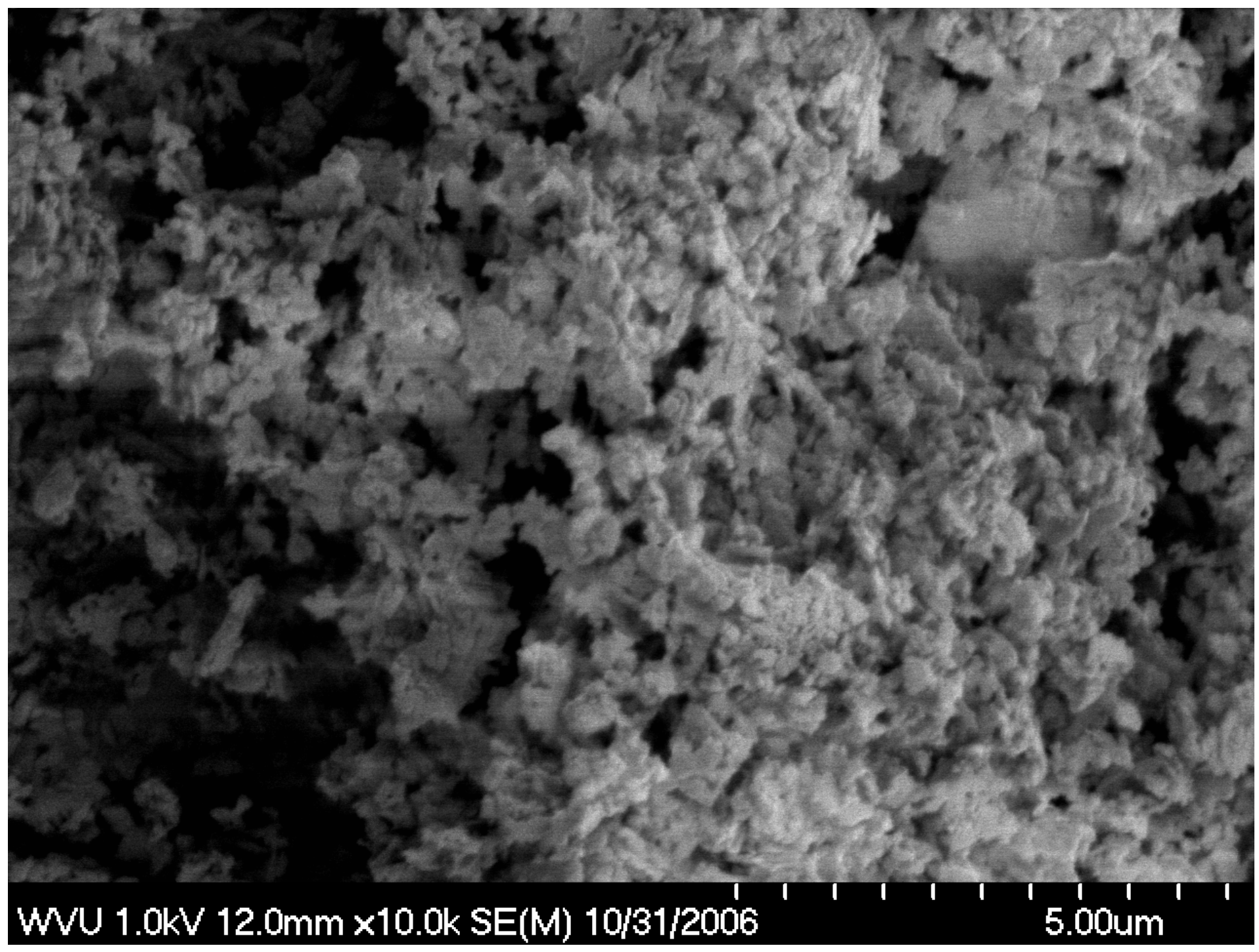

Figure 17: SEM image of blue particle of $\mathrm{BaNiAl}_{11} \mathrm{O}_{18.5}\left[119 \mathrm{~B}\right.$-blue] after $\mathrm{CH}_{4} \mathrm{PO}_{\mathrm{x}}$ 


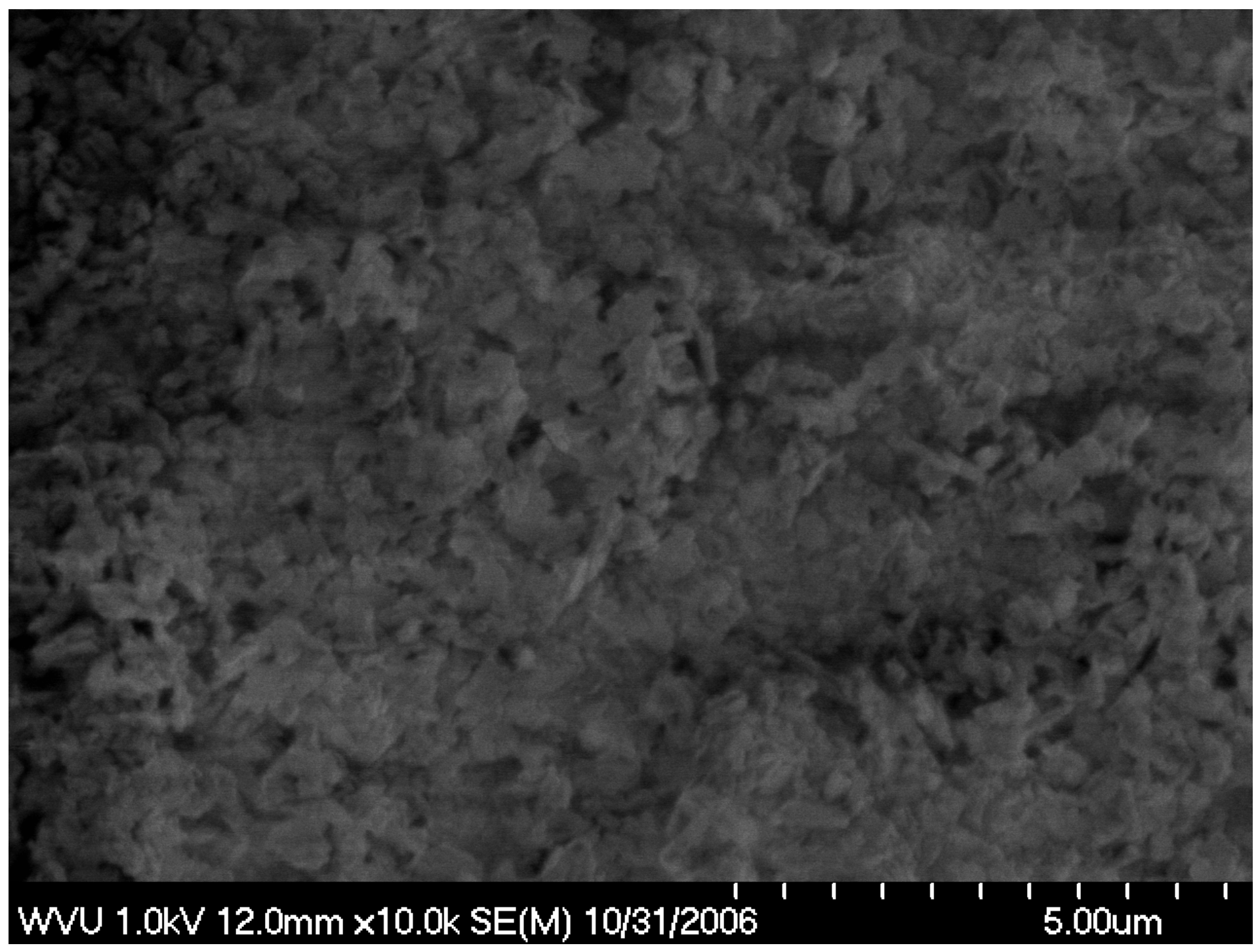

Figure 18: SEM image of gray particle of $\mathrm{BaNiAl}_{11} \mathrm{O}_{18.5}$ [119B-gray] after $\mathrm{CH}_{4} \mathrm{PO}_{\mathrm{x}}$ 


\subsection{XRD}

\subsubsection{UCR}

Unit-cell refinement was performed on all of the fresh hexaaluminate catalyst samples with the XRD scan taken at $25^{\circ} \mathrm{C}$. These samples were run in $0.5 \mathrm{~mm}$ quartz capillary tubes. The wavelength of the beamline was calculated using $\mathrm{LaB}_{6}$ external standards and determined to be $0.9209 \AA$ for this series of measurements. The image plate data of the scans were evaluated via Fit2D and imported into Jade to determine the crystal lattice parameters of the samples. There are no Ni-substituted hexaaluminates located in the ICDD database so non-substituted hexaaluminate formulas were used. The XRD diffraction patterns for each of the three cation hexaaluminate samples types were chosen from the best results of the search and match analysis in Jade using the ICDD database. The ICDD crystal lattice parameters of the chosen patterns are displayed in Table 3.

Table 3: ICDD Crystal Lattice Dimensions of Baseline Patterns

\begin{tabular}{|c|c|c|c|}
\hline $\begin{array}{c}\text { Name } \\
{[\mathbf{I C D D} \#]}\end{array}$ & $\boldsymbol{a , b}(\mathbf{\AA})$ & $\boldsymbol{c}(\mathbf{\AA})$ & Volume $\left.\mathbf{( \AA}^{\mathbf{3}}\right)$ \\
\hline $\begin{array}{c}\mathrm{LaAl}_{11} \mathrm{O}_{18} \\
{[00-033-0699]}\end{array}$ & 5.561 & 22.041 & 590.29 \\
\hline $\begin{array}{c}\mathrm{LaAlO}_{3} \\
{[00-031-0022]}\end{array}$ & 5.364 & 13.110 & 326.67 \\
\hline $\begin{array}{c}\mathrm{SrAl}_{12} \mathrm{O}_{19} \\
{[04-007-6069]}\end{array}$ & 5.562 & 21.972 & 588.66 \\
\hline $\begin{array}{c}\mathrm{Ba}_{0.75} \mathrm{Al}_{11} \mathrm{O}_{17.25} \\
{[04-010-2927]}\end{array}$ & 5.582 & 22.715 & 612.95 \\
\hline
\end{tabular}

The XRD patterns for the La, Sr and Ba Ni-modified hexaaluminate catalysts as well as the peak information of the standards chosen from ICDD are illustrated as Figures 18,19 and 20. 


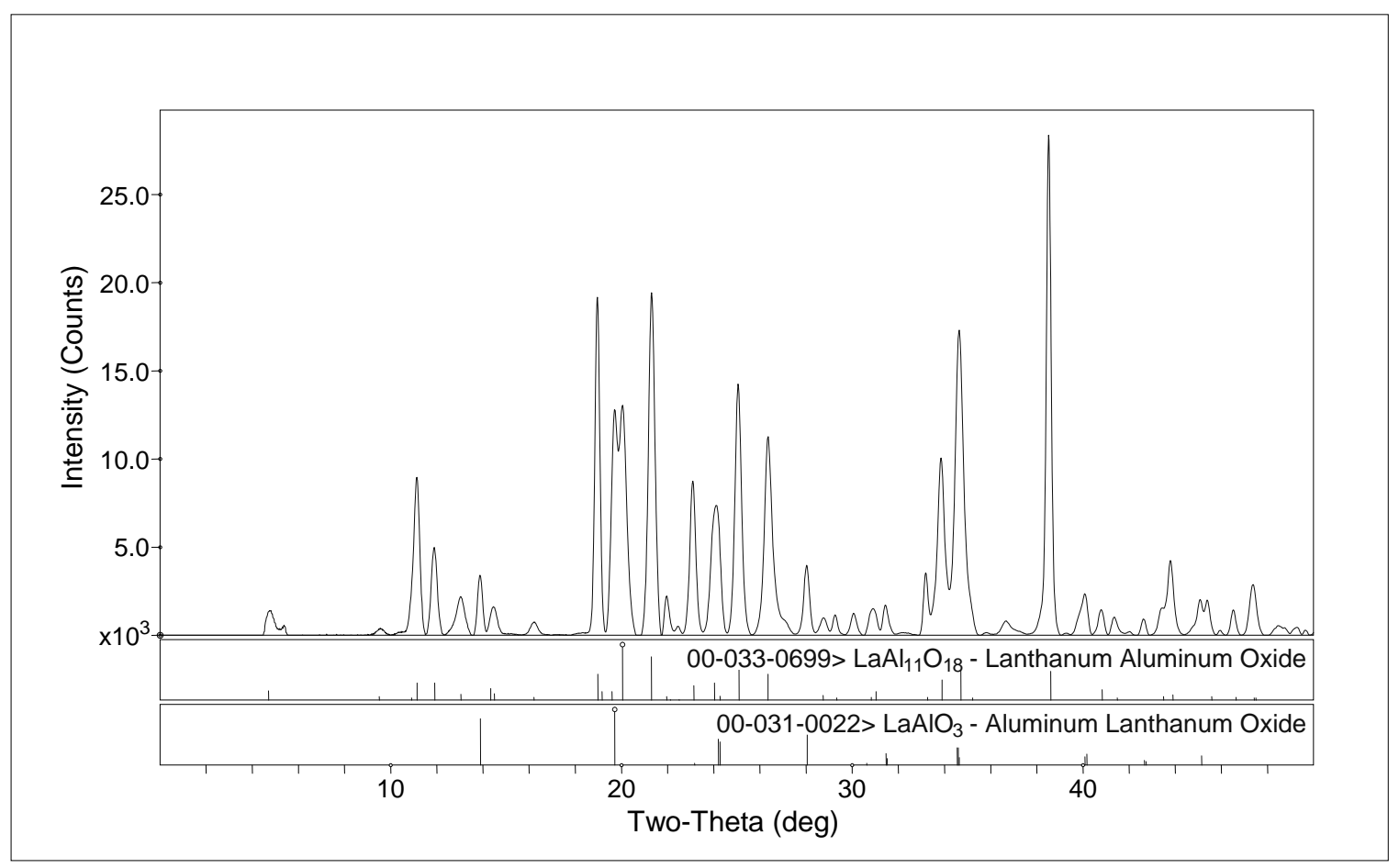

Figure 19: X-ray diffraction pattern of fresh $\mathrm{LaNi}_{0.4} \mathrm{Al}_{11.6} \mathrm{O}_{19}[35]$

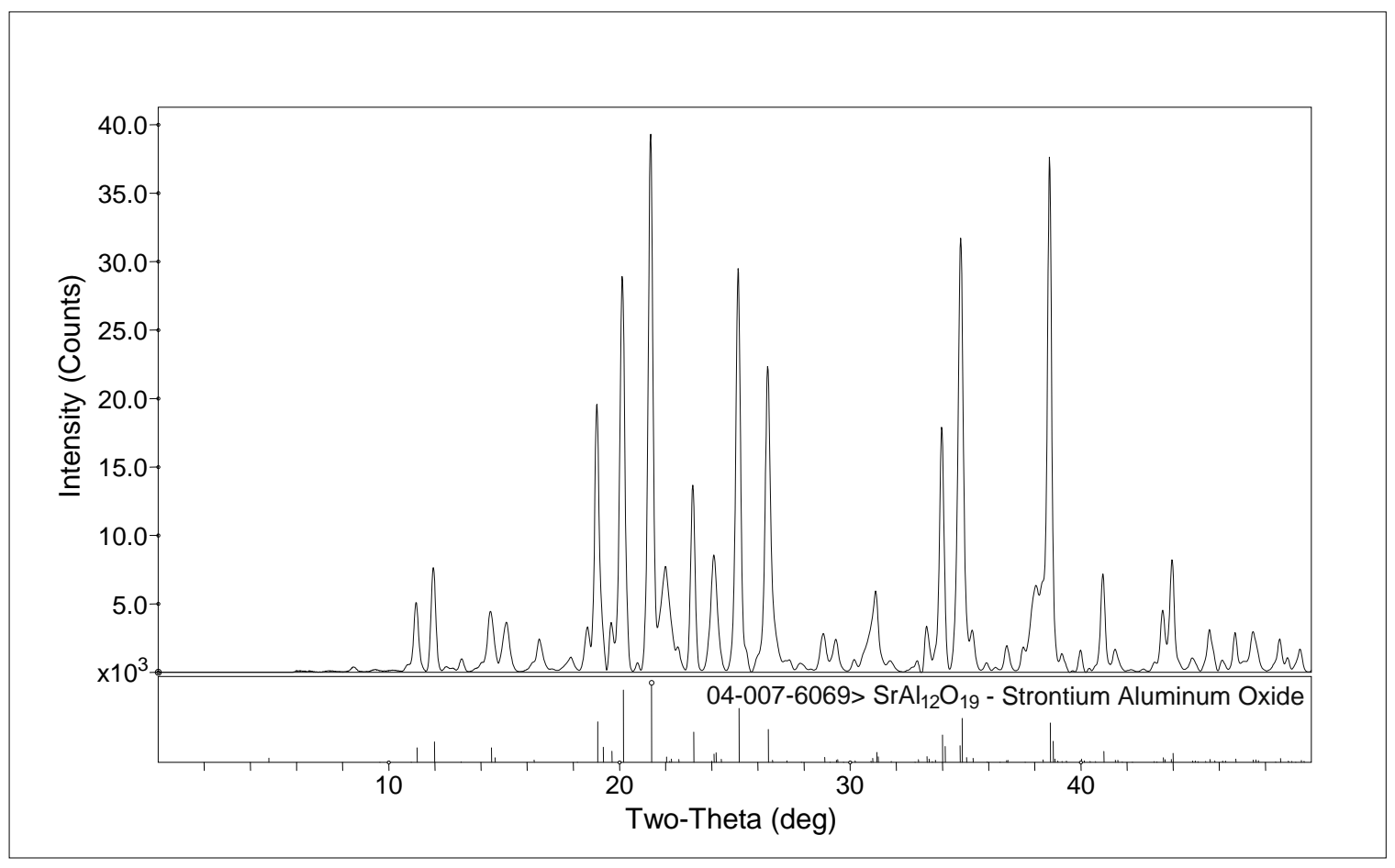

Figure 20: X-ray diffraction pattern of fresh $\mathrm{SrNi}_{0.4} \mathrm{Al}_{11.6} \mathrm{O}_{19}[52]$ 


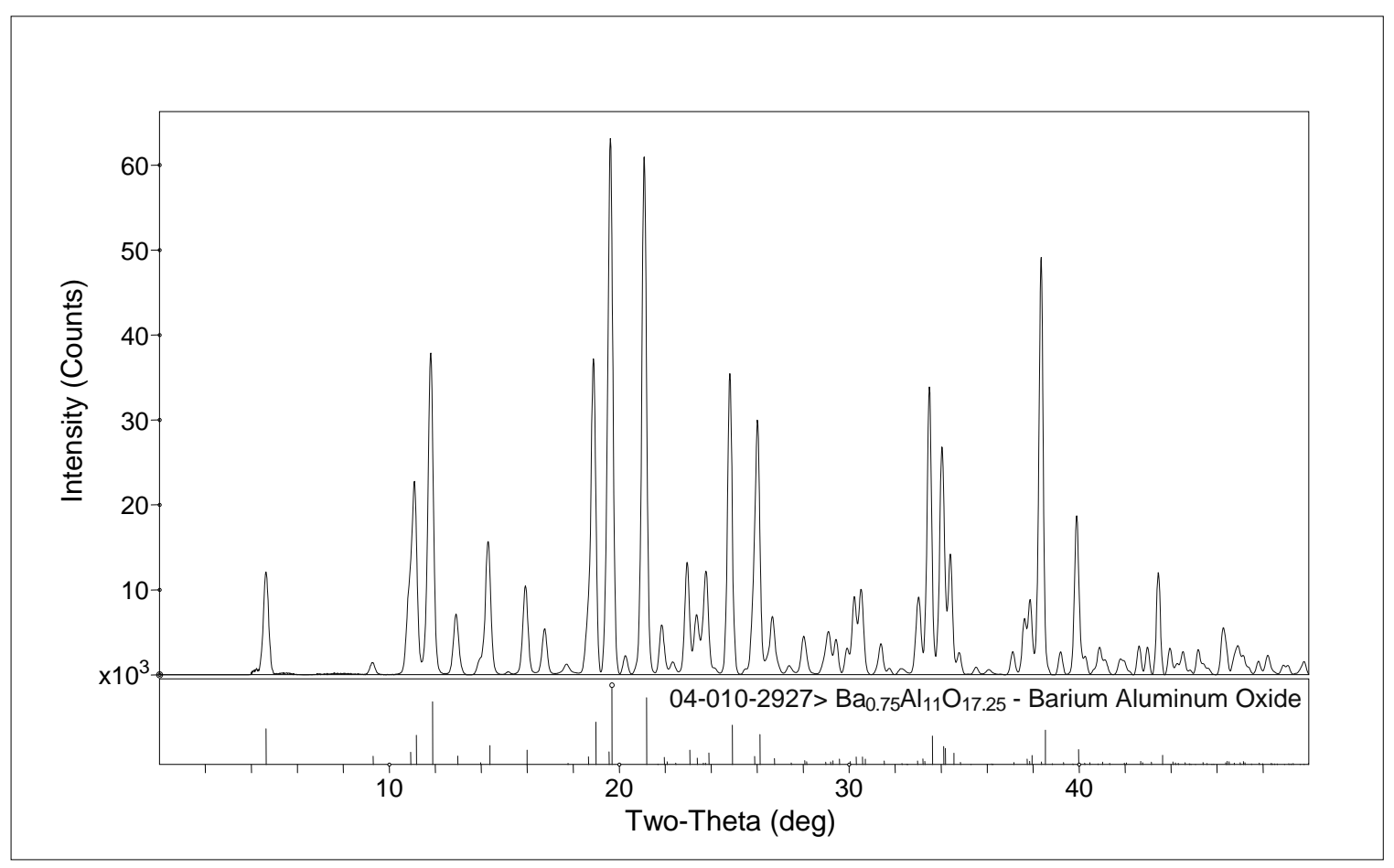

Figure 21: X-ray diffraction pattern of fresh $\mathrm{BaNi}_{0.4} \mathrm{Al}_{11.6} \mathrm{O}_{18.8}[75]$

In Figure 18, $\mathrm{LaNi}_{0.4} \mathrm{Al}_{11.6} \mathrm{O}_{19}[35]$ appears to have an impurity phase of $\mathrm{LaAlO}_{3}$. At a wavelength of $0.9209 \AA, \mathrm{LaNi}_{0.4} \mathrm{Al}_{11.6} \mathrm{O}_{19}$ [35] is found to have characteristic peaks located at 11.1, 18.9, 19.7, 20.0, 21.3, 23.1, 25.0, 26.3, 33.8, 34.6 and $38.5^{\circ}$ in $2 \theta$. Several minor peaks are found at additional locations; however the relatively low intensity indicated low concentration levels. Peaks located at 13.9, 19.7, 24.1, 28.0, 34.6 and $40.1^{\circ}$ in $2 \theta$ were attributed to a $\mathrm{LaAlO}_{3}$ phase. In Figure 19, $\mathrm{SrNi}_{0.4} \mathrm{Al}_{11.6} \mathrm{O}_{19}$ [52] is observed to have major peaks at 11.9, 19.0, 20.1, 21.3, 22.0, 23.2, 24.1, 25.1, 26.4, 33.9, $34.8,38.6,40.9$ and $43.9^{\circ}$ in $2 \theta$. Similarly, in Figure $20, \mathrm{BaNi}_{0.4} \mathrm{Al}_{11.6} \mathrm{O}_{18.8}$ [75] peaks were detected at 11.1, 11.8, 14.3, 18.9, 19.6, 21.1, 22.9, 24.8, 26.0, 33.5, 34.0, 34.4, 38.3, 39.9 and $43.5^{\circ}$ in $2 \theta$.

Cell refinement of the Ni-modified hexaaluminate samples composed of different cations was performed in Jade, with $\mathrm{LaAl}_{11} \mathrm{O}_{18}$ used as the baseline pattern for $\mathrm{La}$, $\mathrm{SrAl}_{12} \mathrm{O}_{19}$ used for $\mathrm{Sr}$, and $\mathrm{Ba}_{0.75} \mathrm{Al}_{11} \mathrm{O}_{17.75}$ used for $\mathrm{Ba}$. As long as the sample pattern and baseline pattern shared the same symmetry and space group of $\mathrm{P}_{3} / m m c$, the refinement results were identical and no error terms were introduced. In the $\mathrm{P}_{3} / \mathrm{mmc}$ space group, the $a$ and $b$ parameters are identical to each other and have a $120^{\circ}$ angle in 
relation to each other. The $c$ parameter is arranged with an angle $90^{\circ}$ to the direction of both $a$ and $b$.

The crystal lattice parameters that were calculated from the cell refinement of fresh, unreacted samples are presented in Table 4.

Table 4: Crystal Lattice Parameters of Fresh Ni-Substituted La, Sr and Ba Hexaaluminates

\begin{tabular}{|c|c|c|c|}
\hline Sample Name & $\boldsymbol{a , b}(\boldsymbol{\AA})$ & $\boldsymbol{c}(\boldsymbol{\AA})$ & Volume $\left(\boldsymbol{\AA}^{\mathbf{3}}\right)$ \\
{$[$ ID\#] } & & & \\
\hline $\mathrm{LaNi}_{0.4} \mathrm{Al}_{11.6} \mathrm{O}_{19}$ & $5.575 \pm$ & $22.034 \pm$ & $592.98 \pm$ \\
{$[35]$} & 0.014 & 0.009 & 2.095 \\
\hline $\mathrm{SrNi}_{0.4} \mathrm{Al}_{11.6} \mathrm{O}_{19}$ & $5.560 \pm$ & $21.971 \pm$ & $588.13 \pm$ \\
{$[52]$} & 0.021 & 0.007 & 3.160 \\
\hline $\mathrm{BaNi}_{0.4} \mathrm{Al}_{11.6} \mathrm{O}_{18.8}$ & $5.596 \pm$ & $22.684 \pm$ & $615.17 \pm$ \\
{$[75]$} & 0.021 & 0.005 & 3.211 \\
\hline
\end{tabular}

The data obtained from the cell refinements in Table 4 are comparable to the ICDD database values for the baseline patterns presented in Table 3. There are a few extra peaks in the spectra of the diffraction patterns are attributed to the presence of an impurity, as in the case of $\mathrm{LaNi}_{0.4} \mathrm{Al}_{11.6} \mathrm{O}_{19}$ [35].

Cell refinement of the fresh $\mathrm{Ba}$ hexaaluminate samples with varying $\mathrm{Ni}$ substitution was also performed via Jade with $\mathrm{Ba}_{0.75} \mathrm{Al}_{11} \mathrm{O}_{17.25}$ used as the baseline pattern. Other than some minor differences in intensity, when compared to Figure 20, there are not any significant differences observed in the X-ray patterns over the remaining $\mathrm{Ba}$ series of catalysts. The crystal lattice parameters that were calculated from the cell refinement are presented in Table 5. 
Table 5: Crystal Lattice Parameters of Fresh Ni-substituted Ba Hexaaluminates

\begin{tabular}{|c|c|c|c|}
\hline Sample Name & $\boldsymbol{a , b}(\boldsymbol{\AA})$ & $\boldsymbol{c}(\boldsymbol{\AA})$ & Volume $\left(\boldsymbol{\AA}^{\mathbf{3}}\right)$ \\
{$[$ ID\#] } & & & \\
\hline $\mathrm{BaAl}_{12} \mathrm{O}_{19}$ & $5.583 \pm$ & $22.720 \pm$ & $613.28 \pm$ \\
{$[38 \mathrm{C}]$} & 0.020 & 0.004 & 3.052 \\
\hline $\mathrm{BaNi}_{0.2} \mathrm{Al}_{11.8} \mathrm{O}_{18.9}$ & $5.588 \pm$ & $22.689 \pm$ & $613.50 \pm$ \\
{$[115 \mathrm{~B}]$} & 0.020 & 0.004 & 3.116 \\
\hline $\mathrm{BaNi}_{0.4} \mathrm{Al}_{11.6} \mathrm{O}_{18.8}$ & $5.596 \pm$ & $22.683 \pm$ & $615.06 \pm$ \\
{$[116 \mathrm{~B}]$} & 0.021 & 0.004 & 3.194 \\
\hline $\mathrm{BaNi}_{0.6} \mathrm{Al}_{11.4} \mathrm{O}_{18.7}$ & $5.603 \pm$ & $22.668 \pm$ & $616.27 \pm$ \\
{$[117 \mathrm{~B}]$} & 0.022 & 0.005 & 3.441 \\
\hline $\mathrm{BaNi}_{0.8} \mathrm{Al} l_{11.2} \mathrm{O}_{18.6}$ & $5.608 \pm$ & $22.643 \pm$ & $616.75 \pm$ \\
{$[118 \mathrm{~B}]$} & 0.010 & 0.003 & 61.597 \\
\hline $\mathrm{BaNiAl}_{11} \mathrm{O}_{18.5}$ & $5.610 \pm$ & $22.641 \pm$ & 1.525 \\
\hline$[119 \mathrm{~B}]$ & 0.010 & 0.004 & \\
\hline
\end{tabular}

Due to the values of the parameters being so close to each other, the cell refinement results will be compared graphically. The $a$ and $b$ parameters are further illustrated as Figure 21 , the $c$ parameters of the barium series are shown as Figure 22 and the overall cell volumes of the $\mathrm{Ba}$ hexaaluminates are illustrated as Figure 23.

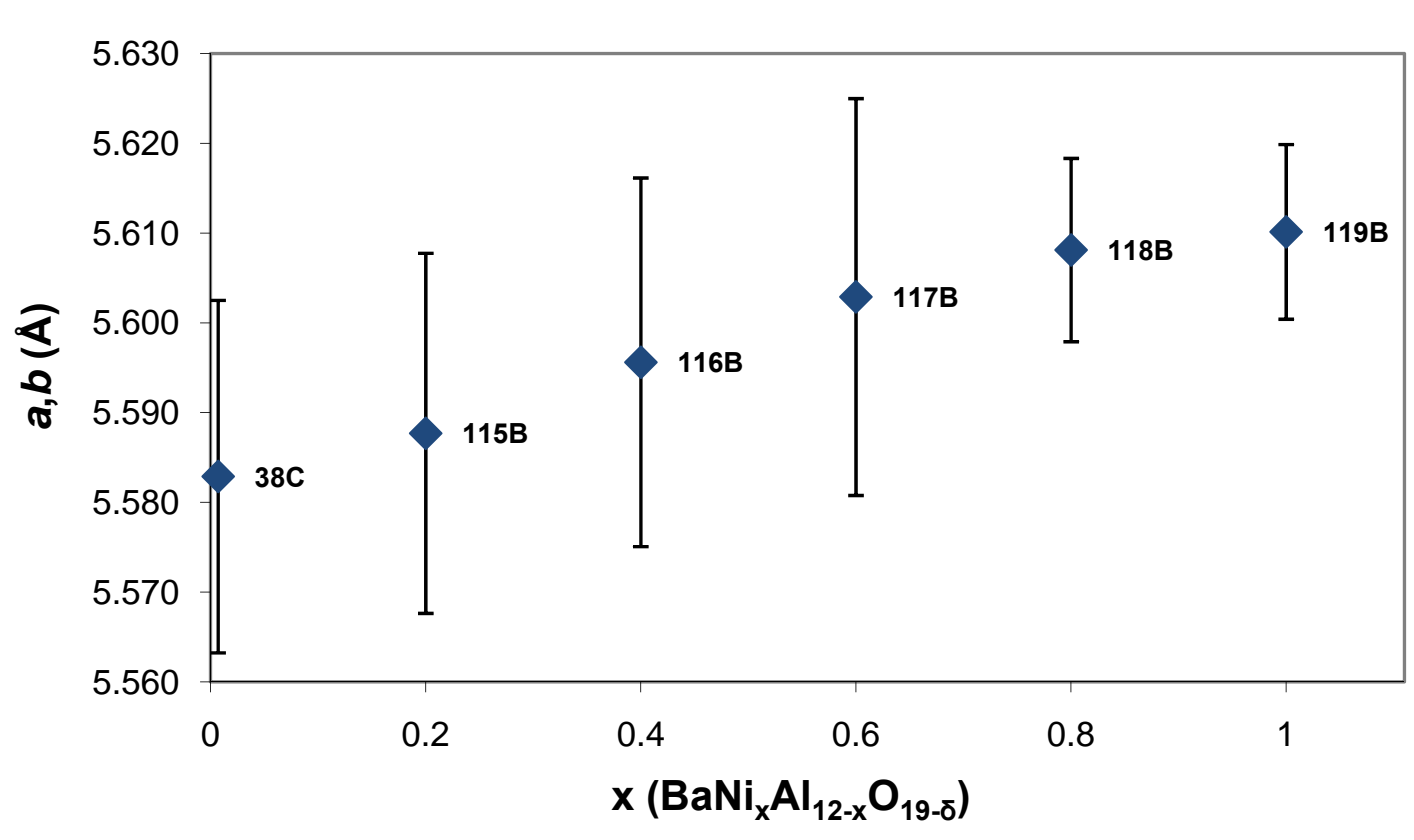

Figure 22: $a$ and $b$ lattice parameters of fresh Ba Ni-substituted hexaaluminates 


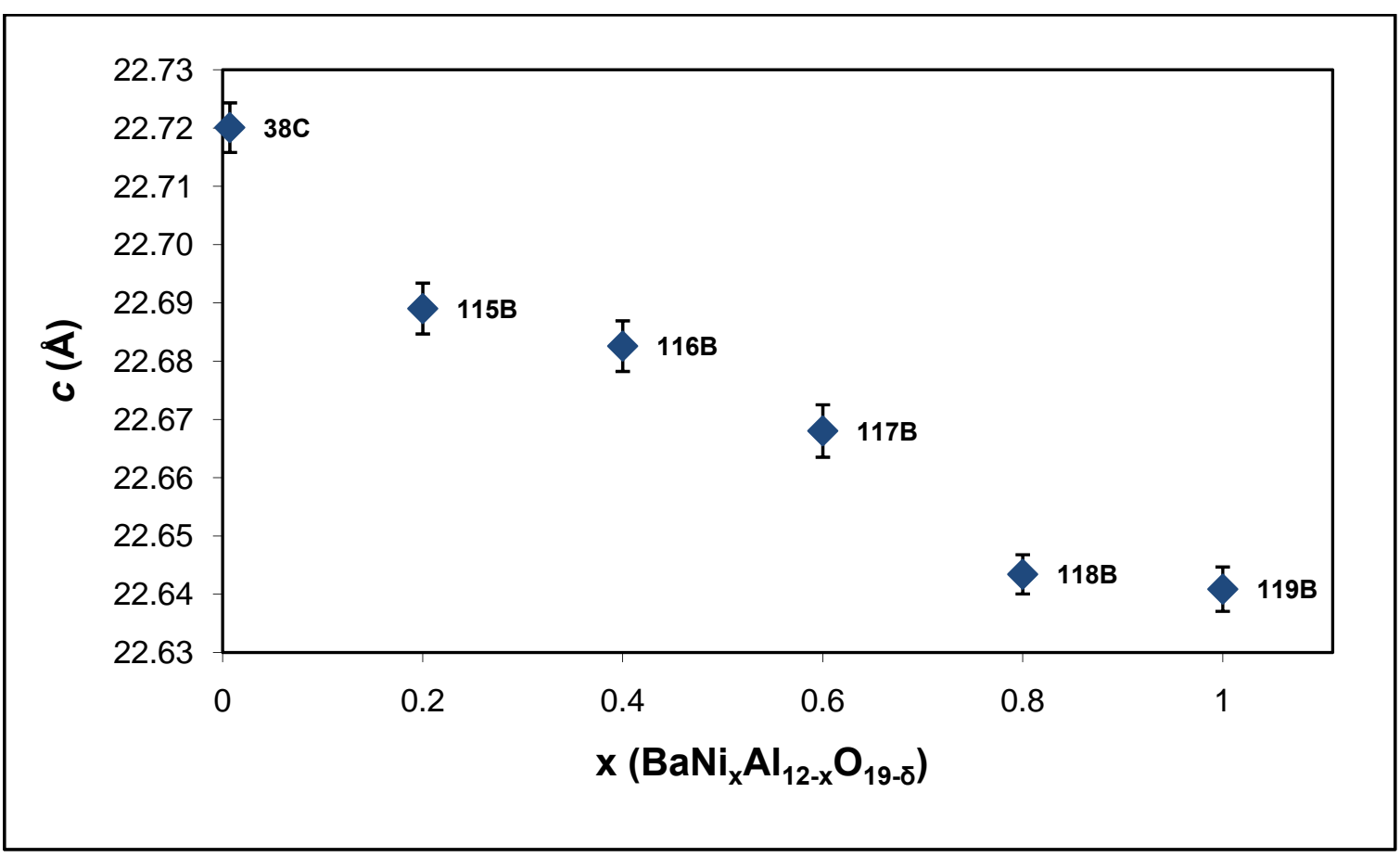

Figure 23: $c$ lattice parameters of fresh Ba Ni-substituted hexaaluminates

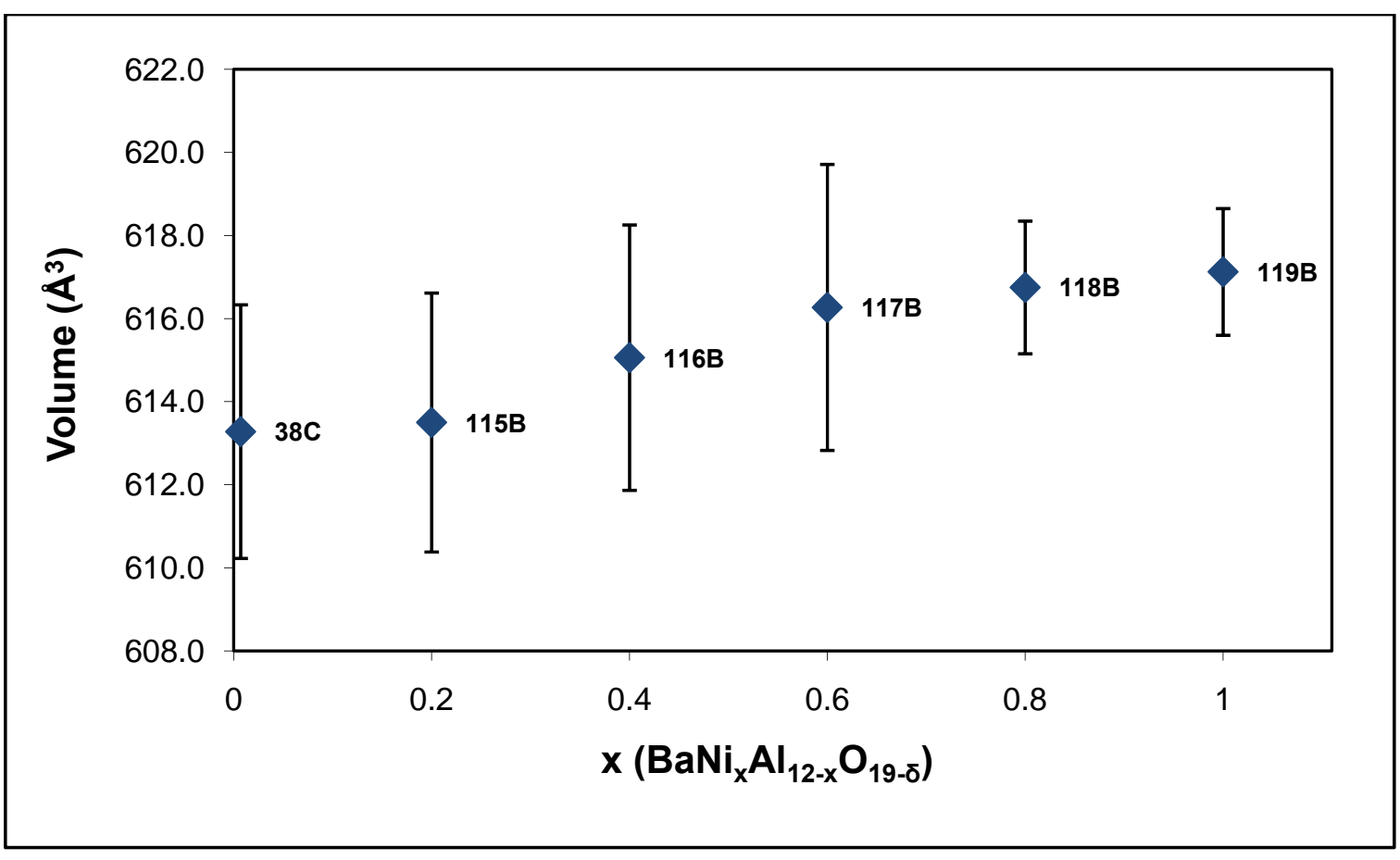

Figure 24: Cell volumes of fresh Ni-substituted Ba hexaaluminates 
The figures show that the $a$ and $b$ dimensions expand and the $c$ dimension contracts with higher levels of Ni substitution. This observation is similar to the findings by Machida et al. $(11 ; 19)$ of suppressed growth along the $c$ axis in comparison to the $a$ and $b$ axes. The variations in Figures 21 and 22 result in an overall increase in the cell volume in Figure 23, proportional to the Ni level in the lattice. From the change in unitcell dimensions with $\mathrm{Ni}$ substitution, there is a clear indication that $\mathrm{Ni}$ is being exchanged into the fresh hexaaluminate lattice.

Unit-cell refinement was also performed on the used Ni-substituted $\mathrm{Ba}$ hexaaluminate series of catalysts that were used for TPO of the POx of $\mathrm{CH}_{4}$ studies at NETL (18). Samples were recovered from the catalyst bed upon completion of experiments. As noted earlier in Section 2.1, the leading edge of the catalyst bed had blue catalyst particles, whereas the particles further into the reactor had turned from blue to gray. The gray color is attributed to reduction of $\mathrm{Ni}^{+2}$ ions in the hexaaluminate lattice to $\mathrm{Ni}^{0}$ metal on the edge of the unit cell. Table 6 illustrates the crystal lattice parameters that were calculated from the unit-cell refinement.

Table 6: Crystal Lattice Parameters of Gray Ni-substituted Ba Hexaaluminates

\begin{tabular}{|c|c|c|c|}
\hline Sample Name & $\boldsymbol{a , b}(\boldsymbol{\AA})$ & $\boldsymbol{c}(\boldsymbol{\AA})$ & Volume $\left(\mathbf{\AA}^{\mathbf{3}}\right)$ \\
{$[\mathbf{I D \#}]$} & & & \\
\hline $\mathrm{BaNi}_{0.2} \mathrm{Al}_{11.8} \mathrm{O}_{18.9}$ & $5.584 \pm$ & $22.677 \pm$ & $612.47 \pm$ \\
{$[115 \mathrm{~B}$-gray] } & 0.020 & 0.004 & 3.038 \\
\hline $\mathrm{BaNi}_{0.4} \mathrm{Al}_{11.6} \mathrm{O}_{18.8}$ & $5.588 \pm$ & $22.652 \pm$ & $612.48 \pm$ \\
{$[116 \mathrm{~B}$-gray] } & 0.014 & 0.005 & 2.124 \\
\hline $\mathrm{BaNi}_{0.6} \mathrm{Al}_{11.4} \mathrm{O}_{18.7}$ & $5.591 \pm$ & $22.632 \pm$ & $612.62 \pm$ \\
{$[117 \mathrm{~B}$-gray] } & 0.021 & 0.004 & 3.185 \\
\hline $\mathrm{BaNi}_{0.8} \mathrm{Al}_{11.2} \mathrm{O}_{18.6}$ & $5.587 \pm$ & $22.611 \pm$ & 3.442 \\
{$[118 \mathrm{~B}$-gray $]$} & 0.022 & 0.004 & $612.75 \pm$ \\
\hline $\mathrm{BaNiAl}_{11} \mathrm{O}_{18.5}$ & $5.592 \pm$ & $22.625 \pm$ & 3.911 \\
\hline $119 \mathrm{~B}$-gray $]$ & 0.025 & 0.005 & \\
\hline
\end{tabular}

The $a$ and $b$ parameters of the used Ni-substituted Ba hexaaluminates are illustrated as Figure 24 , the $c$ parameters of the series are shown as Figure 25, and the overall cell volumes are illustrated as Figure 26. 


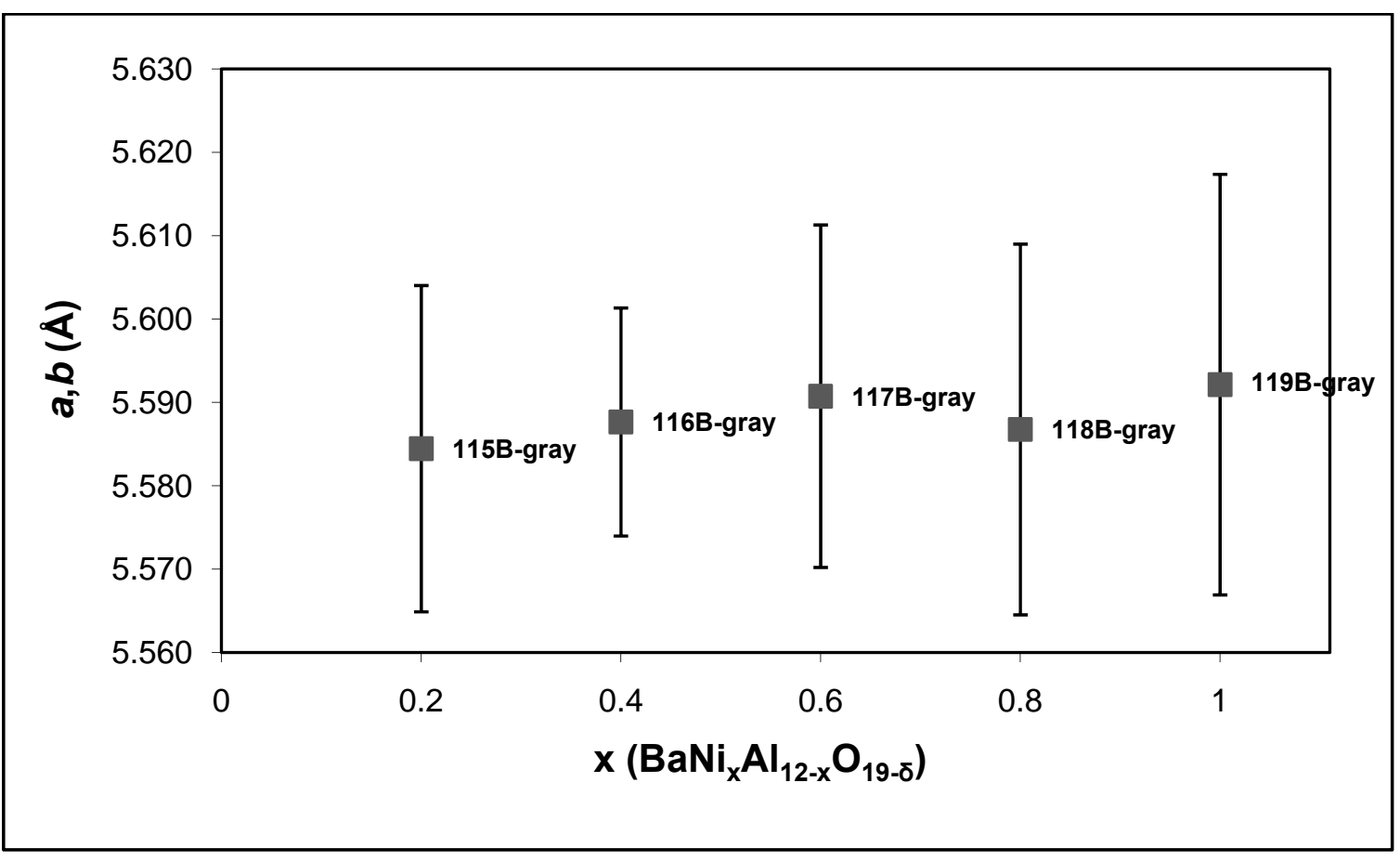

Figure 25: $a$ and $b$ lattice parameters of used gray Ni-substituted Ba hexaaluminates

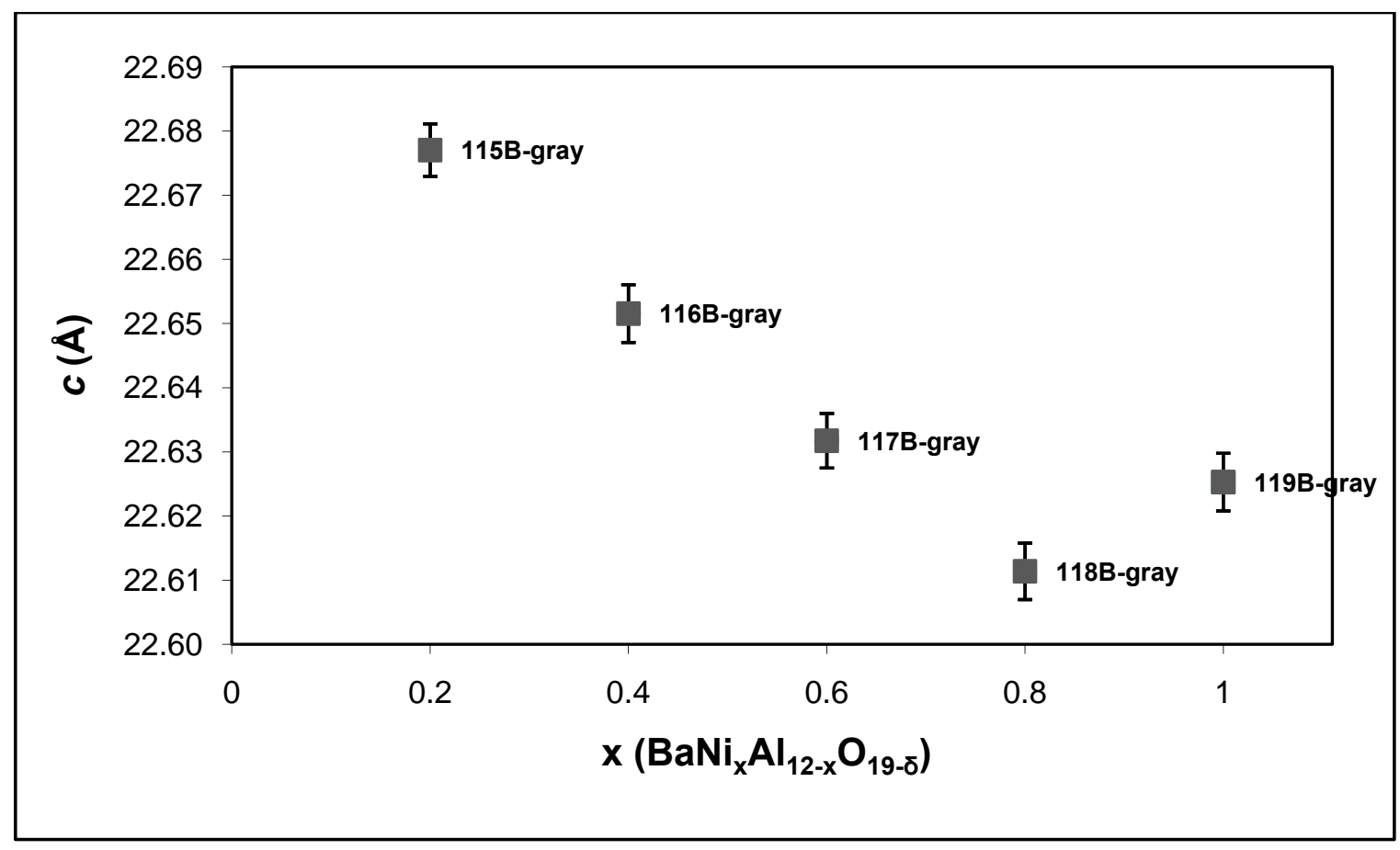

Figure 26: $c$ lattice parameters of used gray Ni-substituted Ba hexaaluminates 


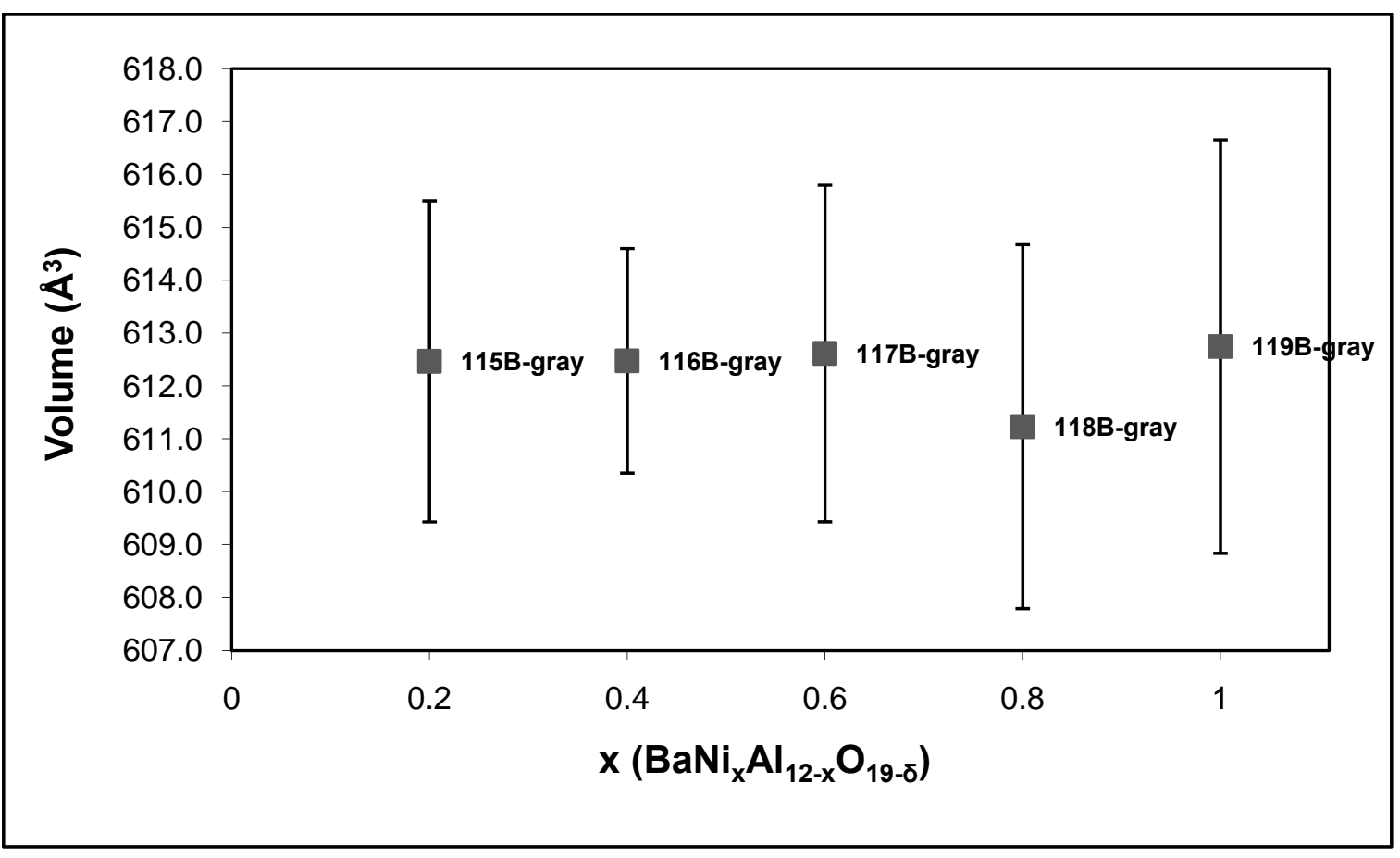

Figure 27: Cell volumes of used gray Ni-substituted Ba hexaaluminates

The cell refinement data of the used Ni-substituted $\mathrm{Ba}$ hexaaluminate catalysts that were involved with TPO of the $\mathrm{POx}$ of $\mathrm{CH}_{4}$ follows similar trends to that of the fresh catalyst samples. The data indicate that $\mathrm{Ni}$ is still present within the hexaaluminate lattice. The figures indicate that the $c$ parameter contracts with higher levels of $\mathrm{Ni}$ substitution. However, the $a$ and $b$ dimensions and the overall cell volume were not found to be proportional to the $\mathrm{Ni}$ level in the lattice. The data indicates that the $\mathrm{Ni}^{+2}$ ions have been reduced to $\mathrm{Ni}^{0}$ and relocated from the unit cell.

For analysis, the data of the fresh and used Ni-substituted Ba hexaaluminates are compared graphically. Figure 27 compiles the $a$ and $b$ parameters of both of the unreacted and reacted samples. As can be seen in Figure 27, there is a smaller variation in the $a$ and $b$ parameters of the used samples than the fresh catalysts. When going from lower to higher Ni substitution the $a$ and $b$ parameters of the fresh samples have a positive slope but there is essentially no slope between the used samples. This is attributed to a portion of the $\mathrm{Ni}^{+2}$ ions moving from within the hexaaluminate lattice to the surface during the TPR procedure. This results in the $a$ and $b$ parameters of the hexaaluminate cell contracting with the movement of $\mathrm{Ni}$ and the structural measurements of the hexaaluminate series becoming more similar to each other. 


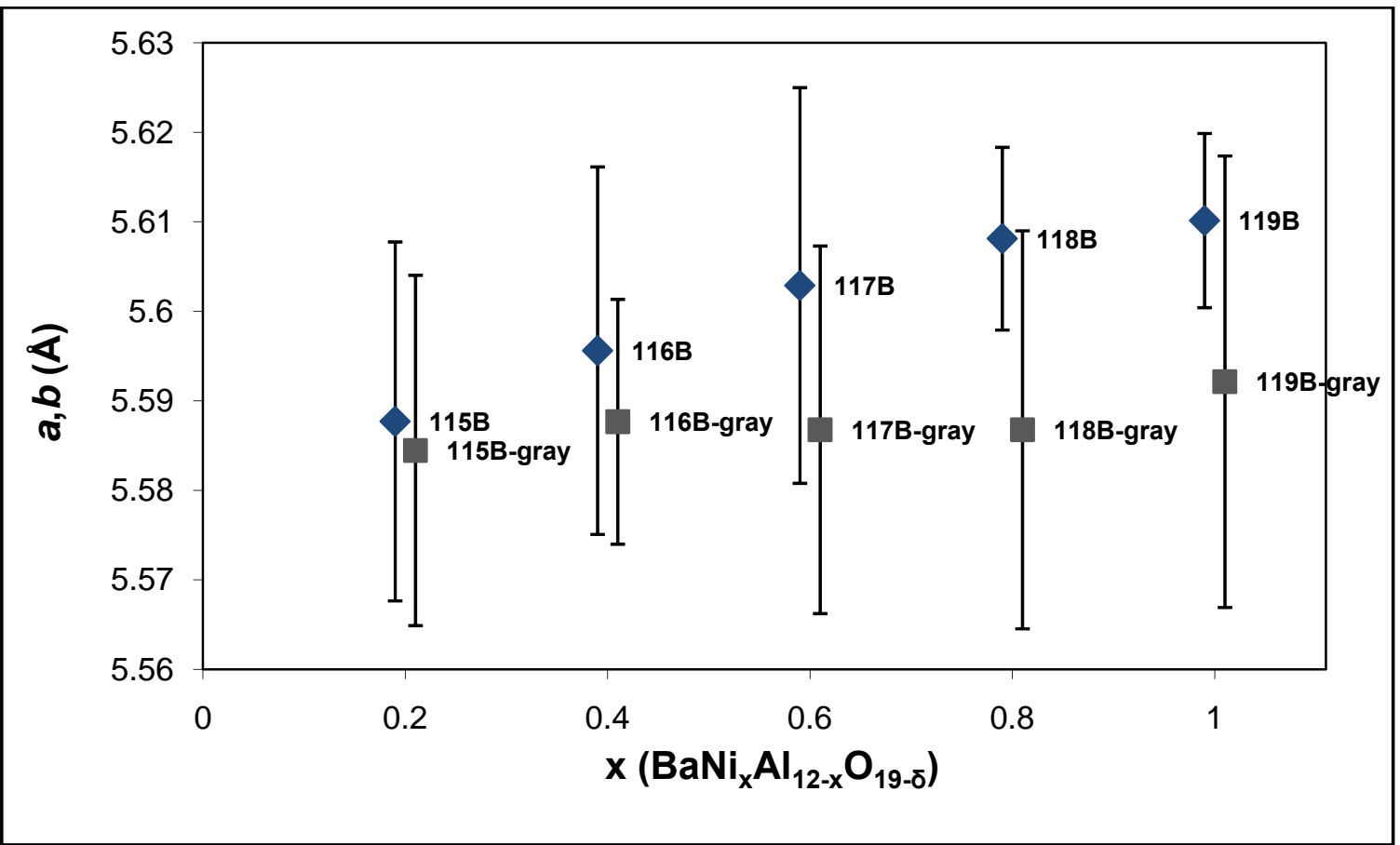

Figure 28: Compilation of $a$ and $b$ unit-cell refinement data of both fresh and used samples

Figure 28 is a compilation of the $c$ parameters of the catalysts before and after reaction.

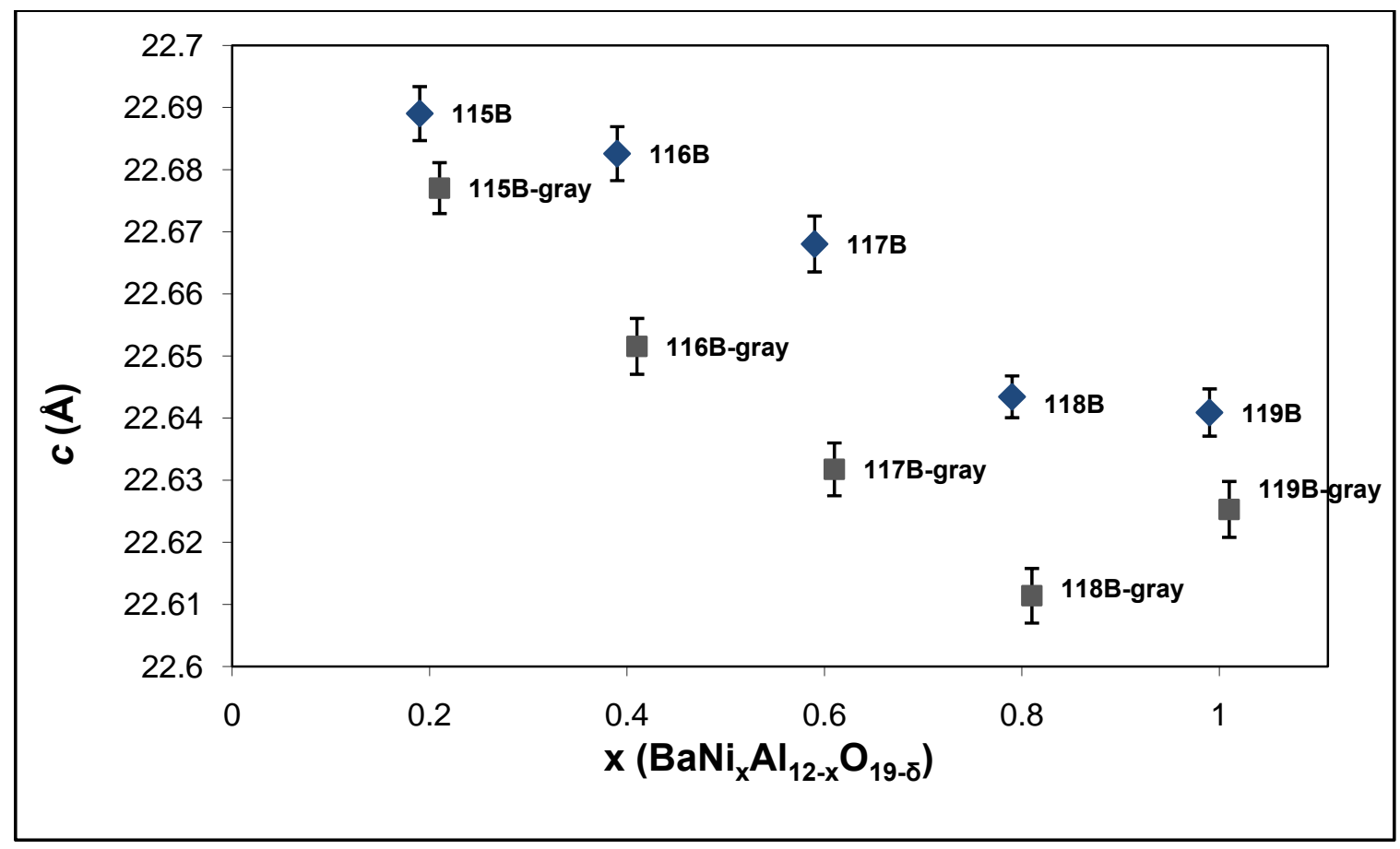

Figure 29: Compilation of $c$ unit-cell refinement data of both fresh and used samples 
Although the $a, b$ parameters of the Ni-substituted $\mathrm{Ba}$ hexaaluminates contract after the TPO reaction of the POx of $\mathrm{CH}_{4}$, the $c$ parameters exhibit little to no contraction and are almost unchanged by reaction. The gray samples have higher values of the $c$ parameters than the fresh samples which could be influenced by carbon deposition.

Figure 29 is the accumulated volumetric data of the unit cell calculations.

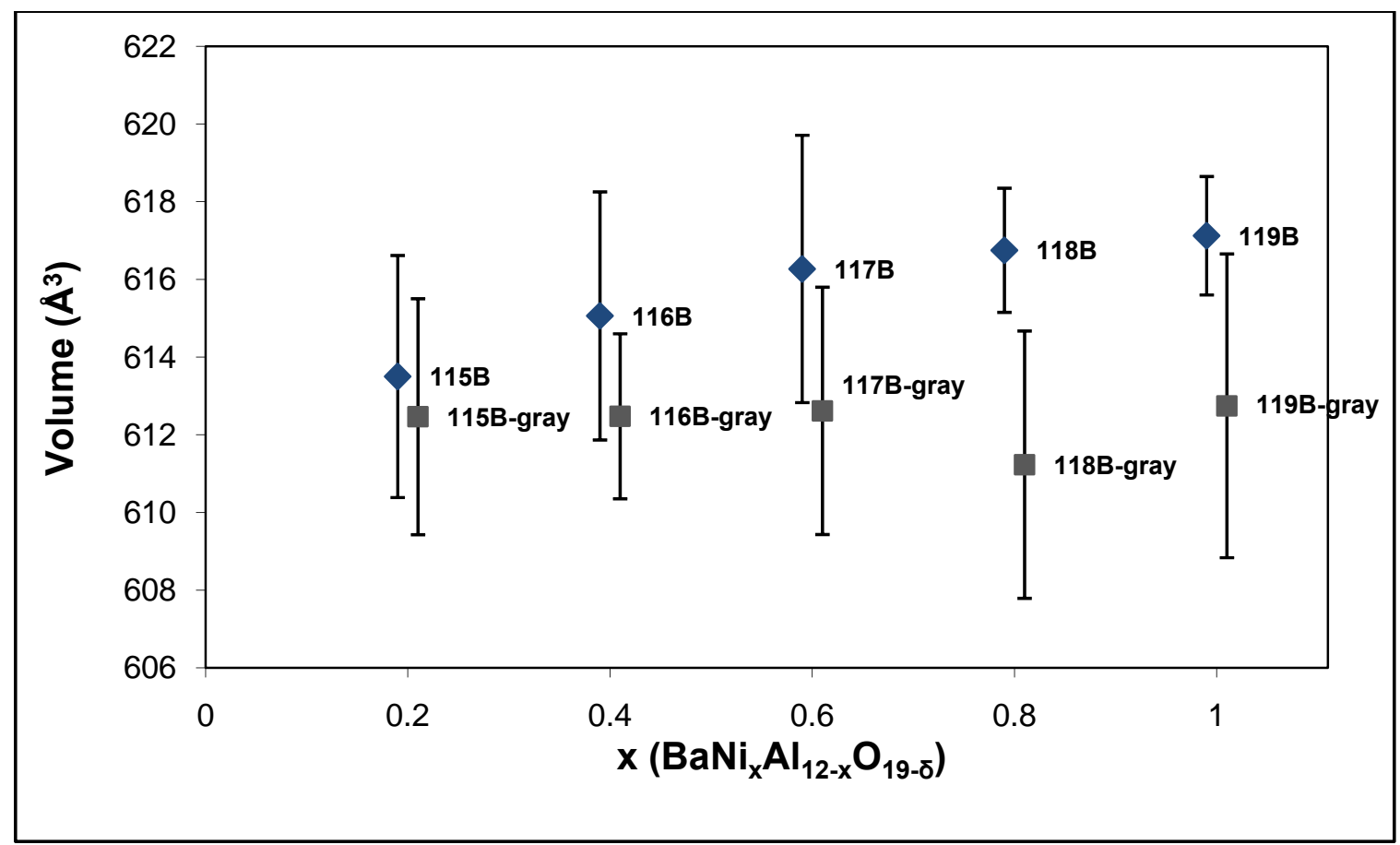

Figure 30: Compilation of unit-cell refinement of cell volume data of both fresh and used samples

Similarly to the $a$ and $b$ parameters of the catalysts, the unit-cell volume of the unreacted series has more variation than the catalysts used for $\mathrm{CH}_{4} \mathrm{POx}$. In going from lower to higher Ni-substituted samples, the unreacted series has a positive slope and the reacted catalysts series has a zero slope indicating a loss of Ni from the unit-cell lattices. While the overall cell volumes of the fresh catalysts increased with Ni substitution, the post-reaction volumes of the unit-cells showed little to no difference between higher and lower Ni substitution.

From the unit-cell refinement study, it is concluded that the addition of $\mathrm{Ni}$ is substituted into the hexaaluminate lattice and increases the $a$ and $b$ parameters as well as the overall cell volume of the samples. The $c$ parameter decreases with increased $\mathrm{Ni}$ substitution. Upon TPR via $\mathrm{H}_{2}$ and TPO reaction studies of $\mathrm{CH}_{4} \mathrm{POx}, \mathrm{Ni}^{+2}$ ions are 
reduced to $\mathrm{Ni}^{0}$ metal and relocate from the lattice via the $a$ and $b$ directions and are heavily involved with catalytic activity of the catalyst. The $c$ parameters are mostly unchanged from the values of those of the fresh samples indicating the $c$ dimension is unaffected by the POx reaction. The overall cell volumes of the reacted, higher Nisubstituted Ba hexaaluminates approach the values of the lower Ni-composition catalysts.

\subsubsection{In situ TPR-XRD}

Temperature-programmed reduction with simultaneous X-ray diffraction was performed as described in Section 3.2.1 to determine the speciation between nickel ions in the hexaaluminate lattice from nickel metal on the catalyst surface. Each sample was heated while flushed with $\mathrm{H}_{2}$ gas. X-ray diffraction patterns were simultaneously measured at regular time intervals to determine any changes in the crystal structure as a function of time and temperature. If peaks appear at the values of $\mathrm{Ni}^{0}$ metal, then $\mathrm{Ni}$ comes out of the hexaaluminate structure when reduced, whereas no change in cell structure demonstrates that no separation took place. Additionally, TPO of $\mathrm{CH}_{4}$ provided information on the oxidation state before and after reaction.

The locations for nickel metal ICDD [00-004-0850] peaks at $0.9225 \AA$ wavelength were tabulated from the ICDD database and are presented in Table 7:

Table 7: Positions of $\mathrm{Ni}^{0}$ Metal Peaks at Wavelength of $0.9225 \AA$

\begin{tabular}{|c|c|c|}
\hline Degrees in 20 & Relative Intensity & Lattice Plane (h,k,l) \\
\hline 26.214 & $100 \%$ & $(1,1,1)$ \\
\hline 30.351 & $42 \%$ & $(2,0,0)$ \\
\hline 43.454 & $21 \%$ & $(2,2,0)$ \\
\hline
\end{tabular}

Since $\mathrm{Ni}^{0}$ metal peaks do not occur beyond $43.5^{\circ}$ in $2 \theta$, the region of interest for this study is in the range of $25-45^{\circ}$ in $2 \theta$. It is expected that, while the sample is heated and flushed with the $5 \% \mathrm{H}_{2}$ gas mixture, the $\mathrm{Ni}^{+2}$ ion will be reduced to $\mathrm{Ni}^{0}$. Consequently, the $\mathrm{Ni}^{0}$ metal will form on the surface of the active catalyst, distinguishing the surface species from the ions in the hexaaluminate lattice and shifting the lattice structure. Unless the peaks are masked by the hexaaluminate structure, the diffraction lines for metallic $\mathrm{Ni}^{0}$ appear at the above mentioned locations in degrees $2 \theta$, providing evidence that $\mathrm{Ni}^{+2}$ reduction has occurred. 
Over the range of $25^{\circ} \mathrm{C}$ to $925^{\circ} \mathrm{C}$, lines of the TPR-XRD figures indicate readings taken at $50^{\circ} \mathrm{C}$ intervals. Upon reaching $925^{\circ} \mathrm{C}$, the temperature is held for $30 \mathrm{~min}$ and scans were taken every 5 minutes. In these TPR-XRD figures (Figures 30-38), the $x$ axis is the diffraction angle in units of degrees in $2 \theta$, the $y$ axis is the scan number (not shown) and the $z$ axis is the intensity in arbitrary units (not shown). The figures were taken at a 40-degree viewing angle in the $y$ direction and an angle of zero degrees in each of the $x$ and $z$ axes. It is important to note that the peaks shift to the left as the temperature is increased due to thermal expansion, and at the upper portion of the figure, the peaks will appear to form at lower angles at $925^{\circ} \mathrm{C}$ than they would at lower temperatures. The arrows in the TPR-XRD figures mark the areas where peaks would be expected to appear near $26.2^{\circ}, 30.3^{\circ}$ and $43.5^{\circ}$, indicating that $\mathrm{Ni}^{0}$ metal particles relocated to the surfaces of the hexaaluminates at elevated temperatures.

The first set of samples to be analyzed was the series varying the mirror cation while holding the nickel substitution level constant at $\mathrm{x}=0.4$. Figure 30 illustrates the TPR-XRD measurement of $\mathrm{LaNi}_{0.4} \mathrm{Al}_{11.6} \mathrm{O}_{19}$ [35] from $25-45^{\circ}$ in $2 \theta$.

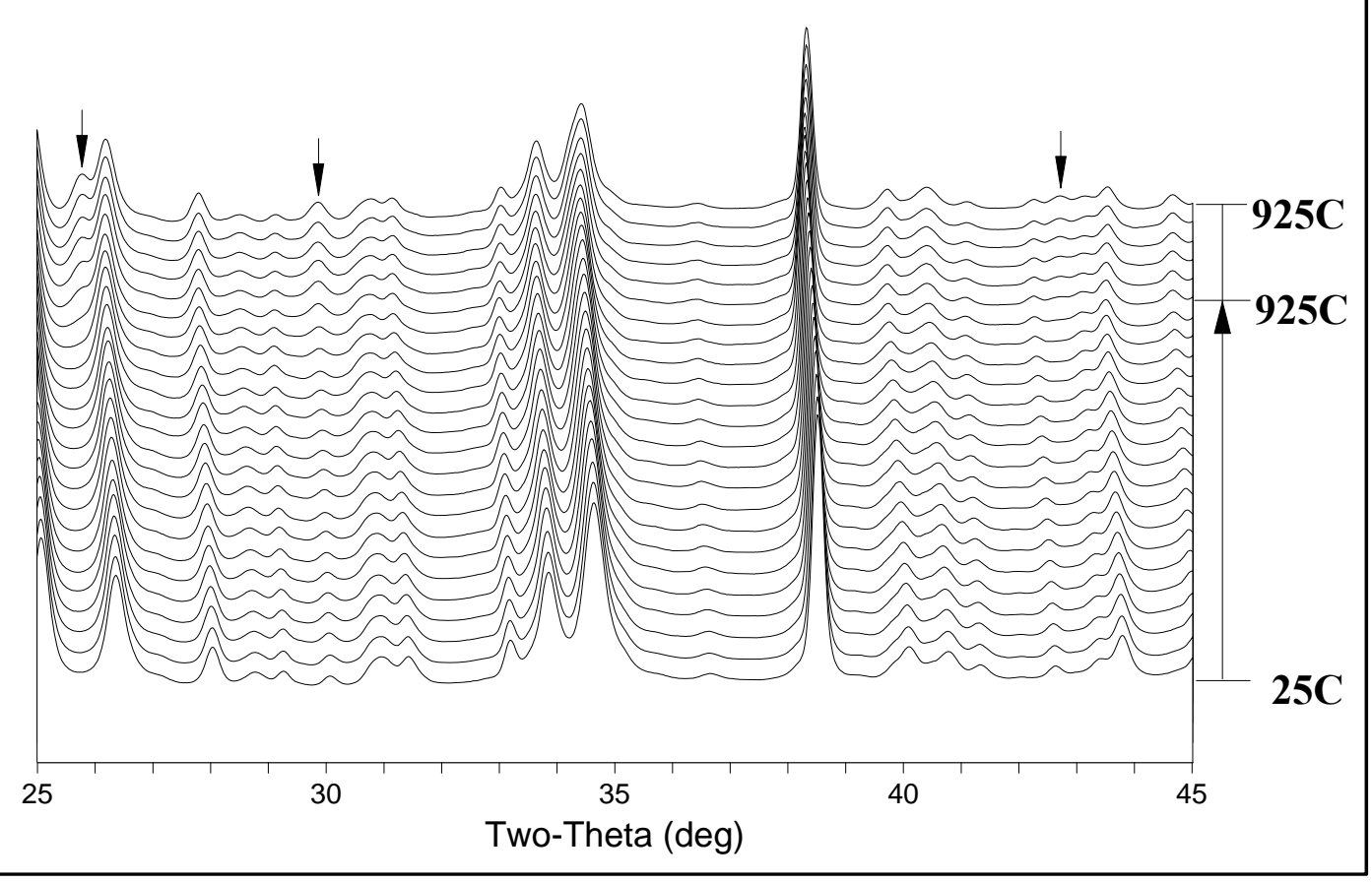

Figure 31: TPR-XRD of $\mathrm{LaNi}_{0.4} \mathrm{Al}_{11.6} \mathrm{O}_{19}[35]$ from $25-45^{\circ}$ in $2 \theta$ 
Figure 31 takes a closer viewpoint of the spectra for $\mathrm{LaNi}_{0.4} \mathrm{Al}_{11.6} \mathrm{O}_{19}$ [35] in the range of $25-35^{\circ}$ in $2 \theta$, where the strongest peak for metallic $\mathrm{Ni}^{0}$ is expected to appear.

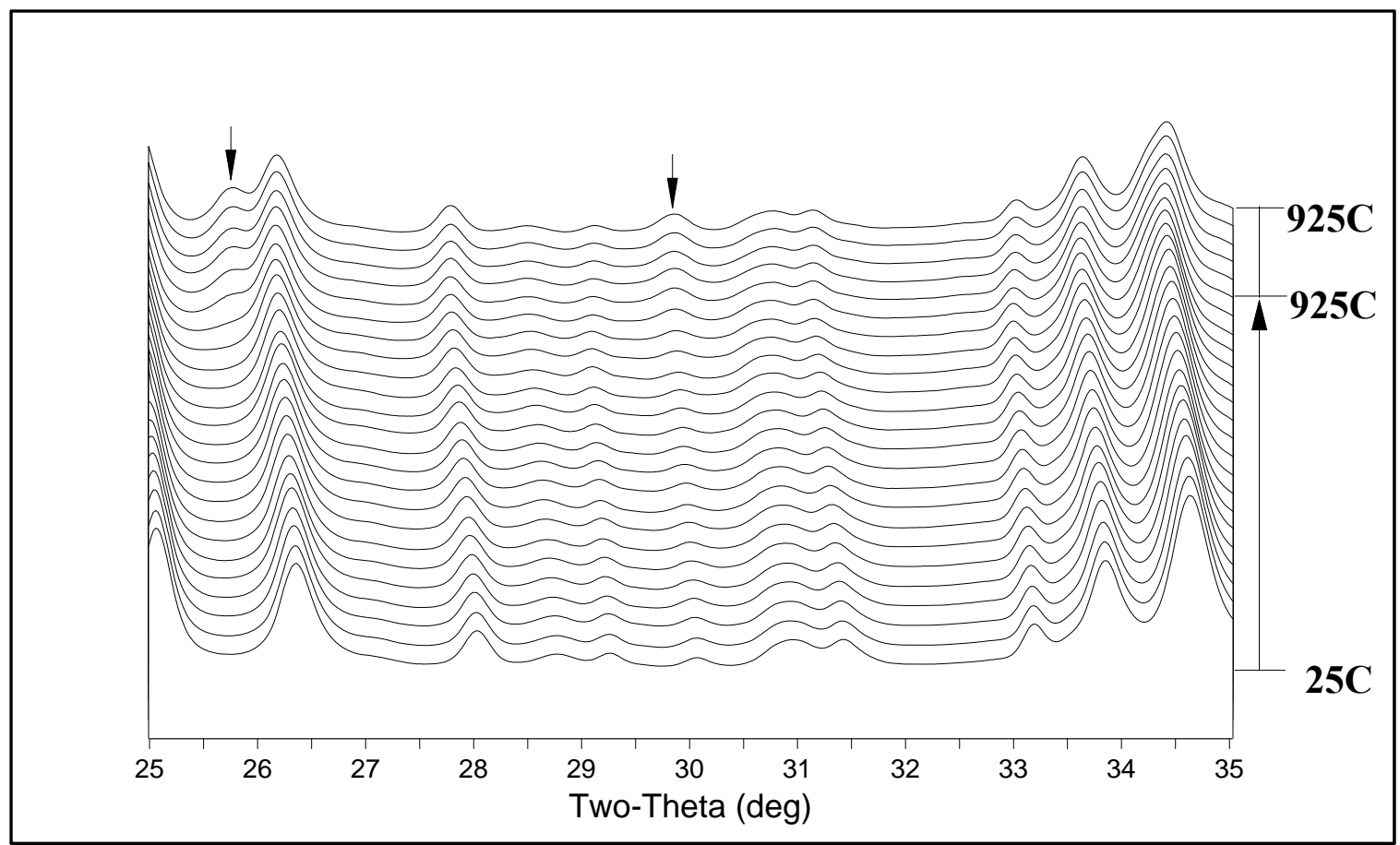

Figure 32: Detail of TPR-XRD of $\mathrm{LaNi}_{0.4} \mathrm{Al}_{11.6} \mathrm{O}_{19}[35]$ from $25-35^{\circ}$ in $2 \theta$

Again, the formation of a peak near $26.2^{\circ}$ in $2 \theta$ is clearly distinguishable. The $\mathrm{Ni}^{0}$ peak forms around $900^{\circ} \mathrm{C}$ and shifts to the left of the hexaaluminate peak as the temperature increases, until there are two separate peaks. The $\mathrm{Ni}^{0}$ peak appears due to the exchanged $\mathrm{Ni}^{+2}$ in the La hexaaluminate being reduced. With reduction, $\mathrm{Ni}^{+2}$ ions relocate from the hexaaluminate crystal structure to form metallic $\mathrm{Ni}^{0}$. An $\mathrm{O}^{-2}$ or $\mathrm{OH}^{-}$ion also comes out of the hexaaluminate lattice to maintain charge balance. The hexaaluminate diffraction peaks show little change during the TPR-XRD procedure, indicating that the majority of sample activity is due to Ni transition. It is difficult to obtain a clear view of a metallic $\mathrm{Ni}^{0}$ peak at $30.3^{\circ}$ in $2 \theta$ due to an overlap with the hexaaluminate peaks; however, there is a small increase in intensity at this point during the hold period at $925^{\circ} \mathrm{C}$. 
Figure 32 allows a zoomed-in look at the $\mathrm{LaNi}_{0.4} \mathrm{Al}_{11.6} \mathrm{O}_{19}$ [35] peak at $43.5^{\circ}$ in $2 \theta$.

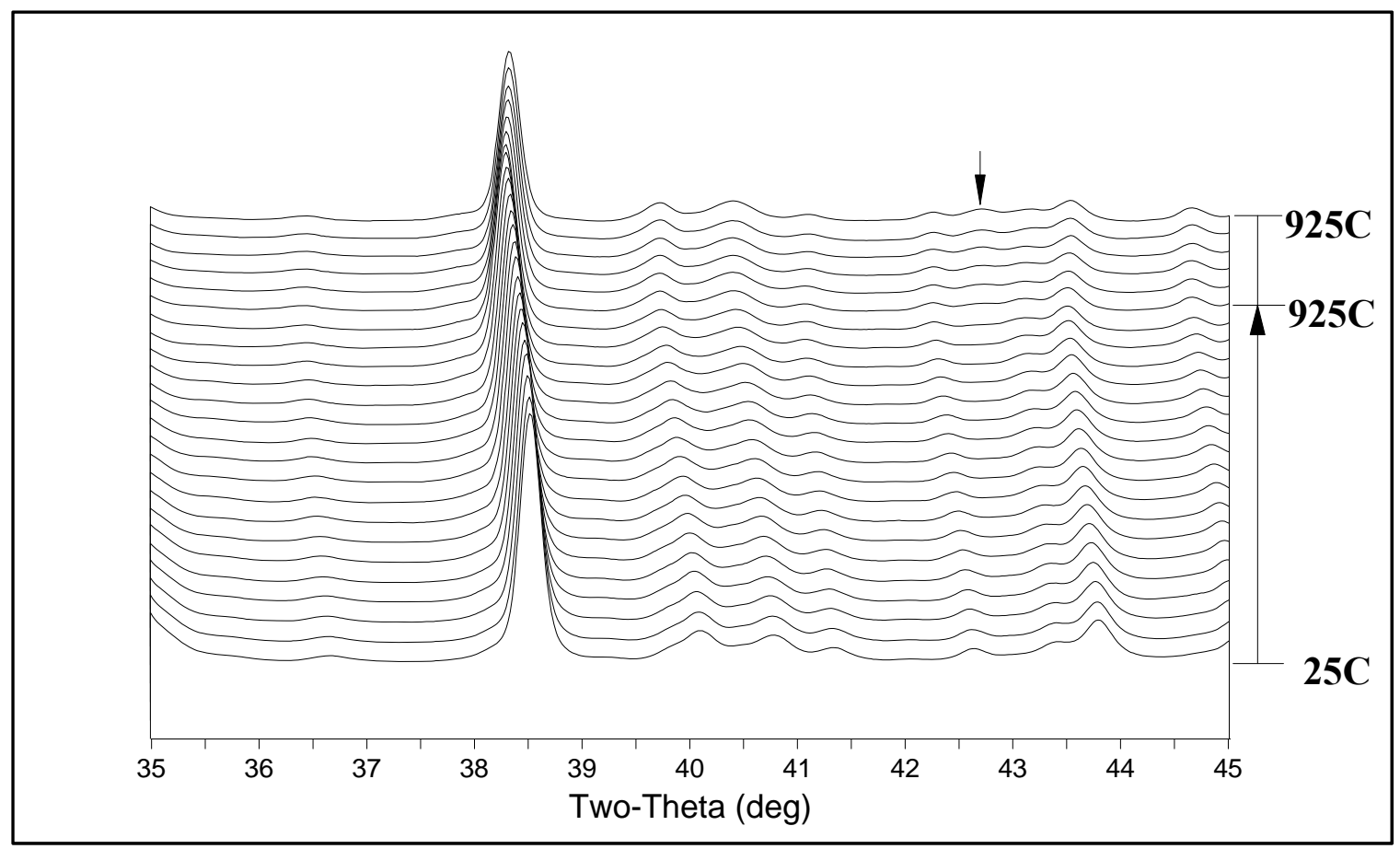

Figure 33: Detail of TPR-XRD of $\mathrm{LaNi}_{0.4} \mathrm{Al}_{11.6} \mathrm{O}_{19}[35]$ from $35-45^{\circ}$ in $2 \theta$

The peak at $43.5^{\circ}$ is very weak in intensity and could easily be overlooked. However, the behavior of the Ni peak at $43.5^{\circ}$ is similar to that of the peak at $26.2^{\circ}$, in that the peak appears around $900^{\circ} \mathrm{C}$ among the hexaaluminate structural peaks. As can be seen from the large hexaaluminate peak at $38.6^{\circ}$, there is a shift toward lower angles as the hexaaluminate structure expands during heating. Once the $\mathrm{Ni}^{+2}$ is reduced at $925^{\circ} \mathrm{C}$, the size of the unit-cell contracts and the hexaaluminate peak reverses direction, shifting toward higher angles as $\mathrm{Ni}^{0}$ metal forms and leaves the cell lattice.

The plot of TPR-XRD data of Ni-substituted $\mathrm{Sr}$ hexaaluminate has similar results. Figure 33 illustrates the TPR-XRD measurement of $\mathrm{SrNi}_{0.4} \mathrm{Al}_{11.6} \mathrm{O}_{19}$ [52] during the entire region of interest of $25-45^{\circ}$ in $2 \theta$. The structure of the $\mathrm{SrNi}_{0.4} \mathrm{Al}_{11.6} \mathrm{O}_{19}$ [52] sample allows $\mathrm{Ni}^{0}$ peaks that appear at all three positions $\left(26.2^{\circ}, 30.3^{\circ}\right.$ and $43.5^{\circ}$ in $\left.2 \theta\right)$ to be viewed. 


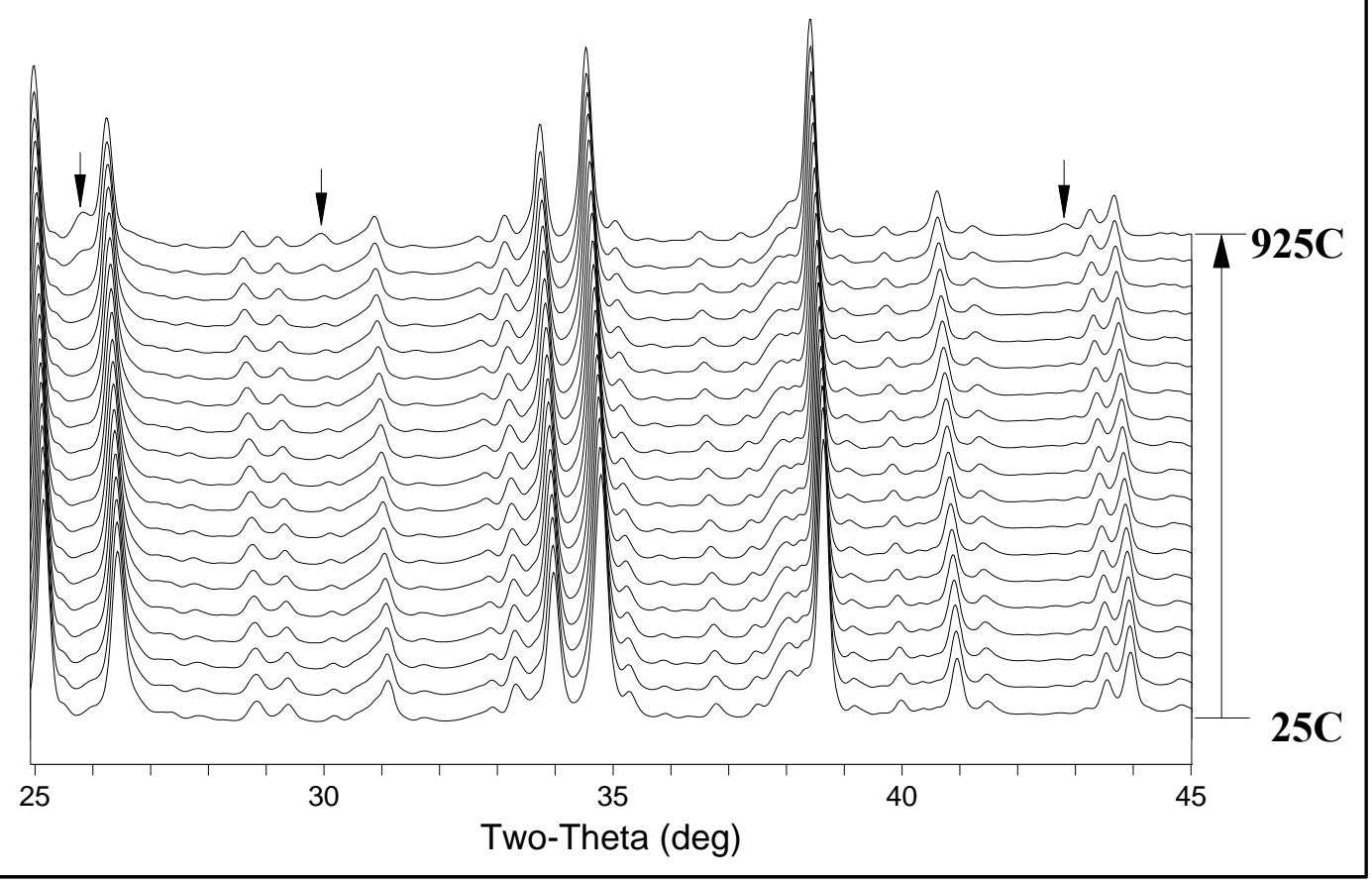

Figure 34: TPR-XRD of $\mathrm{SrNi}_{0.4} \mathrm{Al}_{11.6} \mathrm{O}_{19}[52]$ from $25-45^{\circ}$ in $2 \theta$

Figure 34 allows a closer inspection of the peaks at $26.2^{\circ}$ and $30.3^{\circ}$ in $2 \theta$.

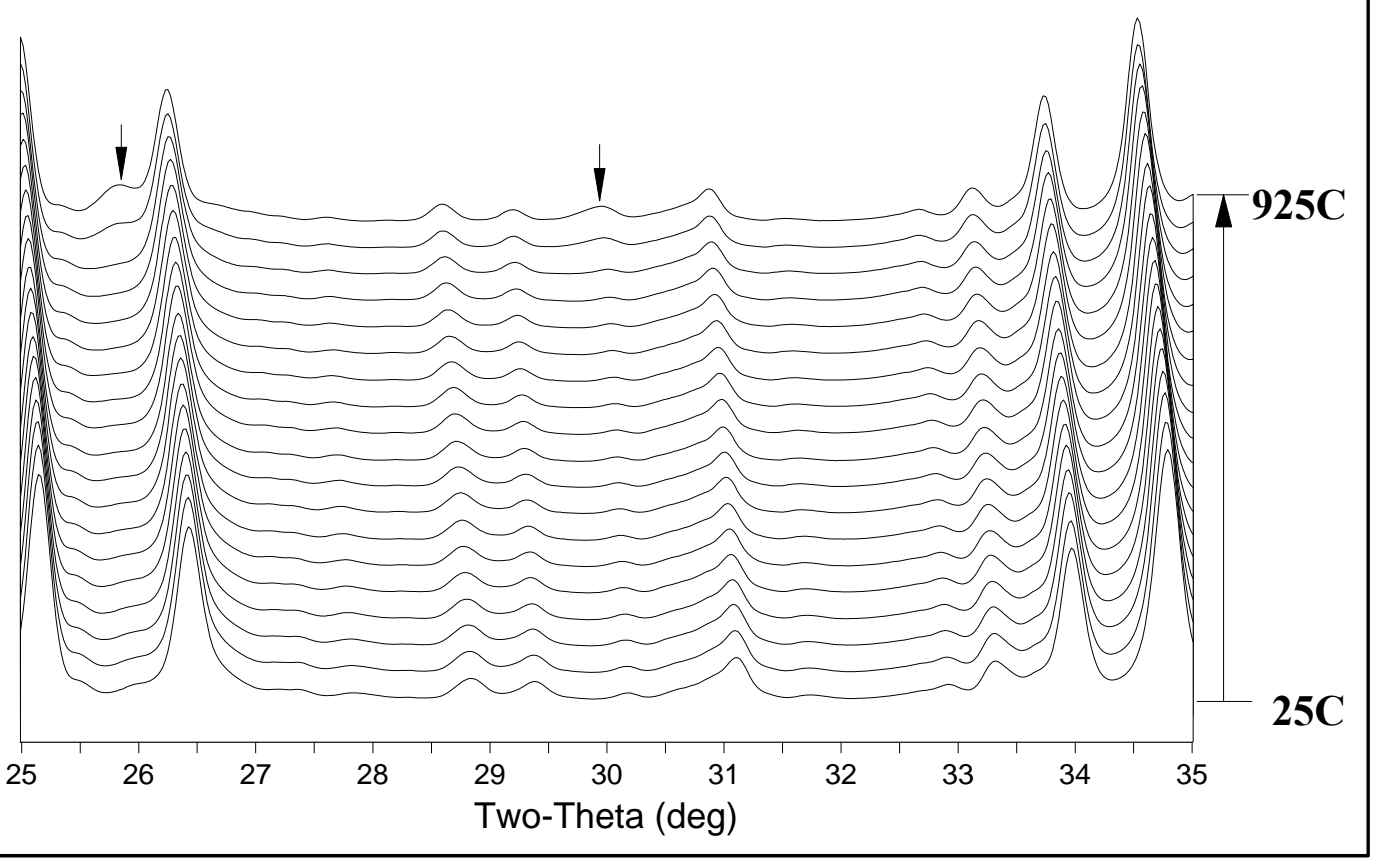

Figure 35: Detail of TPR-XRD of $\mathrm{SrNi}_{0.4} \mathrm{Al}_{11.6} \mathrm{O}_{19}[52]$ from $25-35^{\circ}$ in $2 \theta$ 
It can be seen in Figure 34 that a $\mathrm{Ni}^{0}$ metal peak is formed at $26.2^{\circ}$ and follows similar behavior as the results of the $\mathrm{LaNi}_{0.4} \mathrm{Al}_{11.6} \mathrm{O}_{19}$ [35] sample. There is also a small increase in the peak at $30.3^{\circ}$ that is attributed to the formation of metallic Ni. There is another weak $\mathrm{Ni}^{0}$ peak near $43.5^{\circ}$ in $2 \theta$ that is illustrated more clearly in Figure 35.

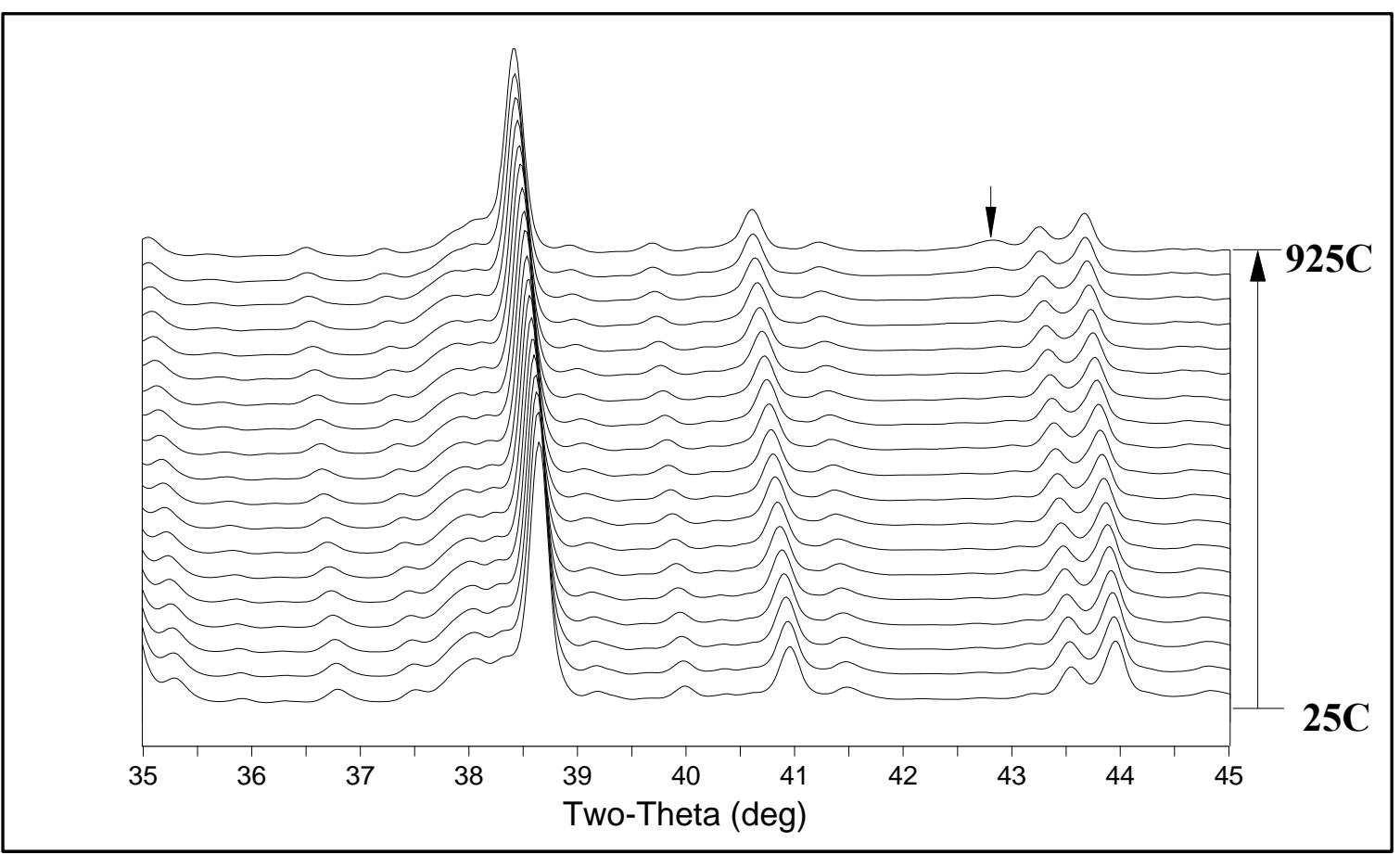

Figure 36: Detail of TPR-XRD of $\mathrm{SrNi}_{0.4} \mathrm{Al}_{11.6} \mathrm{O}_{19}[52]$ from $35-45^{\circ}$ in $2 \theta$

When comparing the peak at $38.6^{\circ}$ on the $\mathrm{SrNi}_{0.4} \mathrm{Al}_{11.6} \mathrm{O}_{19}$ [52] peak on Figure 35 to the $\mathrm{LaNi}_{0.4} \mathrm{Al}_{11.6} \mathrm{O}_{19}$ [35] peak on Figure 32, it can be seen that the peak has not begun to arc to higher angles at $925^{\circ} \mathrm{C}$. This is an indication that the $\mathrm{Ni}^{0}$ peak has just begun to appear and the reaction was ended too soon. It is important to note that the $\mathrm{SrNi}_{0.4} \mathrm{Al}_{11.6} \mathrm{O}_{19}$ [52] sample was run prior to the rest of the samples, and a hold period at $925^{\circ} \mathrm{C}$ was not deemed necessary at that time. After reviewing these data, a hold period of $30 \mathrm{~min}$ was applied to the rest of the samples and this resulted in a more-intense $\mathrm{Ni}^{0}$ peak definition. The low intensity of the $\mathrm{Ni}^{0}$ peak formation during TPR-XRD is credited to incomplete reduction due to slow reaction and diffusion rates associated with the TPR experiments. The hold period allows the reduction kinetics to equilibrate, and results in the formation of more defined peaks. 
Figure 36 illustrates the TPR-XRD data collected for $\mathrm{BaNi}_{0.4} \mathrm{Al}_{11.6} \mathrm{O}_{18.8}$ [75] from $25-45^{\circ}$ in $2 \theta$.

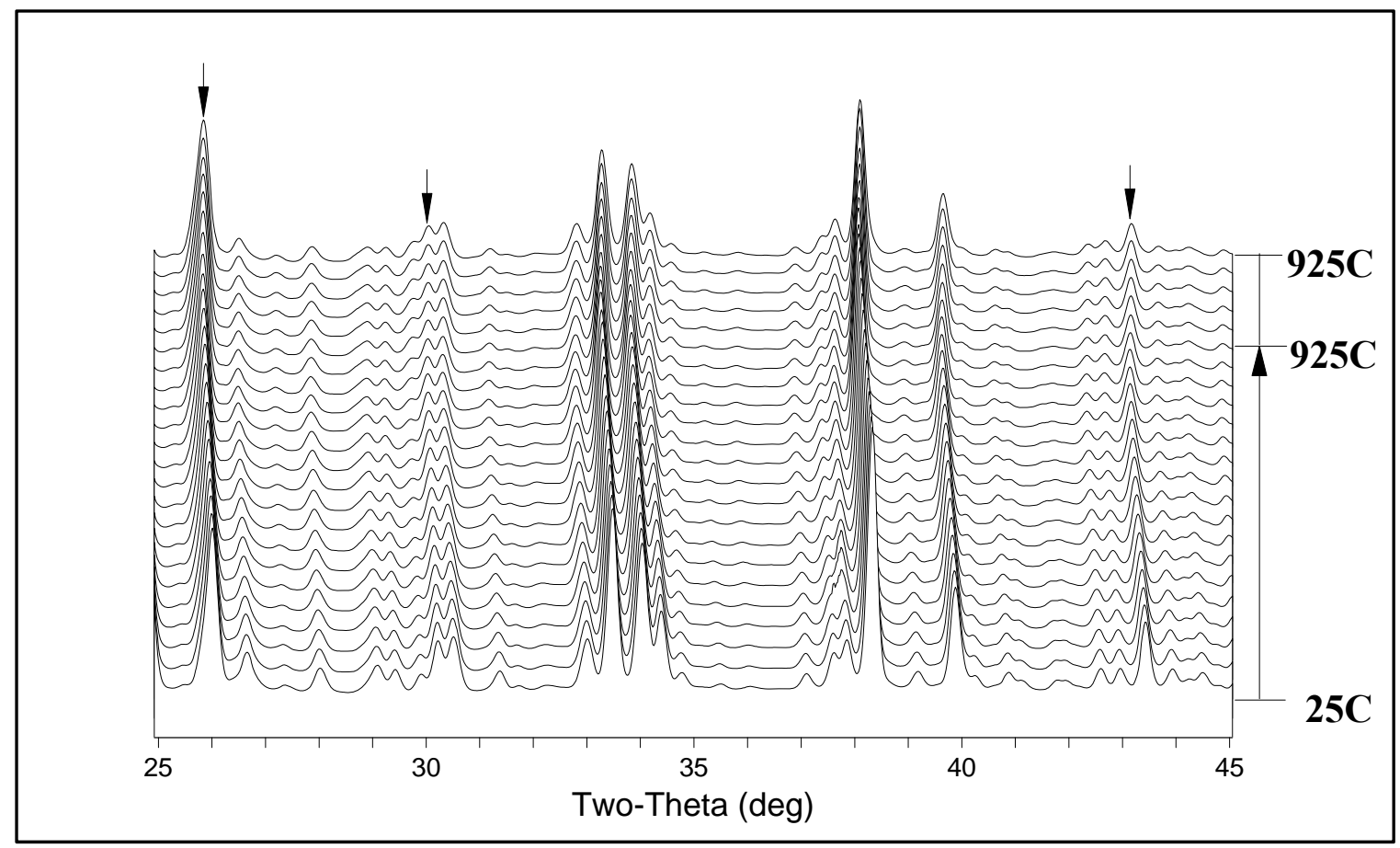

Figure 37: TPR-XRD of $\mathrm{BaNi}_{0.4} \mathrm{Al}_{11.6} \mathrm{O}_{18.8}$ [75] from $25-45^{\circ}$ in $2 \theta$

As shown in Figure 36, there are very strong peaks near the areas where $\mathrm{Ni}^{0}$ metal peaks appear. However, these peaks are attributed to the hexaaluminate structure of the $\mathrm{Ba}$ samples and are of a much higher intensity than $\mathrm{Ni}^{0}$ metal peaks. Due to the masking effect of the Ni-substituted $\mathrm{Ba}$ hexaaluminate structure, there is little to no evidence of $\mathrm{Ni}^{0}$ peak formation in these figures. However, when looking at the results of Ba samples with higher concentrations of $\mathrm{Ni}$ substitution there is a formation of a weak $\mathrm{Ni}^{0}$ peak that appears.

Figure 37 examines the data from the $\mathrm{BaNiAl}_{11} \mathrm{O}_{18.5}[119 \mathrm{~B}]$ sample, which has a peak formation at $30.3^{\circ}$ in $2 \theta$. Although the $\mathrm{Ni}^{0}$ peaks at $26.2^{\circ}$ and $43.5^{\circ}$ in $2 \theta$ are masked by the more intense $\mathrm{Ba}$ hexaaluminate peaks, there is a shoulder peak that forms at approximately $30.3^{\circ}$ in $2 \theta$ and bridges two adjacent peaks. 


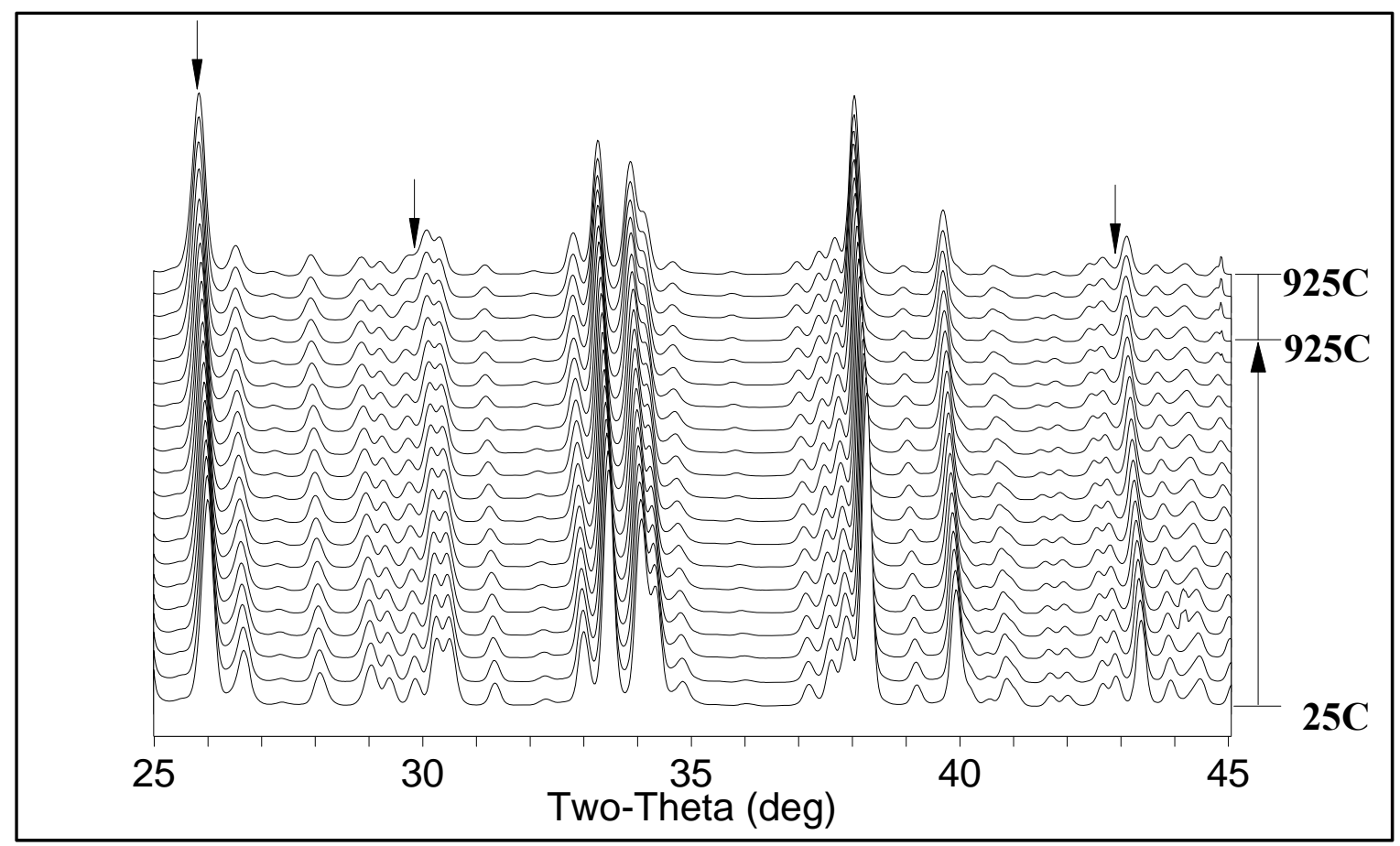

Figure 38: TPR-XRD of $\mathrm{BaNiAl}_{11} \mathrm{O}_{18.5}[119 \mathrm{~B}]$ from $25-45^{\circ}$ in $2 \theta$

Figure 38 allows a closer inspection of the peak $30.3^{\circ}$ in $2 \theta$.

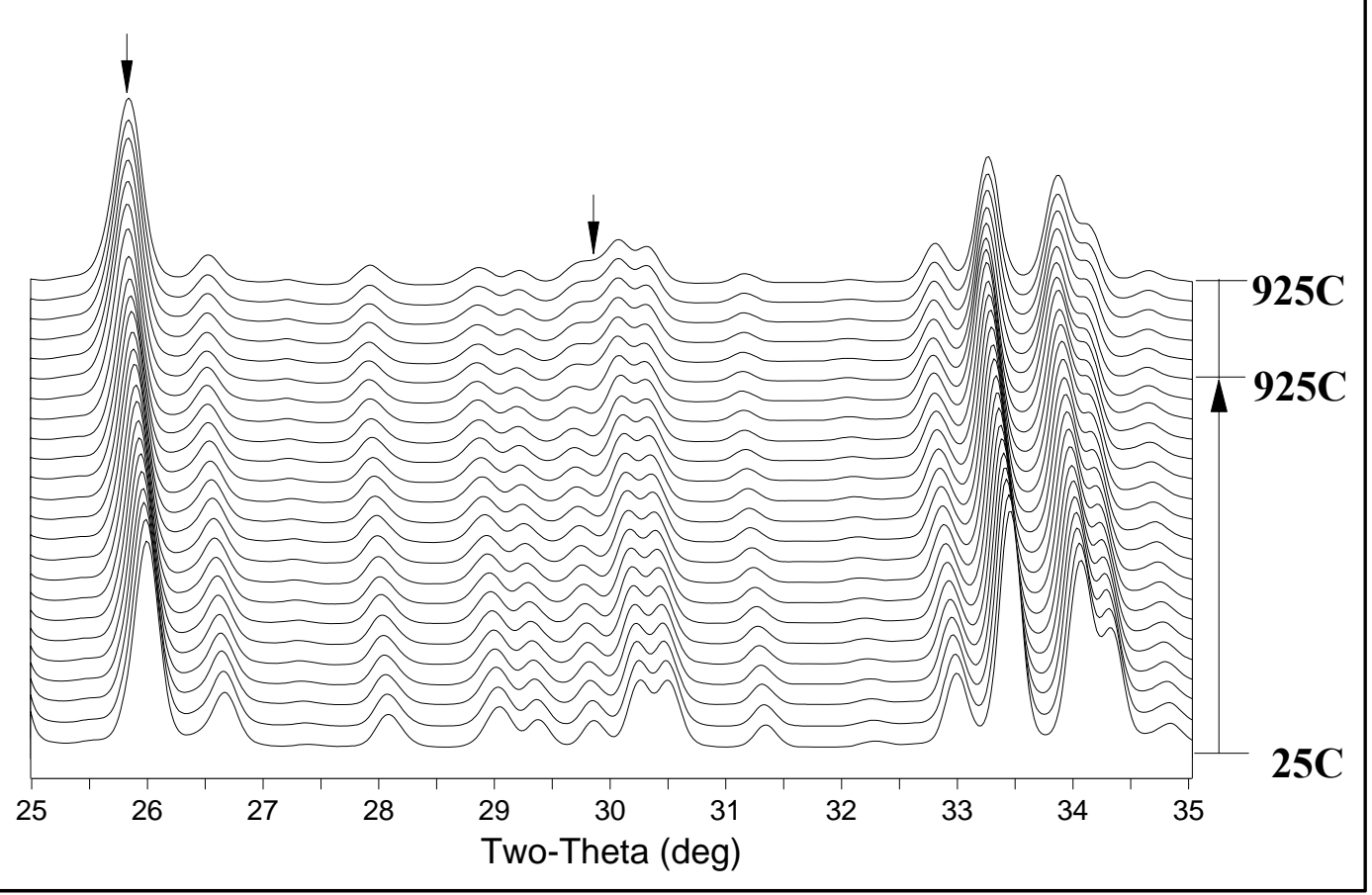

Figure 39: Detail of TPR-XRD of $\mathrm{BaNiAl}_{11} \mathrm{O}_{18.5}[119 \mathrm{~B}]$ from $25-35^{\circ}$ in $2 \theta$ 
The area around $30.3^{\circ}$ at $25^{\circ} \mathrm{C}$ has a low gap with a small peak on its left side and a medium-sized double peak on the right. At this same point at $925^{\circ} \mathrm{C}$, the gap has been filled by the presence of $\mathrm{Ni}^{0}$ metal peak bridging the adjacent hexaaluminate peaks.

Although a peak attributed to the $\mathrm{Ni}^{0}$ peak around $30.3^{\circ}$ in $2 \theta$ for $\mathrm{BaNiAl}_{11} \mathrm{O}_{18.5}$ [119B] has appeared, the TPR-XRD data for the Ba series of hexaaluminates is largely inconclusive. The hexaaluminate structure of $\mathrm{Ba}$ has large peaks in the same positions as $\mathrm{Ni}^{0}$ metal. Due to the low concentration of $\mathrm{Ni}$ in the lattice, the hexaaluminate peaks have a much higher intensity than the Ni and dwarf their presence. This is an unfortunate consequence of the unit-cell size for Ba hexaaluminate. Due to the peak overlapping with the Ba hexaaluminate samples, the TPR-XRD results will be combined with other surface characterization techniques to conclusively determine the presence of $\mathrm{Ni}^{0}$ metal in the surface of the hexaaluminate samples. The XANES and EXAFS analysis is being performed at LSU and the results of FT-IR analysis are presented in Section 4.3.

\subsection{In Situ FT-IR}

To optimize the FT-IR measurement conditions characterization techniques of TPR with $5 \% \mathrm{H}_{2}$ followed by $\mathrm{CO}$ pulse chemisorption were conducted on the samples as described in Section 3.3. Small quantities of $\mathrm{CO}$ were absorbed on each catalyst and there are very low amounts of active $\mathrm{Ni}^{0}$ metal on the surfaces of the hexaaluminates. The results of $\mathrm{CO}$ pulse chemisorptions of $\mathrm{Ni}^{0}$ metal are presented in Table 8 .

Table 8: Results of CO Pulse Chemisorptions of $\mathrm{Ni}^{0}$ Metal in La, $\mathrm{Sr}$ and $\mathrm{Ba} \mathrm{Ni}$ substituted Hexaaluminates

\begin{tabular}{|c|c|c|c|}
\hline $\begin{array}{c}\text { Sample Name } \\
\text { ID\# }\end{array}$ & $\begin{array}{c}\mathrm{Ni}^{0} \text { Dispersion } \\
(\%)\end{array}$ & $\begin{array}{c}\mathrm{Ni}^{0} \text { Surface Area } \\
\left(\mathrm{m}^{2} / \mathrm{g} \text { sample }\right)\end{array}$ & $\begin{array}{c}\mathrm{Ni}^{0} \text { Surface Area } \\
\quad\left(\mathrm{m}^{2} / \mathrm{g} \text { metal }\right)\end{array}$ \\
\hline $\begin{array}{c}\mathrm{LaNi}_{0.4} \mathrm{Al}_{11.6} \mathrm{O}_{19} \\
{[35]}\end{array}$ & 0.0198 & 0.0040 & 0.1317 \\
\hline $\begin{array}{c}\mathrm{SrNi}_{0.4} \mathrm{Al}_{11.6} \mathrm{O}_{19} \\
{[52]}\end{array}$ & 0.0149 & 0.0030 & 0.0993 \\
\hline $\begin{array}{c}\mathrm{BaNi}_{0.4} \mathrm{Al}_{11.6} \mathrm{O}_{18.8} \\
{[75]}\end{array}$ & 0.0204 & 0.0041 & 0.1358 \\
\hline
\end{tabular}

In situ FT-IR spectroscopy study allows for the differentiation of $\mathrm{CO}$ molecules adsorbed on $\mathrm{Ni}$ ions and on $\mathrm{Ni}^{0}$ metal on the surface of the active catalyst, as the position 
of the bands in the infrared spectrum indicates whether the $\mathrm{CO}$ has absorbed on a metal or metal-ion. The peaks observed after exposure of $\mathrm{CO}$ were also analyzed to identify the presence of other species. Table 9 lists the wavenumber values for adsorbed and gas phase $\mathrm{CO}$ molecules.

Table 9: Position of Infrared Bands for CO on Adsorbed Ni Species

\begin{tabular}{|c|c|}
\hline Adsorption Site & Wavenumber, $\mathbf{~ c m}^{-\mathbf{1}}$ (Ref.) \\
\hline $\mathrm{CO}$ on $\mathrm{Ni}^{+2}$ & $2180(32 ; 33 ; 34)$ \\
\hline $\mathrm{CO}$ on $\mathrm{Ni}^{0}$ & $2082(32 ; 34)$ \\
\hline $\mathrm{CO}$ on $\mathrm{Ni}^{0}$ & $2060(32 ; 33 ; 34)$ \\
\hline $\mathrm{CO}$ on $\mathrm{Ni}^{0}$ & $1950(32 ; 33 ; 34)$ \\
\hline
\end{tabular}

According to Kubelkova et al. (32), the adsorption of $\mathrm{CO}$ on $\mathrm{Ni} / \mathrm{Al}_{2} \mathrm{O}_{3}$ at low pressures has two bands, at $1950 \mathrm{~cm}^{-1}$ and $2060 \mathrm{~cm}^{-1}$, which are attributed to the stretching vibrations of $\mathrm{CO}$ in bridged $\mathrm{Ni}-(\mathrm{CO})-\mathrm{Ni}$ and on-top $\mathrm{Ni}-\mathrm{CO}$ complexes on $\mathrm{Ni}^{0}$ metal surfaces respectively. In experiments with increasing pressure, two bands proportional to each other at $2082 \mathrm{~cm}^{-1}$ and $2180 \mathrm{~cm}^{-1}$ are observed. The peak at $2082 \mathrm{~cm}^{-1}$ is also attributed to on-top $\mathrm{Ni}^{0}$ metal clusters, and the peak at $2180 \mathrm{~cm}^{-1}$ is assigned to $\mathrm{CO}$ adsorbed on $\mathrm{Ni}^{+2}$ ions (32). Carbon monoxide is visible in its gas phase as a doublet at a wavenumber of $2143 \mathrm{~cm}^{-1}$ (34).

Table 10 lists the expected assignments of absorption peaks for gases and compounds that appear on the hexaaluminate surfaces.

Table 10: Position of Infrared Bands for CO on Adsorbed Non-Ni Species

\begin{tabular}{|c|c|}
\hline Adsorption Site & Wavenumber $\left.\mathbf{( c m}^{-1}\right)$ \\
\hline $\mathrm{CO}_{2}$ gas phase & $2359,2311(34)$ \\
\hline $\mathrm{CO}$ gas phase & $2143(34)$ \\
\hline Carboxylate, $\mathrm{CO}_{2}$ & $1630-1560(34)$ \\
\hline Monodentate carbonate & $1530-1470(34)$ \\
\hline$v_{\mathrm{as}} \mathrm{COO}^{-}$ & $1420-1350(34)$ \\
\hline
\end{tabular}

The double peak at $2359 \mathrm{~cm}^{-1}$ is attributed to gas phase $\mathrm{CO}_{2}$ and the double peak at 2143 $\mathrm{cm}^{-1}$ is accredited to gas phase CO (34). There are three peaks at $1650 \mathrm{~cm}^{-1}, 1525 \mathrm{~cm}^{-1}$ and $1380 \mathrm{~cm}^{-1}$ that are attributed to surface carbonate-carboxylate compounds (34). 
FT-IR experiments were conducted on all eight of the Ni-substituted hexaaluminate samples. The non-substituted sample, $\mathrm{BaAl}_{12} \mathrm{O}_{19}[38 \mathrm{C}]$, was also included for comparison measurements. The experimental procedure is as described in Section 3.4. Scans were taken after 2, 5, 10, 15, 20, 25 and 30 min of exposure to CO. After 30 min, the chamber was evacuated via a mechanical pump and scans were taken at 5, 10 and 15 min after evacuation to determine what species remain bonded to the surface of the catalysts.

Figure 39 presents spectra of $\mathrm{LaNi}_{0.4} \mathrm{Al}_{11.6} \mathrm{O}_{19}$ [35] during $\mathrm{CO}$ exposure and after chamber evacuation. There are a number of peaks visible in the spectrum; however, there are no peaks observed at $2180 \mathrm{~cm}^{-1}$ or in the range of $1950 \mathrm{~cm}^{-1}$ to $2080 \mathrm{~cm}^{-1}$. Therefore $\mathrm{CO}$ was not found to adsorb on $\mathrm{Ni}^{+2}$ ions or on $\mathrm{Ni}^{0}$ metal. From $3750 \mathrm{~cm}^{-1}$ to $2700 \mathrm{~cm}^{-1}$, there is a large broad peak attributed to $\mathrm{CO}$ interacting with $\mathrm{OH}$ species on the hexaaluminate surface (34). There are two doublets that form near wavenumbers 2359 $\mathrm{cm}^{-1}$ and $2143 \mathrm{~cm}^{-1}$ due to gas phase $\mathrm{CO}_{2}$ and $\mathrm{CO}$. These doublets appear and increase in intensity during the first 10 minutes of exposure and are constant for the remainder of the $30 \mathrm{~min}$ period of exposure to $\mathrm{CO}$.

Upon turning off the flow of $\mathrm{CO}$ and evacuating the system via a mechanical pump, most of the peaks in the $\mathrm{LaNi}_{0.4} \mathrm{Al}_{11.6} \mathrm{O}_{19}$ [35] spectra disappear. As expected, the peaks attributed to gases in the environmental chamber disappeared. The carboxylate peak at $1650 \mathrm{~cm}^{-1}$ is vastly reduced, to approximately one-third of the previous intensity. The carbonate peaks around $1525 \mathrm{~cm}^{-1}$ and $1380 \mathrm{~cm}^{-1}$ are the only peaks that remain at the height they were during $\mathrm{CO}$ exposure.

Similar behavior was observed with the other seven samples of hexaaluminate catalysts. Figure 40 shows the FT-IR spectrum of $\mathrm{SrNi}_{0.4} \mathrm{Al}_{11.6} \mathrm{O}_{19}$ [52] and Figure 41 illustrates the spectrum of $\mathrm{BaNi}_{0.4} \mathrm{Al}_{11.6} \mathrm{O}_{18.8}$ [75]. The spectra of all of the samples have peaks at wavenumbers identical to those observed in the case of $\mathrm{LaNi}_{0.4} \mathrm{Al}_{11.6} \mathrm{O}_{19}$ [35]. The only difference among all of the samples is that the peaks at $1525 \mathrm{~cm}^{-1}$ and $1380 \mathrm{~cm}^{-1}$ have intensities that change depending on which metal carbonate is formed from the varying mirror cations. The carbonate peaks on the $\mathrm{Ba}$ sample were found to have stronger intensities than either $\mathrm{La}$ or $\mathrm{Sr}$. 


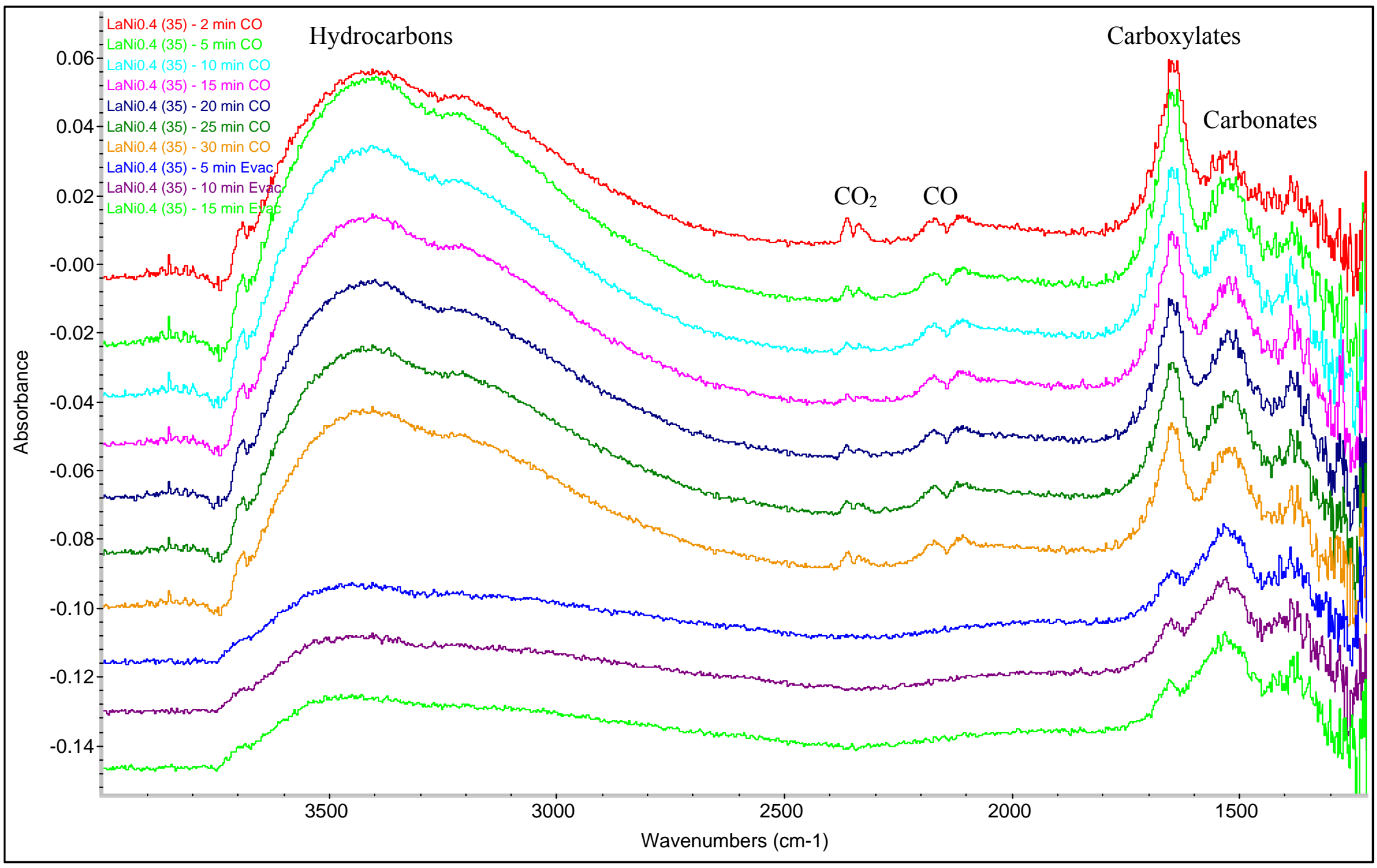

Figure 40: FT-IR spectra of $\mathrm{LaNi}_{0.4} \mathrm{Al}_{11.6} \mathrm{O}_{19}[35]$ after $\mathrm{CO}$ exposure 


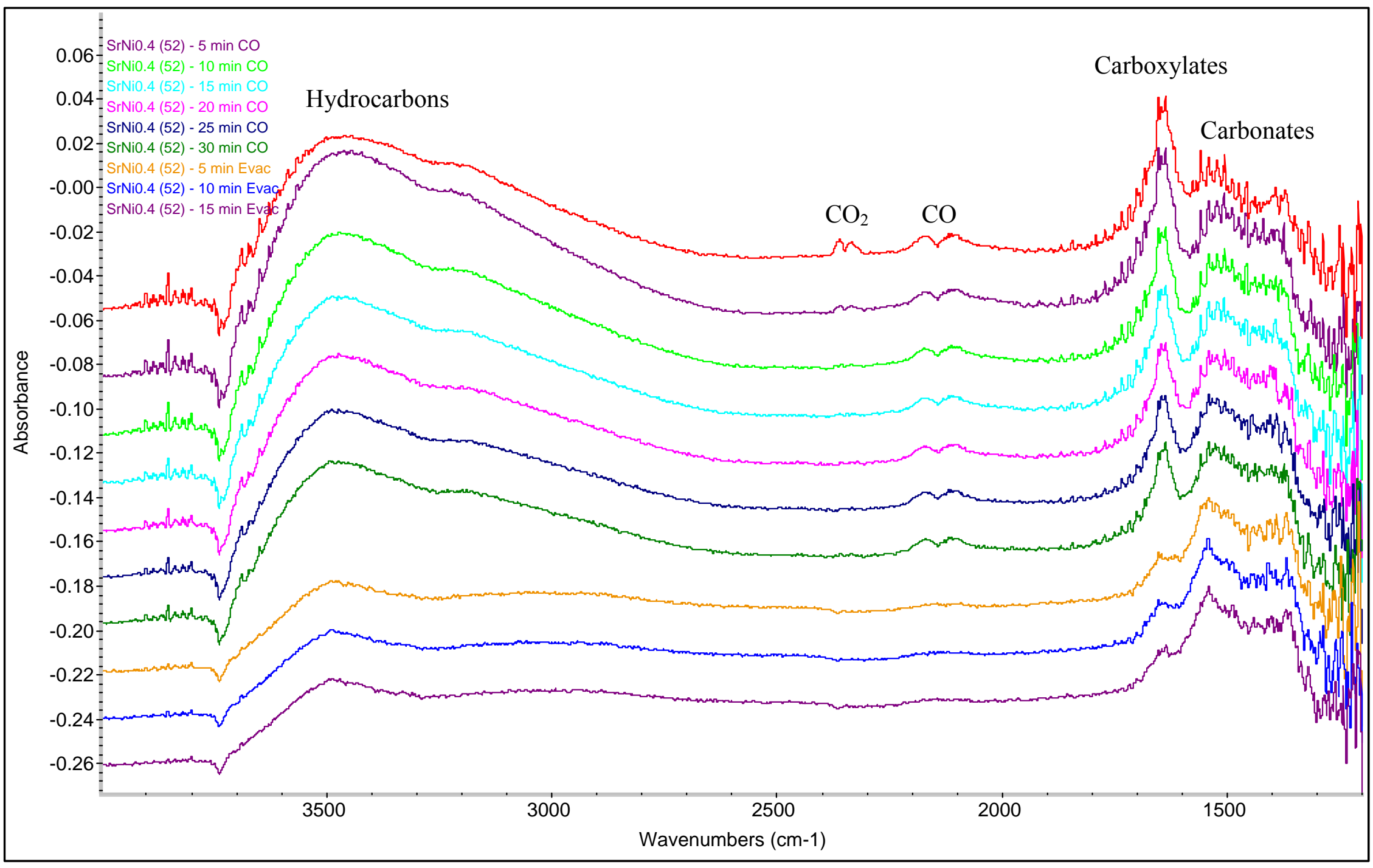

Figure 41: FT-IR spectra of $\mathrm{SrNi}_{0.4} \mathrm{Al}_{11.6} \mathrm{O}_{19}[52]$ after $\mathrm{CO}$ exposure 


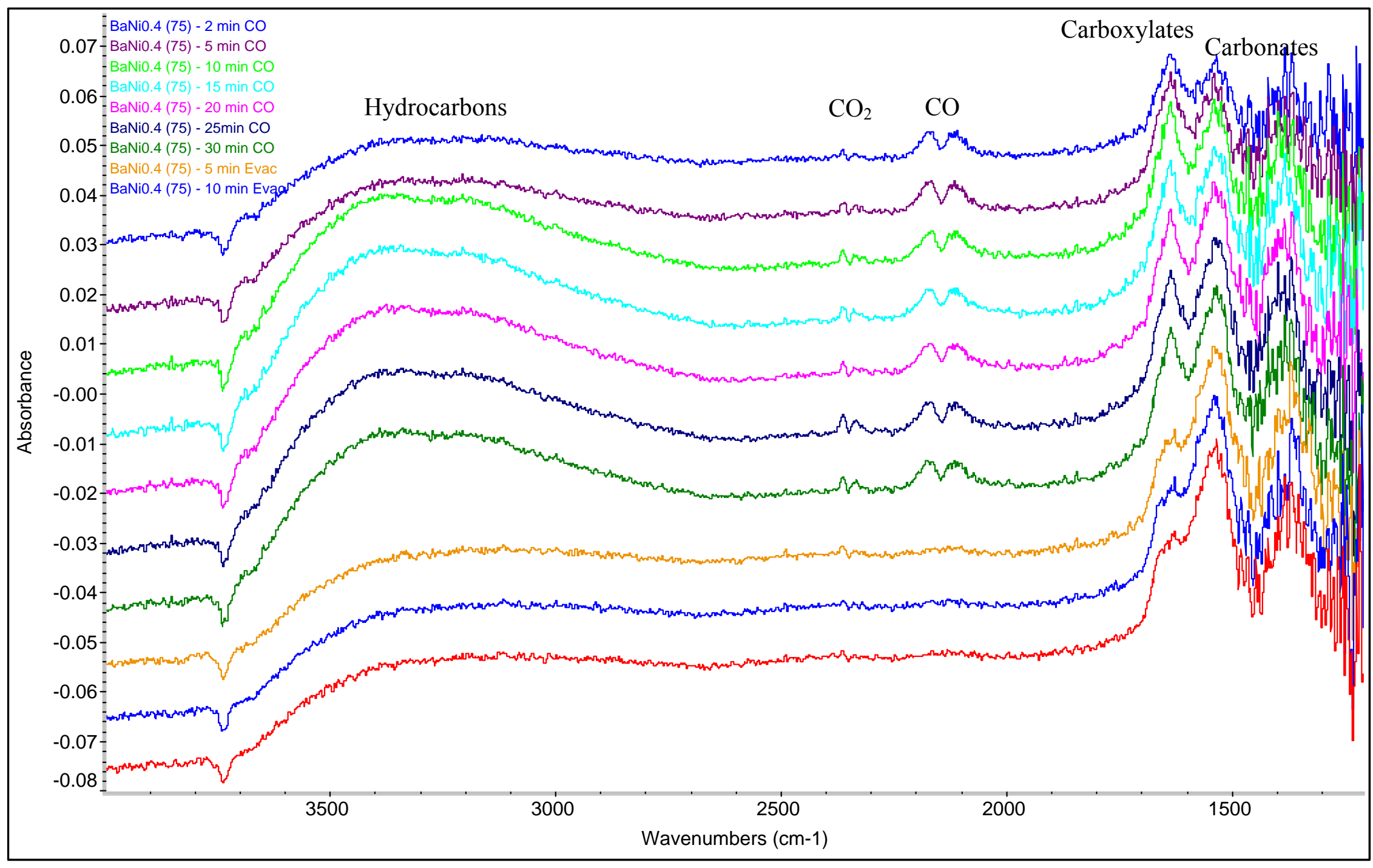

Figure 42: FT-IR spectra of $\mathrm{BaNi}_{0.4} \mathrm{Al}_{11.6} \mathrm{O}_{18.8}[75]$ after $\mathrm{CO}$ exposure 
The only discrepancy from the spectra comes from the $\mathrm{CO}_{2}$ double peak in each hexaaluminate spectra at $2359 \mathrm{~cm}^{-1}$. In both of the $\mathrm{LaNi}_{0.4} \mathrm{Al}_{11.6} \mathrm{O}_{19}$ [35] and $\mathrm{BaNi}_{0.4} \mathrm{Al}_{11.6} \mathrm{O}_{18.8}[75]$ spectra, the peaks appear throughout the entire $\mathrm{CO}$ exposure step, but disappear during evacuation. In the $\mathrm{SrNi}_{0.4} \mathrm{Al}_{11.6} \mathrm{O}_{19}$ [52] spectrum, the $\mathrm{CO}_{2}$ peaks initially appear but quickly diminish and are not observed after $10 \mathrm{~min}$ of exposure to CO. This peculiar behavior suggests that there may be impurities present in the gas source. To test for impurities in the $500 \mathrm{ppm} \mathrm{CO} /$ balance He gas cylinder, FT-IR experiments were conducted on IR inert $\mathrm{KBr}$. It was discovered that undesirable $\mathrm{CO}_{2}$ was indeed present in the $\mathrm{CO} / \mathrm{He}$ gas cylinder and were being introduced into the FT-IR spectra of the hexaaluminates and increase the intensity of the carboxylate and carbonate peaks. A second cylinder composed of $250 \mathrm{ppm} \mathrm{CO} /$ balance He gas mixture was tested and was found to be free of $\mathrm{CO}_{2}$. Each of the samples were re-tested with the $250 \mathrm{ppm}$ $\mathrm{CO} /$ balance He cylinder, however, the FT-IR spectra results were very similar regardless of the pure or impure cylinder source. The only noticeable effect of the $\mathrm{CO}_{2}$ impurity was an enhanced $\mathrm{CO}_{2}$ peak at a wavelength of $2359 \mathrm{~cm}^{-1}$.

The spectra of the Ni-substituted $\mathrm{Ba}$ hexaaluminate series were compared to determine any differences due to differences in Ni composition. The spectrum of $\mathrm{BaNi}_{0.8} \mathrm{Al}_{11.2} \mathrm{O}_{18.6}[118 \mathrm{~B}]$ is shown in Figure 42. The comparison of the spectra of $\mathrm{BaNi}_{0.4} \mathrm{Al}_{11.6} \mathrm{O}_{18.8}$ [75] to that of $\mathrm{BaNi}_{0.8} \mathrm{Al}_{11.2} \mathrm{O}_{18.6}$ [118B] shows a few noticeable differences. There appears to be a slight increase in the peak intensity at a wavenumber of $1525 \mathrm{~cm}^{-1}$ and a moderate increase at $1380 \mathrm{~cm}^{-1}$ with higher Ni substitution. To test the effect of $\mathrm{Ni}$ substitution, the hexaaluminate with zero $\mathrm{Ni}$ composition, $\mathrm{BaAl}_{12} \mathrm{O}_{19}$ [38C], was also analyzed via FT-IR, and the spectra are shown in Figure 43. Comparisons of the spectra of $\mathrm{BaAl}_{12} \mathrm{O}_{19}[38 \mathrm{C}]$ to the spectra of the Ni-substituted hexaaluminates reveal very similar results.

Unit cell refinement and TPR-XRD investigations indicate that $\mathrm{Ni}^{+2}$ ions are reduced to $\mathrm{Ni}^{0}$ metal and form on the surface of the Ni-substituted catalysts. Fourier transform infrared results did not indicate the adsorption of $\mathrm{CO}$ on $\mathrm{Ni}^{0}$ metal or $\mathrm{Ni}^{+2}$ ions. The only species to form on the hexaaluminate surfaces were attributed to various carboxylates and carbonates. The intensity of the carboxylates and carbonates seems to be influenced more by the mirror cation than the presence or substitution level of $\mathrm{Ni}$ in the lattice. However, with the lack of peaks appearing at the $\mathrm{Ni}^{+2}$ ion or $\mathrm{Ni}^{0}$ metal 
wavenumbers, it is difficult to draw any concrete conclusions. There may be other factors that prevent active $\mathrm{Ni}$ sites from being receptive to $\mathrm{CO}$ adsorption on hexaaluminate materials. From reviewing literature and performing the FT-IR experiments, a few potentially flawed reasons are suggested. 


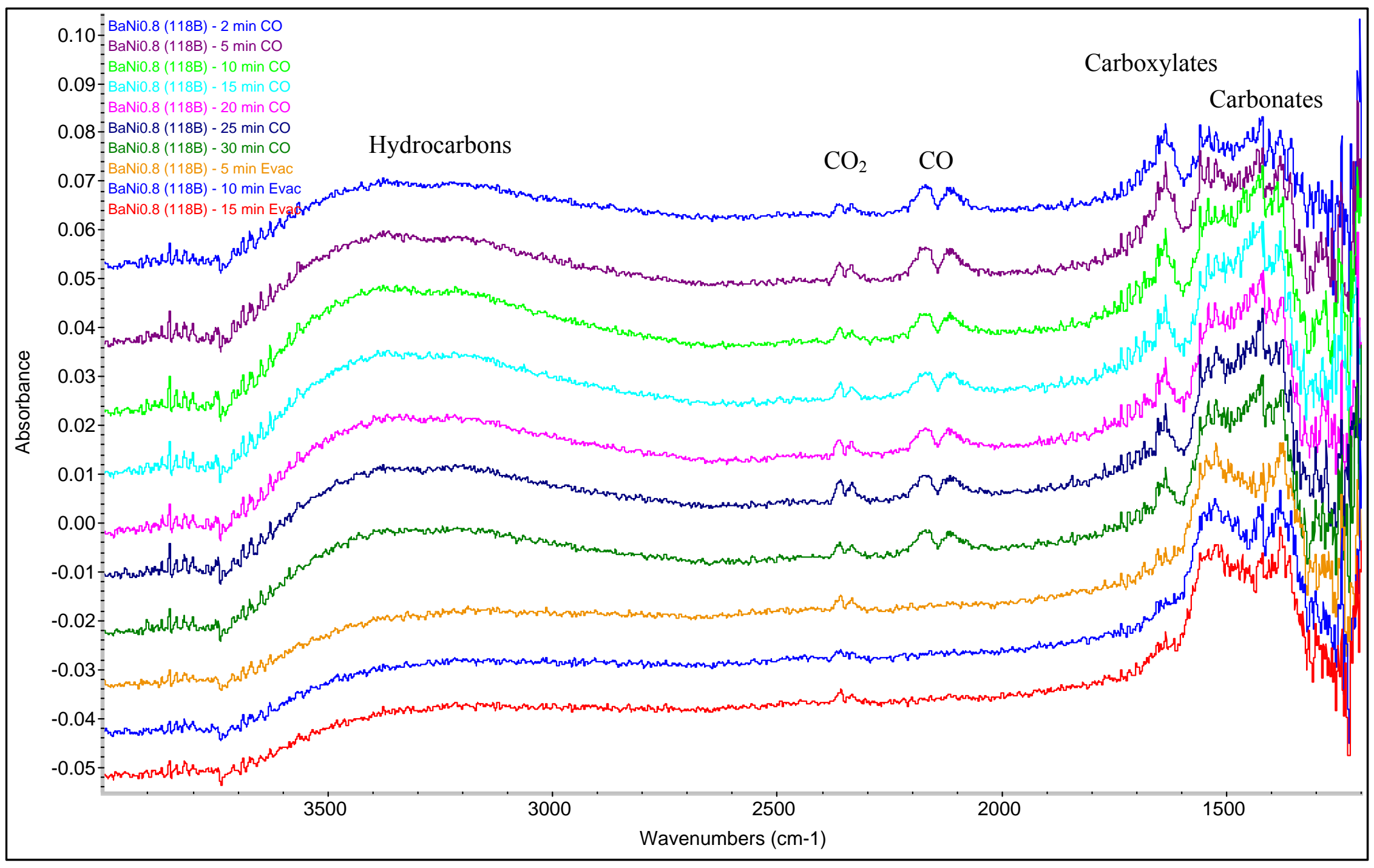

Figure 43: FT-IR spectra of $\mathrm{BaNi}_{0.8} \mathrm{Al}_{11.2} \mathrm{O}_{18.6}[118 \mathrm{~B}]$ after $\mathrm{CO}$ exposure 


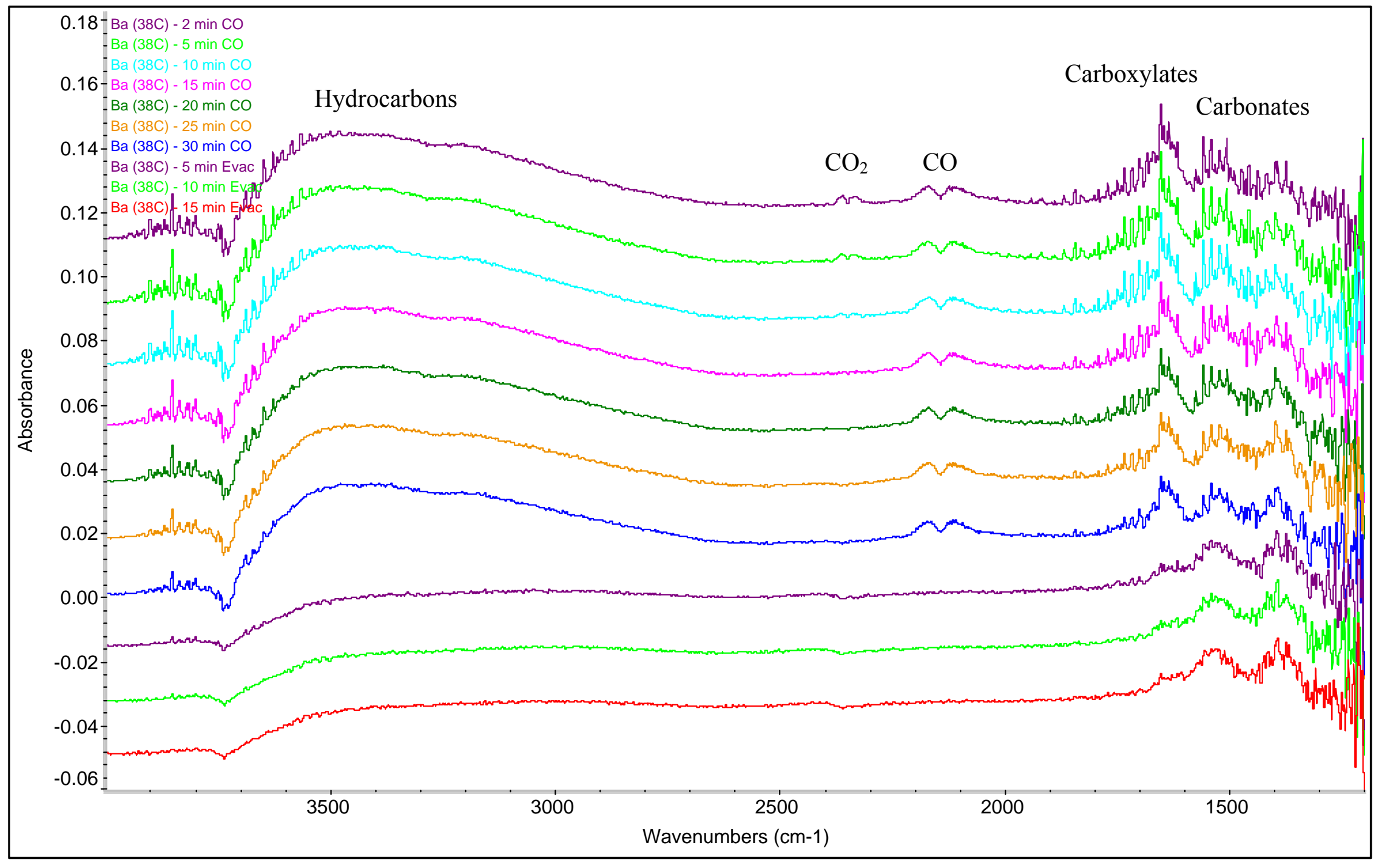

Figure 44: FT-IR spectra of $\mathrm{BaAl}_{12} \mathrm{O}_{19}[38 \mathrm{C}]$ after $\mathrm{CO}$ exposure 
First, strong-metal support interactions (SMSIs) have been shown to suppress the chemisorptive properties of the dispersed metal (35). Traditionally, SMSI occurs in systems where the transition metal oxides have d-orbital electrons or is partially reducible (35). Although alumina does not follow these generalities, Raupp et al. (36) have suggested that, under certain conditions, supports such as alumina could exhibit SMSItype behavior. These interactions may be the reason for the lack of peaks that correspond to $\mathrm{CO}$ molecules adsorbed on either $\mathrm{Ni}^{2+}$ or $\mathrm{Ni}^{0}$.

Second, the DRIFTS environmental chamber cell had several irregularities that made reaching and maintaining the desired temperature difficult. According to the manufacturer's specifications, the cell is capable of reaching temperatures up to $900^{\circ} \mathrm{C}$, which would be ideal for the high reduction temperatures of hexaaluminates. However, the particular unit utilized in this study, even after repairs by the manufacturer, could not consistently reach temperatures above $700^{\circ} \mathrm{C}$, and so experiments were restricted to $600^{\circ} \mathrm{C}$. A passivation technique was implemented in an attempt to circumvent the DRIFTS cell's limitations, but the data did not show any indication of $\mathrm{CO}$ bonding to $\mathrm{Ni}^{+2}$ ions or $\mathrm{Ni}^{0}$ metal. Perhaps new DRIFTS cell or different equipment with no temperature limitations would result in appearances of these desired peaks. 


\section{Chapter 5: Conclusions and Recommendations}

There were two primary objectives under consideration for this project. The first objective was to identify the phase of catalytically active $\mathrm{Ni}$ that has been substituted into the lattice of hexaaluminate catalysts. The second objective was to determine the location of Ni species in the hexaaluminate lattice after synthesis, reduction and reaction. In order to satisfy these objectives, several characterization techniques were applied to investigate the two series of catalysts. Experiments were conducted by means of the following methods: scanning electron microscopy (SEM), unit-cell refinement (UCR), in situ temperature-programmed reduction and X-ray diffraction (TPR-XRD) and Fouriertransform infrared (FT-IR) spectroscopy.

Scanning electron microscopy was used to determine differences in catalyst surface morphology. The SEM images of the mirror-cation-varied samples were found to be very similar in morphology; however there seems to be slight differences on how the particles agglomerate. The $\mathrm{LaNi}_{0.4} \mathrm{Al}_{11.6} \mathrm{O}_{19}$ [35] sample seems to have morphology similar to a coral reef. The $\mathrm{SrNi}_{0.4} \mathrm{Al}_{11.6} \mathrm{O}_{19}$ [52] sample appears to be more like a collection of breakfast-cereal flakes. $\mathrm{BaNi}_{0.4} \mathrm{Al}_{11.6} \mathrm{O}_{18.8}$ [75] has particles that might be described as having the appearance of steamed rice. There appears to be little to no difference between the morphologies of the different Ni-substituted Ba catalysts. They all appear to have agglomerates of hexaaluminate particles, and there is an indication that the percentage of nickel is low enough that variations do not have a substantial effect on surface morphology. Examination of the SEM images could not distinguish any substantial differences between the blue and gray particles of samples taken from TPO experiments with the $\mathrm{POx}$ of $\mathrm{CH}_{4}$.

Unit-cell refinement demonstrates that $\mathrm{Ni}$ has been incorporated into the hexaaluminate lattice during synthesis. Increasing the Ni substitution level results in an increase in the $a$ and $b$ parameters and a decrease in the $c$ direction. The overall volume of the unit-cell was found to increase with higher Ni modification. Upon TPR via $\mathrm{H}_{2}$ and TPO reaction studies of $\mathrm{CH}_{4} \mathrm{POx}$, it was determined that $\mathrm{Ni}^{+2}$ ions are reduced to $\mathrm{Ni}^{0}$ metal and relocate from the lattice via the $a$ and $b$ directions and are heavily involved with catalytic activity of the catalyst. When going from lower to higher Ni substitution the $a$ and $b$ parameters of the fresh samples have a positive slope but there is essentially 
zero slope between the used samples indicating a loss of $\mathrm{Ni}$ from the unit-cell lattices. The $c$ parameters are mostly unchanged from the values of those of the fresh samples and the $c$ dimension is unaffected by the POx reaction. Similar to the behavior of the $a$ and $b$ parameters, while the overall cell volumes of the fresh catalysts increase with $\mathrm{Ni}$ substitution, the post-reaction volumes of the unit-cells shows little to no difference between higher and lower Ni substitution.

In situ TPR-XRD studies with $\mathrm{La}$ and $\mathrm{Sr}$ hexaaluminates show that, upon reduction with $\mathrm{H}_{2}$, $\mathrm{Ni}$ in the lattice turns into metallic $\mathrm{Ni}^{0}$ on the hexaaluminate surface of the crystal. This allows the Ni-substituted hexaaluminate to be an active catalyst for POx of $\mathrm{CH}_{4}$. Experiments with $\mathrm{XRD}$ of $\mathrm{Ba}$ hexaaluminates are mostly inconclusive, due to the hexaaluminate diffraction pattern having intense peaks in the same positions as $\mathrm{Ni}^{0}$ metal so that the hexaaluminate peaks mask the appearance of $\mathrm{Ni}^{0}$ peaks. This is an unfortunate consequence of the unit-cell size for Ba hexaaluminate.

Fourier-transform infrared spectroscopy of the absorption of $\mathrm{CO}$ on reduced catalysts was performed to distinguish between $\mathrm{Ni}^{+2}$ ions and $\mathrm{Ni}^{0}$ metal species on the hexaaluminate surfaces. The analysis of the FT-IR spectra leaves no indication of the presence of $\mathrm{Ni}$ in any form on the surface. Chemisorption of $\mathrm{CO}$ supports the results of FT-IR, in that very low quantities of $\mathrm{CO}$ were adsorbed due to low $\mathrm{Ni}$ dispersion on the hexaaluminate surfaces. The appearance of multiple peaks indicates the presence of $\mathrm{CO}$ and $\mathrm{CO}_{2}$ gas molecules as well as the formation of $\mathrm{La}, \mathrm{Sr}$ and $\mathrm{Ba}$ carboxylates and carbonates. Upon evacuation of the DRIFTS chamber, the only remaining peaks belong to those of the appropriate mirror cation carboxylate-carbonates near $1525 \mathrm{~cm}^{-1}$ and 1380 $\mathrm{cm}^{-1}$.

It is possible that the passivation procedure was not sufficient to keep the catalysts in their reduced state for the FT-IR procedure. It is recommended that future FT-IR investigations should be repeated with a DRIFTS cell or similar apparatus with operating conditions in the $900^{\circ} \mathrm{C}$ to $1100^{\circ} \mathrm{C}$ range to allow for complete reducing conditions. In addition to probing the samples with $\mathrm{CO}$, it is suggested that adsorption of another probe gas, NO, be attempted as well to support or counter the results obtained in this experiment. Other probe gases that are found to be prevalently used in literature include $\mathrm{NO} / \mathrm{O}_{2}$ and $\mathrm{CO} / \mathrm{H}_{2}$ mixtures, but great care should be given if operated at elevated temperatures to avoid the formation of dangerous compounds. 
Additional experimentation in the techniques of XANES and EXAFS are required to obtain a more complete understanding of the nature of active sites present in hexaaluminate catalysts. As part of collaboration with NETL, WVU and LSU, detailed XANES analysis will simultaneously be conducted at LSU by Andrew Campos as part of his $\mathrm{PhD}$ dissertation project. However, this information will be published after the completion of this work and is unavailable at this time. The combination of results from SEM, TPR-XRD, TPR-EXAFS, TPR-XANES and FT-IR characterization techniques will satisfy the goals and objectives of this investigation.

Future work should include further characterization techniques such as in situ electron spectroscopy for chemical analysis (ESCA), scanning tunneling microscopy (STM) and electron-energy loss spectroscopy (EELS). In situ ESCA should be used to examine the possibility of SMSI on hexaaluminate catalysts. Scanning tunneling microscopy can be used to study the atomic surface morphology of oxides as a function of temperature and under reaction conditions (26). Although the images obtained by STM are not a full visual representation of the catalyst surface, information can be determined about the atomic structure at the Fermi energy level. Electron-energy loss spectroscopy can be used in conjunction with XANES and EXAFS techniques to provide information about elemental information, bonding and next nearest neighbor distribution.

Due to the success of TPR-XRD with the La and Sr samples, series of La and Sr hexaaluminates with varying Ni-substitution level could be synthesized. Experiments via UCR and FT-IR could be repeated on these samples to support and/or improve upon the results obtained on the $\mathrm{Ba}$ hexaaluminate series. Alternatively, a series of $\mathrm{Ba}$ hexaaluminates could be created with a different metal dopant than $\mathrm{Ni}$ (Co, Fe, $\mathrm{Mg}$, etc.), and the same characterization techniques performed in this study could be repeated on those samples. 


\section{References}

1. http://www.epa.gov/smartwaylogistics/idle-questions.htm.

2. Stodolsky, F., Gaines, L. and Vyas, A., "Analysis of Technology Options to Reduce the Fuel Consumption of Idling Trucks," Center for Transportation Research, Argonne National Laboratory, U.S. Department of Energy, (2000) P. 1-28.

3. Jain, S., Chen, H-Y. and Schwank, J., s.l. "Techno-economic analysis of fuel cell auziliary power units as alternative to idling," Elsevier, Journal of Power Sources, (2006) Vol. 160, P. 474-484.

4. Storey, J. M., Thomas, J. F., Lewis, S. A., Dam, T. Q., Edwards, K. D., DeVault, G. L., Retrossa, D. J., "Particulate Matter and Aldehyde Emissions From Idling HeavyDuty Diesel Trucks," Department of Energy, Oak Ridge National Laboratory, Society of Automotive Engineers, (2003) P. 1-10.

5. http://www.netl.doe.gov/technologies/coalpower/fuelcells/seca/.

6. Gardner, T. H., Hexaaluminate Catalysts for the Partial Oxidation of Middle Distillate Fuels, Dissertation, Morgantown, West Virginia University, (2007) P. 1138.

7. Machida, M., Eguchi, K., Arai, H., "Effect of Additives on the Surface-Area of Oxide Supports for Catalytic Combustion," Journal of Catalysis, (1987) Vol. 103, P. 385-393.

8. Machida, M., Eguchi, K., Arai, H., "Preparation and Characterization of LargeSurface-Area $\mathrm{BaO}^{*} 6 \mathrm{Al}_{2} \mathrm{O}_{3}$," Bulletin of the Chemical Society of Japan, (1988) Vol. 61, P. 3659-3665.

9. Xu, Z., Zhen, M., Bi, Y., Zhen, K., "Carbon Dioxide Reforming of Methane to Synthesis Gas Over Hexaaluminate $\mathrm{ANiAl}_{11} \mathrm{O}_{19-\delta}(\mathrm{A}=\mathrm{Ca}, \mathrm{Sr}, \mathrm{Ba}$ and $\mathrm{La})$ Catalysts," Catalysis Letters, (2000) Vol. 64, P. 157-161.

10. Xu, Z., Zhen, M., Bi, Y., Zhen, K., "Catalytic Properties of Ni Modified Hexaaluminates $\mathrm{LaNi}_{\mathrm{y}} \mathrm{Al}_{12-\mathrm{y}} \mathrm{O}_{19-\delta}$ for $\mathrm{CO}_{2}$ Reforming of Methane to Synthesis Gas," Applied Catalysis A: General, (2000) Vol. 198, P. 267-273.

11. Machida, M., Eguchi, K., Arai, H., "Catalytic Properties of $\mathrm{BaMAl}_{11} \mathrm{O}_{19-\alpha}(\mathrm{M}=\mathrm{Cr}$, $\mathrm{Mn}, \mathrm{Fe}, \mathrm{Co}$, and Ni) for High-Temperature Catalytic Combustion," Journal of Catalysis, (1989) Vol. 120, P. 377-386.

12. Park, J-G., Cormack, A. N., "Crystal/Defect Structures and Phase Stability in Ba Hexaaluminates," Journal of Solid State Chemistry, (1996) Vol. 121, P. 278-290. 
13. Kimura, S., Banai, E., Shindo, I., "Phase Relations Relevant to Hexagonal Barium Aluminates," Materials Research Bulletin, (1981)Vol. 17, P. 209-215.

14. Iyi, N, Takekawa, S. and Bando, Y., Kimura, S., "Electron Microscopic Study of Barium Hexaaluminates," Journal of Solid State Chemistry, (1983)Vol. 47, P. 34-40.

15. Iyi, N., Inoue, Z., Takekawa, S., Kimura, S., "The Crystal Structure of Barium Hexaaluminate Phase I (Barium $\beta$-Alumina)," Journal of Solid State Chemistry, (1983) Vol. 52, P. 66-72.

16. Chu, W., Yang, W., Lin, L., "The Partial Oxidation of Methane to Syngas Over the Nickel-Modified Hexaaluminate Catalysts $\mathrm{BaNi}_{\mathrm{y}} \mathrm{Al}_{12-\mathrm{y}} \mathrm{O}_{19-\delta}$," Applied Catalysis A: General, (2002) Vol. 235, P. 39-45.

17. Lietti, L., Cristiani, C., Groppi, G., Forzatti, P., "Preparation, Characterization and Reactivity of Me-Hexaaluminate ( $\mathrm{Me}=\mathrm{Mn}, \mathrm{Co}, \mathrm{Fe}, \mathrm{Ni}, \mathrm{Cr}$ ) Catalysts in the Catalytic Combustion of $\mathrm{NH}_{3}$-Containing Gasified Biomasses," Catalysis Today, (2000) Vol. 59, P. 191-204.

18. Gardner, T. H., Shekhuwat, D., Berry, D. A., Smith, M. W., Salazar, M., Kugler, E. L., "Effect of Nickel Hexaaluminate Mirror Cation on Structure-Sensitive Reactions During n-tetradecane Parial Oxidation," Applied Catalysis A: General, (2007) Vol. 323, P. 1-8.

19. Machida, M., Eguchi, K., Arai, H., "Analytical Electron Microscope Analysis of the Formation of $\mathrm{BaO}^{*} 6 \mathrm{Al}_{2} \mathrm{O}_{3}$," Journal of American Cermaic Society, (1988) Vol. 71, P. 1142-1147.

20. Chu, W., Yang, W., Lin, L., "Selective Oxidation of Methane to Syngas Over NiO/Barium Hexaaluminate," Catalysis Letters, (2001) Vol. 74, P. 139-144.

21. Gardner, T., Kugler, E., and Spivey, J., "Hexaaluminates as Efficient Partial Oxidation Catalysts," May 2007 Monthly Report, (2007), P. 1-19.

22. Bukhtiyarova, M. V., Ivanova, A. S., Plyasova, L., Litvak, G. S., Budneva, A. A., Paukshtis, E. A., "Structure and Acid-Base Properties of Hexaaluminates," Reaction Kinetics Catalysis Letters (2008) Vol. 93, Iss. 2, P. 375-387.

23. Holland, T.J.B., and Redfern, S.A.T., "Unit Cell Refinement from Powder Diffraction Data: The Use of Regression Diagnostics," Mineralogical Magazine (1997) Vol. 61, P. 65-77.

24. Norby, P., Hanson, J.C., "Hydrothermal Synthesis of the Microporous Aluminophosphate CoAPO-5; In Situ Time-Resolved Synchrotron X-ray Powder Diffraction Studies," Catalysis Today, (1998) Vol. 39, P. 301-309. 
25. Machida, M., Shiomitsu, T., Eguchi, K., Arai, H., Shimizu, Y., "Observation of Anisotropic Oxygen Diffusion in Hexaaluminate," Journal of Solid State Chemistry, (1991) Vol. 95, P. 220-223

26. Fernandez-Garcia, M., Martinez-Arias, A., Hanson, J.C., and Rodriguez, J.A., "Nanostructured Oxides in Chemistry; Characterization and Properties," Chemistry Review, (2004) Vol. 104, P. 4063-4104.

27. Norby, P., "Synchrotron Powder Diffraction using Imaging Plates: Crystal Structure Determination and Rietveld Refinement," Journal of Applied Crystallography, (1997) Vol. 30, P. 21-30.

28. Galuszka, J., and Amenomiya, Y., "Infrared Study of Coadsorption of $\mathrm{CO}$ and $\mathrm{H}_{2}$ on Alumina-supported Nickel Catalysts," Catalysis on the Energy Scene, (1984) Vol. unknown, P. 63-70.

29. Bengaard, H. S., Norskov, J. K., Sehested, J., Clausen, B. S., Nielsen, L. P., Molenbroek, A. M., Rostrup-Nielsen, J. R., "Steam Reforming and Graphite Formation on Ni Catalysts," Journal of Catalysis, (2002) Vol. 209, P. 365-384.

30. Kantcheva, M., Agiral, A, Samarskaya, O., Stranzenbach, M., and Saruhan, B., "Characterization of $\mathrm{LaMnAl}_{11} \mathrm{O}_{19}$ by FT-IR Spectroscopy of Adsorbed NO and $\mathrm{NO} / \mathrm{O}_{2}$," Applied Surface Science, (2005) Vol. 252, P. 1481-1491.

31. Hu, C., Chen, Y., Li, P., Min, H., Chen, Y., and Tian, A., "TemperatureProgrammed FT-IR Study of the Adsorption of $\mathrm{CO}$ and Co-adsorption of $\mathrm{CO}$ and $\mathrm{H}_{2}$ on $\mathrm{Ni} / \mathrm{Al}_{2} \mathrm{O}_{3}$," Journal of Molecular Catalysis A: Chemical, (1996) Vol. 110, P. 163169.

32. Kubelkova, L., and Novakova, J., "Characterization of Nickel Species at $\mathrm{Ni} / \gamma-\mathrm{Al}_{2} \mathrm{O}_{2}$ and $\mathrm{Ni}$ /faujasite Catalysts by Carbon Monoxide Adsorption," Applied Catalysis A: General, (1993) Vol. 95, P. 87-101.

33. Peri, J.B., "Infrared Studies of Ni Held at Low Concentrations on Alumina Supports," Journal of Catalysis, (1984) Vol. 86, P. 84-94.

34. Davydov, A., Molecular Spectroscopy of Oxide Catalyst Surfaces, Chichester, West Sussex, England, John Wiley \& Sons, (2003) P. 135, 271.

35. Huang, Y.J., and Baltrus, J.P., "Effect of Catalyst Preparation on Catalytic Activity VII. The Chemical Structures on Nickel/Alumina Catalysts: Their Impact on the Formation of Metal-Support Interactions," Applied Catalysis, (1988) Vol. 37, P. 229-245.

36. Raupp, G.B., Dumesic, J.A., "Effect of Varying Titania Surface Coverage of the Chemisorptive Behavior of Nickel," Journal of Catalysis, (1985) Vol. 95, P. 587601. 


\section{Appendix}

\section{A.1 Procedure for FT-IR Experiments}

1. Grind sample in mortar and pestle to fine powder. Load sample into ceramic cup of DRIFTS Chamber \#2 until there is a flat surface even to the lip of the cup.

2. Using vacuum grease, rub a very thin layer around large O-ring and place in designated groove around the cup. Place lid on the chamber and tighten the screws in place to seal the chamber.

3. Repeat Steps 1,2 in DRIFTS Chamber \#1 with separate sample or $\mathrm{KBr}$ standard to ensure even flow across both chambers.

4. Take DRIFTS cell and attach inlet and outlet lines of water cooling system and test for leaking. If leaking occurs, repeat previous Step 2 on leaky chamber until no leaks occur.

5. Place DRIFTS cell into Smart Collector and slide to chosen position (scanning Chamber 1 or 2).

6. Attach gas inlet and outlet lines to DRIFTS cell.

7. Turn on control system for mass flow controllers and set desired flow of $5 \% \mathrm{H}_{2}-95 \%$ He gas. Test gas lines for leaks with leak detection bubble solution.

8. Attach heater cable and thermocouple lines of DRIFTS cell to heater controller. Turn on heater control system and set desired program.

9. Run program to reduce samples and monitor system until program is completed.

10. If using $\mathrm{MCT} / \mathrm{A}$ detector $\left(\mathrm{CaF}_{2}\right)$, the detector reservoir needs to be filled with liquid $\mathrm{N}_{2} 30$ min prior to the end of the program. Refill liquid $\mathrm{N}_{2}$ as needed to keep detector cool.

11. Allow sample to cool to $25^{\circ} \mathrm{C}$. Turn off flow of $5 \% \mathrm{H}_{2}-95 \% \mathrm{He}$ gas. Turn on mechanical pump to evacuate system.

12. Enable power to the Nexus spectrometer.

13. After spectrometer is running, turn on power to computer.

14. Open Omnic software on computer.

15. Allow software to perform diagnostic tests on spectrometer and accessories. 
16. Select Nexus Smart Collector Experiment program. Click on Collect» Experiment Setup to view/change scanning parameters.
a. No. of scans: 128
b. Resolution: $4 \mathrm{~cm}^{-1}$
c. Detector: $\mathrm{MCT} / \mathrm{A}$
d. Max range limit: $4000 \mathrm{~cm}^{-1}$
e. Min range limit: $1200 \mathrm{~cm}^{-1}$
f. Gain: Autogain
g. Velocity: 1.8988
h. Aperture: 32

17. Click icon to Collect Background to take background scan of sample.

18. Turn off mechanical pump. Turn on flow of 500 ppm CO-balance He gas.

19. Click icon to Collect Sample to take scans at 2, 5, 10, 15, 20, 25 and $30 \mathrm{~min}$ intervals.

20. Upon $30 \mathrm{~min}$ of exposure to $\mathrm{CO}$, turn off flow of gas. Turn on mechanical pump to evacuate system.

21. Click icon to Collect Sample to take scans at 5, 10 and 15 min intervals.

22. End the experiment. Turn off control systems for heating, cooling and mass flow controllers.

23. Shut down computer THEN power down spectrometer.

24. Detach gas, water and heating/thermocouple lines from DRIFTS cell.

25. Open DRIFTS cell chambers and recover samples.

26. Begin preparations for new experiment. 